\title{
BOTSWANA: 2015 ARTICLE IV CONSULTATION-PRESS RELEASE; STAFF REPORT; AND STATEMENT BY THE EXECUTIVE DIRECTOR FOR BOTSWANA
}




\section{INTERNATIONAL MONETARY FUND}

IMF Country Report No. 16/103

\section{BOTSWANA}

\section{ARTICLE IV CONSULTATION-PRESS RELEASE; STAFF REPORT; AND STATEMENT BY THE EXECUTIVE DIRECTOR FOR BOTSWANA}

Under Article IV of the IMF's Articles of Agreement, the IMF holds bilateral discussions with members, usually every year. In the context of the 2015 Article IV consultation with Botswana, the following documents have been released and are included in this package:

- A Press Release summarizing the views of the Executive Board as expressed during its March 16, 2016 consideration of the staff report that concluded the Article IV consultation with Botswana.

- The Staff Report prepared by a staff team of the IMF for the Executive Board's information following discussions that ended December 22, 2015 with the officials of Botswana on economic developments and policies. Based on information available at the time of these discussions, the staff report was completed on March 1, 2016.

- A Statement by the Executive Director for Botswana.

The IMF's transparency policy allows for the deletion of market-sensitive information and premature disclosure of the authorities' policy intentions in published staff reports and other documents.

Copies of this report are available to the public from

International Monetary Fund • Publication Services

PO Box 92780 • Washington, D.C. 20090

Telephone: (202) 623-7430 • Fax: (202) 623-7201

E-mail: publications@imf.org Web: http://www.imf.org

Price: $\$ 18.00$ per printed copy

\section{International Monetary Fund Washington, D.C.}




\section{IMF Executive Board Concludes Article IV Consultation with Botswana}

On March 16, 2016, the Executive Board of the International Monetary Fund (IMF) concluded the Article IV consultation ${ }^{1}$ with Botswana.

After a rapid recovery from the 2009 downturn, GDP growth is estimated to have turned slightly negative in 2015 owing to a decline in the global demand for diamonds and copper. Non-mining activities, while recording positive growth over the year, remained subdued owing to spillovers from lower mining activity, a regional drought, and electricity and water shortages. Inflation has been declining over the past few years and is now close to the lower bound of the Bank of Botswana's objective range of 3-6 percent, reflecting a successful monetary policy, lower fuel prices, and an appreciation of the Pula against the South African Rand.

After three years of surpluses, the government balance has turned into a deficit, reflecting lower mining revenues, a decline in revenues from the South African Customs Union (SACU), and higher fiscal spending, part of which is related to the Government Stimulus Program. The deficit has been financed by drawing on previously accumulated savings and incurring a small amount of domestic debt. The external current account surplus has also been declining, but is estimated to be in positive territory. As Botswana entered the current downturn with large fiscal and foreign reserve buffers, the country is well positioned to deal with the decline in export demand.

A gradual economic recovery is projected in the next three years, based on an expected gradual increase in diamond prices and fiscal stimulus, while inflation is expected to remain within the BoB's objective range. The 2016/17 budget submitted to Parliament in February envisages a fiscal deficit of about 4 percent of GDP as a result of lower mining and SACU revenues and higher capital expenditures. In the medium-term, the macroeconomic framework envisages fiscal consolidation based on a gradual recovery of the mining sector and expenditure rationalization (the authorities plan to contain the growth of wages and salaries and reduce transfers to state-owned enterprises). Lastly, the external current account surplus is projected to

\footnotetext{
${ }^{1}$ Under Article IV of the IMF's Articles of Agreement, the IMF holds bilateral discussions with members, usually every year. A staff team visits the country, collects economic and financial information, and discusses with officials the country's economic developments and policies. On return to headquarters, the staff prepares a report, which forms the basis for discussion by the Executive Board.
} 
narrow further this year, but gradually reverse to trend thereafter along an expected recovery in export prices.

\section{Executive Board Assessment ${ }^{2}$}

Directors commended Botswana's track record of prudent economic policies and sound institutions, which has led to low public debt and sizable fiscal and foreign exchange savings. Directors noted that, with the recent weakening of the global demand for diamonds, the near-term outlook has become more challenging. They concurred that the country is well-positioned to weather the current downturn, and that medium-term prospects are favorable, although subject to downside risks.

Directors supported the currently accommodative macroeconomic policy stance. They noted that the fiscal stimulus, envisaging high levels of public investment, is justified given the negative output gap, strong buffers, and the need to close the infrastructure gap. Nevertheless, in light of implementation and capacity constraints, Directors encouraged the authorities to exercise caution and focus on the most profitable and viable investments.

Directors emphasized that, in the medium term, fiscal consolidation will be important to safeguard fiscal and external stability. In this regard, they welcomed the authorities' commitment to return to fiscal surpluses within the next three years by containing current spending, especially the size of the wage bill and transfers to state-owned enterprises (SOEs). In light of subdued prospects for revenues from the Southern African Customs Union and risks about future diamond receipts, Directors stressed the need to enhance non-mineral revenue mobilization, notably in the areas of value-added-tax collection, tax exemptions, and property taxation. While noting that the fiscal framework has served the authorities well, Directors generally saw merit in considering options to strengthen the framework for managing mineral revenues, including with a view to avoiding pro-cyclicality in public spending.

Directors noted that the financial system remains sound, and welcomed the authorities' intentions to step up monitoring of financial sector risks given the slowing economy. This includes yearly on-site examinations of systemic banks, a stress test to assess households' debt servicing capacity, implementation of Basel II requirements, improvements in access to credit information, and development of a formal macroprudential framework.

\footnotetext{
2 At the conclusion of the discussion, the Managing Director, as Chairman of the Board, summarizes the views of Executive Directors, and this summary is transmitted to the country's authorities. An explanation of any qualifiers used in summings up can be found here: http://www.imf.org/external $/ \mathrm{hp} / \mathrm{sec} / \mathrm{misc} / \mathrm{qualifiers.htm}$.
} 
Directors stressed the importance of moving ahead with structural reforms to strengthen the efficiency of the public sector, promote private sector development, diversify the economy, and lower unemployment in the context of the forthcoming National Development Plan. Priorities include reforms to resolve the energy and water crises and improve the efficiency of SOEs more generally; strengthening the quality and efficiency of public investment by undertaking a Public Investment Management Assessment; implementation of the action plan to improve the business environment; and efforts to improve employment prospects by enhancing training programs and investments in education. Directors also recommended a gradual approach to develop special economic zones in order to contain fiscal costs and avoid unproductive investments. 
Botswana: Selected Economic and Social Indicators, 2012-2016

\begin{tabular}{|c|c|c|c|c|c|}
\hline & \multirow[t]{2}{*}{2012} & \multirow[t]{2}{*}{2013} & \multirow[t]{2}{*}{2014} & 2015 & \multirow{2}{*}{2016} \\
\hline & & & & Prel. & \\
\hline National income and prices & \multicolumn{5}{|c|}{ (Annual percent change, unless otherwise indicated) } \\
\hline Real GDP ${ }^{1}$ & 4.5 & 9.9 & 3.2 & -0.3 & 3.7 \\
\hline Mineral & -5.8 & 24.2 & 0.5 & -21.0 & -3.0 \\
\hline Nonmineral $^{2}$ & 6.4 & 7.4 & 3.7 & 3.6 & 4.7 \\
\hline Consumer prices (average) & 7.5 & 5.9 & 4.4 & 3.0 & 3.4 \\
\hline Diamond production (millions of carats) & 20.9 & 23.0 & 24.7 & 21.7 & 20.8 \\
\hline \multicolumn{6}{|l|}{ External sector } \\
\hline Exports of goods and services, f.o.b. (US\$) & -7.4 & 28.8 & 7.8 & -29.4 & 5.5 \\
\hline Of which: diamonds & 7.1 & 39.0 & 10.4 & -34.4 & 7.7 \\
\hline Imports of goods and services, f.o.b. (US\$) & 7.4 & 3.4 & -4.3 & -20.7 & 13.2 \\
\hline Terms of trade & 18.0 & 29.7 & 8.5 & 1.8 & 12.8 \\
\hline Nominal effective exchange rate & -2.2 & -0.4 & -0.2 & 0.0 & $\ldots$ \\
\hline Real effective exchange rate & 1.0 & 1.6 & 0.4 & 0.6 & $\ldots$ \\
\hline Money and banking & \multicolumn{5}{|c|}{ (Percentage change with respect to $\mathrm{M} 2$ ) } \\
\hline Net foreign assets & 0.2 & 16.8 & 21.2 & 12.5 & 7.1 \\
\hline Net domestic assets & 7.8 & -9.2 & -17.2 & -2.2 & 4.7 \\
\hline Broad money (M2) & 8.4 & 8.4 & 4.6 & 10.5 & 11.3 \\
\hline Velocity (GDP relative to $\mathrm{M} 2$ ) & 2.3 & 2.3 & 2.6 & 2.2 & 2.2 \\
\hline Velocity (nonmineral GDP relative to $M 3$ ) & 1.8 & 1.8 & 1.9 & 1.9 & 1.9 \\
\hline Credit to the private sector & 13.6 & 9.8 & 10.2 & 6.3 & 7.3 \\
\hline Investment and savings $^{1}$ & \multicolumn{5}{|c|}{ (Percent of GDP, unless otherwise indicated) } \\
\hline Gross investment (including change in inventories) & 38.1 & 32.9 & 30.6 & 27.8 & 29.4 \\
\hline 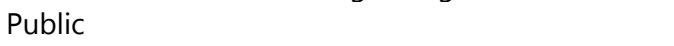 & 7.8 & 7.0 & 8.4 & 10.2 & 9.7 \\
\hline Private & 30.4 & 25.8 & 22.2 & 17.6 & 19.7 \\
\hline Gross savings & 39.6 & 41.8 & 46.3 & 37.1 & 31.6 \\
\hline Public & 20.1 & 21.6 & 23.8 & 22.1 & 18.4 \\
\hline Private & 19.4 & 20.2 & 22.4 & 15.0 & 13.1 \\
\hline Saving-investment balance & 1.4 & 8.9 & 15.6 & 9.3 & 2.2 \\
\hline \multicolumn{6}{|l|}{ Central government finances $^{2}$} \\
\hline Total revenue and grants & 36.2 & 38.0 & 39.6 & 36.8 & 31.3 \\
\hline Total expenditure and net lending & 35.4 & 32.4 & 35.8 & 39.7 & 35.2 \\
\hline Overall balance (deficit -) & 0.8 & 5.6 & 3.8 & -3.0 & -3.9 \\
\hline Non-mineral primary balance ${ }^{3}$ & -13.0 & -13.6 & -16.9 & -20.7 & -19.1 \\
\hline Total central government debt & 18.9 & 17.6 & 17.9 & 17.8 & 15.6 \\
\hline \multicolumn{6}{|l|}{ External sector } \\
\hline Current account balance & 0.3 & 8.9 & 15.7 & 9.3 & 2.2 \\
\hline Balance of payments & -0.8 & 1.1 & 8.0 & 2.4 & 5.1 \\
\hline \multirow[t]{2}{*}{ External public debt ${ }^{4}$} & 19.5 & 12.5 & 10.9 & 11.1 & 9.9 \\
\hline & \multicolumn{5}{|c|}{ (Millions of US\$, unless otherwise indicated) } \\
\hline Gross official reserves (end of period) & 7,617 & 7,768 & 8,313 & 7,500 & 8,142 \\
\hline \multicolumn{6}{|l|}{ Of which: Pula Fund } \\
\hline Months of imports of goods and services ${ }^{5}$ & 10.0 & 10.6 & 14.4 & 11.4 & 11.7 \\
\hline Months of non-diamond imports ${ }^{5}$ & 14.8 & 15.9 & 18.8 & 15.5 & 16.0 \\
\hline Percent of GDP & 52.9 & 54.5 & 55.5 & 64.7 & 64.5 \\
\hline \multicolumn{6}{|c|}{ Sources: Botswana authorities and IMF staff estimates and projections. } \\
\hline \multicolumn{6}{|c|}{${ }^{1}$ Calendar year. } \\
\hline \multicolumn{6}{|l|}{${ }^{2}$ Year beginning April 1.} \\
\hline \multicolumn{6}{|c|}{$\begin{array}{l}3 \text { The non-mineral primary balance is computed as the difference between non-mineral revenue and expenditure (excluding } \\
\text { interest receipts and interest payments), divided by non-mineral GDP. }\end{array}$} \\
\hline
\end{tabular}




\section{INTERNATIONAL MONETARY FUND}

\section{BOTSWANA}

\section{STAFF REPORT FOR THE 2015 ARTICLE IV CONSULTATION}

March 1, 2016

\section{KEY ISSUES}

Context. Botswana's diamond endowment and its track record of good macroeconomic policy management and political stability contributed to high average economic growth and strong fiscal and balance of payments positions in recent years. Beyond these achievements, the authorities see a need to reduce unemployment, eliminate water and electricity shortages, and improve the efficiency of government operations. In addition, given the limits of the diamond and public sector-based growth model (diamond reserves could be exhausted by 2050 and inefficiencies in the public sector), a wave of reforms is called for to foster the development of the private sector, diversify the economy, and improve the skills of the labor force.

Recent Developments. Real GDP growth is estimated to have turned negative in 2015 owing to weaknesses in the global demand for diamonds and a deceleration of activity in the nonmining sector, driven mainly by spillovers from lower mining activity. Inflation has been low and is now near the lower bound of the Bank of Botswana objective range of 3-6 percent.

Outlook. The economy is expected to recover gradually over the next three years, driven by a gradual pick up in global diamond prices and fiscal stimulus. The main risks to the outlook are a slowdown in economic activity in major advanced and emerging markets and delays on restoring reliability and self-sufficiency in water and electricity and in implementing other structural reforms.

Fiscal and monetary policies. The 2016/17 budget presented to Parliament in February envisages high levels of public investment and a higher fiscal deficit. The stimulus is justified in the face of a negative output gap, strong fiscal buffers, and the need to close the infrastructure gap. However, its scale may be ambitious given past difficulties in implementing infrastructure projects. The Bank of Botswana's accommodative monetary policy stance is appropriate, although the space for further monetary easing will be constrained by the fiscal expansion. The financial sector is stable but requires continued monitoring.

Main recommendations. In the near-term, the priorities are to increase the efficiency of public investment, reform the water and energy sectors, and improve workers' skills and the business environment. In the medium-term, the growth strategy needs to be focused on a few areas and backed by bold reforms to mobilize domestic revenues, rationalize government spending and state-owned enterprises, implement a well-prioritized public investment program and consider adopting a sound fiscal rule, and improve education and labor market policies. 
Approved By Anne-Marie Gulde-Wolf (AFR) and Luis Cubeddu (SPR)
The discussions took place in Gaborone in the period December 7-22, 2015. The staff team comprised Mr. Gelbard (head), Ms. Marchettini, Mr. Torres, Mr. Issoufou (all AFR), and Ms. Moldovan (RES). The mission worked together with a concurrent mission by Mr. Aziz (AFRITAC South) on public financial management, who also participated in the policy meetings.

The staff met with the Governor of the Bank of Botswana Ms. Linah Mohohlo, the Minister of Finance and Development Planning Mr. Kenneth Matambo, other senior officials, and representatives of the donor community, civil society, and the financial sector.

\section{CONTENTS}

CONTEXT

RECENT DEVELOPMENTS

A. Policy Mix, Fiscal Risks, and Financial Stability $\underline{12}$

B. Enhancing the Framework for Economic and Financial Stability $\underline{14}$

C. Diversification and inclusive growth

OTHER ISSUES

STAFF APPRAISAL

\section{BOXES}

1. Developments in the Diamond Industry____ 11

2. Investment Scaling Up Scenario

\section{FIGURES}

1. Macroeconomic Developments

2. Monetary Policy and Exchange Rate

3. Macroeconomic Performance and Resource Intensity

\section{TABLES}

1. Key Issues From Previous Article IV Consultations

2. Selected Economic and Social Indicators, 2012-20

3a. Central Government Operations, 2012/13-2020/21

3b. Central Government Operations, 2012/13-2020/21 
3c. Central Government Operations, 2012/13-2020/21

4. Balance of Payments, 2012-2020

5. Monetary Survey, 2012-2020

6. Financial Soundness Indicators, 2012-2015:Q3

7. Risk Assessment Matrix (RAM)

\section{APPENDICES}

I. International Reserve Adequacy ___ $\underline{32}$

II. External Stability Assessment__

III. Debt Sustainability Analysis __ $4 \underline{40}$

IV. Fiscal Rules for Botswana____ 46

V. Scaling Up Public Investment: Simulations with the DIGNAR Model ___ $\underline{51}$

VI. Press Release___ $\underline{55}$ 


\section{CONTEXT}

Botswana has experienced strong economic growth since independence, owing to the country's stable political environment, prudent management of natural resources, and good governance record. In the period ahead, the main challenges are to ensure fiscal consolidation, diversify the economy, and foster inclusive and sustained growth.

\section{Botswana has enjoyed high growth and economic stability over the years, although} unemployment remains high. From 1966 to 2014, GDP per capita grew at an annual average rate of 5.9 percent, taking the country from low to middle-income status. Key to this success has been the prudent management of the country's diamond endowment, which contributed to strong fiscal and external positions including a large stock of foreign exchange reserves (the largest portion of which is saved inside the Pula Fund) ${ }^{1}$, and earned the country the best sovereign rating in Africa. ${ }^{2}$ In addition, monetary policy has kept inflation low, while a managed exchange rate policy helped reduce real exchange rate volatility. ${ }^{3}$ However, despite major progress in poverty reduction, unemployment remains high at nearly 20 percent.

\section{The country's performance also reflects good governance, political stability, and a leadership committed to strong institutions and development. Botswana has built one of the} strongest institutional setups in Africa, and the country is consistently ranked at or near the top in terms of quality of governance and rule of law in the continent. ${ }^{4}$ Political stability has prevailed since independence in 1966, with the political scene dominated by the Botswana Democratic Party. The party retained power in the 2014 general election, securing a second presidential mandate for President Khama, although its share of the vote dropped below 50 percent (to 46.7 percent) for the first time. The next general election will be held in October 2019.

3. Looking ahead, several challenges remain. The main short-term challenges are to manage the current economic downturn associated with the reduced global demand for diamonds and address major electricity and water shortages. In the medium to long-term, the main challenges are to remove constraints to private sector development in order to accelerate diversification and make

\footnotetext{
${ }^{1}$ The Pula Fund is a sovereign wealth fund established in 1994 with the goal of preserving part of the income from diamond exports for stabilization and investment purposes and for future generations. The Fund has two accounts: the excess reserves account (owned by the Bank of Botswana) and the Government Investment Account (owned by the government). In addition, the central bank has a separate pool of foreign reserves in a liquidity portfolio, normally equivalent to six months of non-diamond imports.

2 Botswana sovereign rating is A- according to S\&P and A2 according to Moody's.

${ }^{3}$ Since 2005, Botswana has maintained a crawling peg mechanism where the value of the Pula is determined against a basket of currencies representing major trading partners (the South African Rand and the SDR). The rate of crawl is set annually aiming to compensate for the projected inflation differential between Botswana and its trading partners.

${ }^{4}$ The country is thirty-first on the 2014 Transparency International Corruption Perceptions Index, the highest ranking in Africa. According to the 2015 Ibrahim Index of African Governance, Botswana ranks third in the continent, after Mauritius and Cape Verde. Still, there is room for further improvement, especially on business and labor regulations.
} 
growth more inclusive. In this connection, consultations will be taking place to finalize a new six-year National Development Plan (NDP11) by the end of 2016, the main goals being economic diversification and sustainable development.

\section{There has been broad agreement between the staff and the authorities on policies and reform priorities, with changes in the staff advice reflecting evolving circumstances.}

Surveillance recommendations have been closely integrated with IMF technical assistance, with substantial progress on fiscal consolidation, a medium-term expenditure framework, and financial sector regulation and supervision. Progress has been slow or less linear in broadening the tax base, rationalizing state-owned enterprises, and reducing the wage bill as a share of GDP, although the 2016/17 draft budget aims at containing the wage bill, subsidies, and transfers to state owned enterprises (SOEs) (Table 1). ${ }^{5}$ Changes in the staff advice reflect changes in macroeconomic circumstances. For instance, an expansionary fiscal stance is warranted in the near-term given the sharp slowdown in demand and higher fiscal and external buffers.

\section{RECENT DEVELOPMENTS}

The economy has entered a period of weakness connected to a decline in the global demand for diamonds which have also affected the country's fiscal and external positions, while successful monetary and financial policies have kept inflation in check and the financial sector stable.

\section{The economy has been slowing down, while inflation has been within the Bank of} Botswana's objective range of 3-6 percent. Following a healthy recovery after the 2009 downturn, economic growth slowed down in 2014 and is estimated to have come to a halt in 2015.

Both external and domestic factors contributed to the slowdown. Mining GDP was affected by a decline in the global demand for diamonds and copper, while non-mining GDP decelerated owing to spillovers from lower mining activity, a regional drought, electricity and water shortages, and less favorable domestic credit conditions. The decline in non-mining GDP growth was cushioned by an expansionary fiscal policy (see below). Inflation has also been in decline (the 12 month-rate of inflation was 2.7 percent in January 2016), reflecting a prudent monetary policy, lower fuel import prices, and a recent appreciation of the Pula against the South African Rand (Figure 1 and Table 2).

\section{After three years of surpluses, the government balance has turned into deficit.}

The fiscal deficit for FY 2015/16 (the fiscal year runs from April 1) is estimated to be in the order of 3 percent of GDP on account of lower mineral revenues, reduced receipts from the Southern African Customs Union (SACU), ${ }^{6}$ higher wages and transfers to state-owned enterprises, and higher capital

\footnotetext{
${ }^{5}$ Botswana has 19 SOEs in a number of commercial activities including telecommunications, energy, and transport. The Botswana Power Corporation and the Water Utilities Corporation, both under the Ministry of Minerals, Energy and Water Resources, are among the most important SOEs in the country.

${ }^{6}$ SACU receipts have been declining as share of GDP since 2012, owing to a deceleration in South Africa's GDP growth (which lowered import growth) and the appreciation of the pula against the rand. Payments will fall further in FY 2016/17, reflecting a further reduction in South Africa's growth and a repayment to the SACU pool for excess transfers in FY 2014/15 (transfers for the subsequent year are based on projections and are reconciled two years later).
} 
expenditure (Tables 3a-c). The latter reflects an "Economic Stimulus Program" that began to be implemented in the second half of 2015 to counteract the economic slowdown and includes higher capital expenditures targeting the tourism, transport, and agriculture sectors. ${ }^{7}$ As Botswana entered the downturn with sizable fiscal savings, the deficit is being primarily financed by government deposits.

7. The current account surplus has declined, but foreign reserves remain high. The current account surplus is estimated to have fallen from a peak of 16 percent of GDP in 2014 to about 9 percent in 2015 on account of (i) lower prices and volumes of diamonds and copper exports; and (ii) lower SACU revenues (Table 4). Despite a small decline in 2015, the stock of foreign exchange reserves remain comfortably high at US $\$ 7.5$ billion (65 percent of GDP), well above the upper bound of the optimal range estimated by the Adequacy of Reserves Assessment metric (Appendix I).

8. Minor adjustments were made to the exchange rate framework. To better reflect trading partners' trade weights and inflation differentials (particularly an increase in South Africa's projected inflation), the Bank of Botswana (BoB) increased slightly the target rate of crawl of the Pula from a downward crawl of 0.16 percent in 2014 to zero in 2015 and to 0.38 in 2016, and reduced the basket weight for South Africa from 55 to 50 percent in $2015 .^{8}$ The real effective exchange rate remained virtually unchanged in 2015, and the staff assessment of the real value of the Pula suggests that it is consistent with economic fundamentals (Appendix II).

\section{Monetary policy has been eased but transmission through the credit channel has been}

weak. In the context of declining inflation, the BoB reduced its policy rate from 7.5 in 2014 to 6 percent in 2015. These cuts have been consistent with cyclical developments as confirmed by a standard Taylor rule (Figure 2). ${ }^{9}$ Even though the prime lending rate fell in response to policy easing, credit growth declined as commercial banks adopted a cautious approach to lending in the context of slow growth in customer deposits and increasing competition to raise funds (Table 5). ${ }^{10}$ To further ease liquidity conditions, the Primary Reserve Requirement on Pula denominated deposits was reduced from 10 percent to 5 percent in 2015.

\footnotetext{
${ }^{7}$ The revised budget envisages an increase in capital expenditure of Pula 2.7 billion compared with the initial budget.

${ }^{8}$ The Renminbi will enter the SDR basket in October 2016. The basket weights and crawling rate will remain unchanged for the rest of 2016 and may be revised again in 2017 depending on trade patterns and projected inflation differentials.

${ }^{9}$ A standard Taylor rule: $i=p+1 / 2 \cdot\left(y-y^{*}\right)+1 / 2 \cdot\left(p-p^{*}\right)+r^{*}$, where $i$ is the nominal policy rate, $p$ represents the rate of inflation over the previous four quarters, $\left(y-y^{*}\right)$ represents the percent deviation of real non-mining GDP from trend (non-mining output gap), $\left(p-p^{*}\right)$ is the percentage deviation from the inflation target, and $r^{*}$ is the equilibrium real interest rate was used. Non-mining potential output $y^{\star}$ and the equilibrium real interest rate $r^{\star}$ were computed by applying a backward looking HP filter. Given the BoB inflation objective range of 3-6 percent, the Taylor rule implied policy rate range is 5.75-6.00 percent in the third quarter of 2015.

${ }^{10}$ In 2014 and during the first half of 2015, excess liquidity in the banking system fell as lending increased but deposit growth was sluggish, leading to a marked increase in the cost of funding as banks competed for deposits.
} 
Figure 1. Botswana: Macroeconomic Developments

Mining sector activity contracted in recent quarters, while non-mining GDP growth remained positive but slowed.

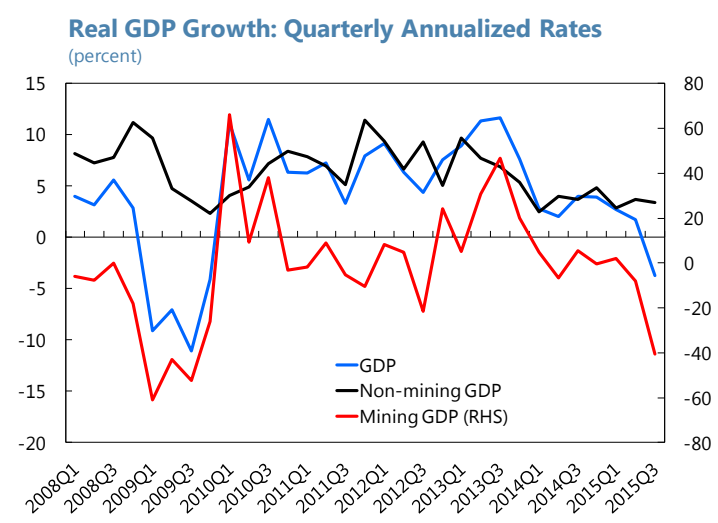

Inflation declined significantly over the past months, reaching the lower bound of the $B O B$ objective range.

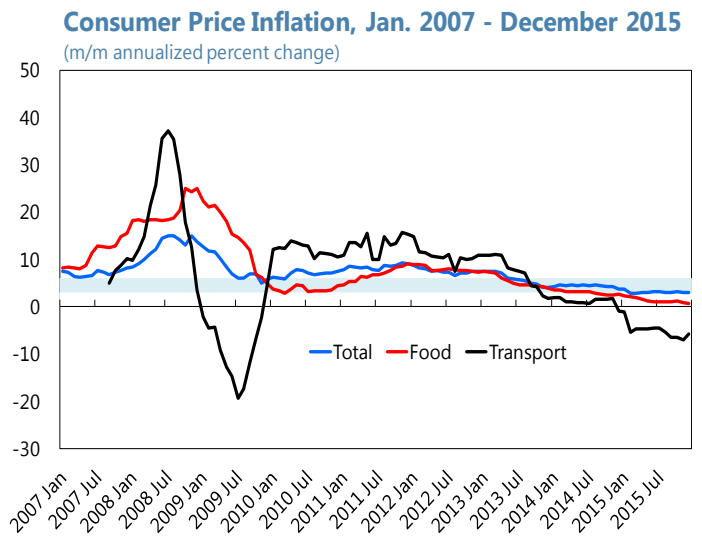

After recovering from the 2009 downturn, the current account weakened in 2015, due to reduced diamond trade and SACU transfers

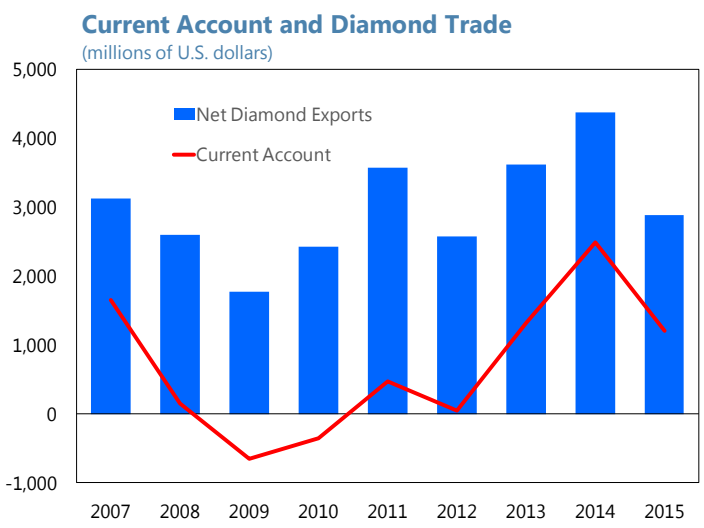

A reduction in the global demand for diamonds has lowered export prices and Botswana's diamond production.

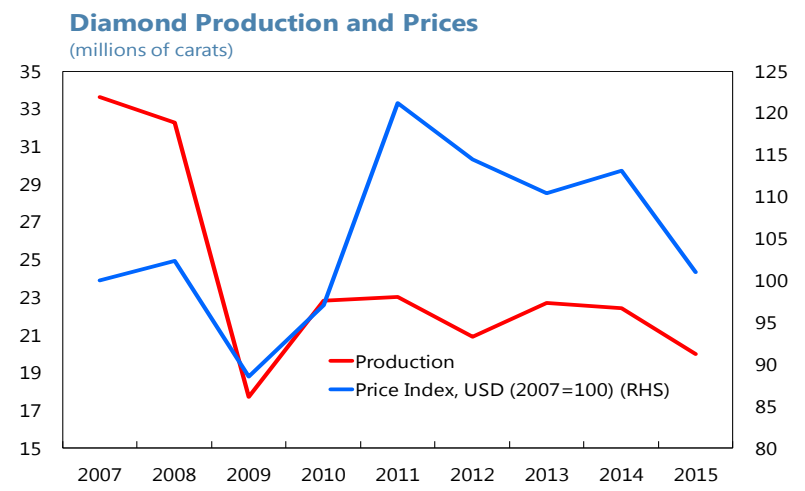

After recent surpluses, the fiscal position has turned into a deficit owing to lower mineral and SACU revenue and higher spending.

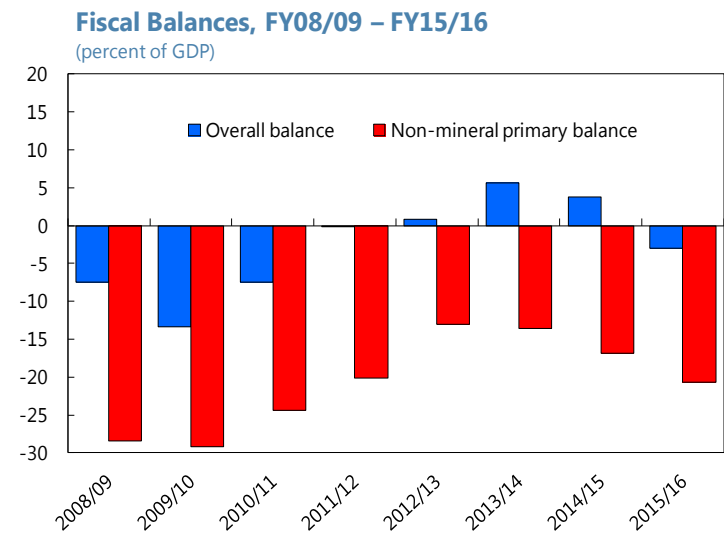

While foreign reserves remain comfortably high.

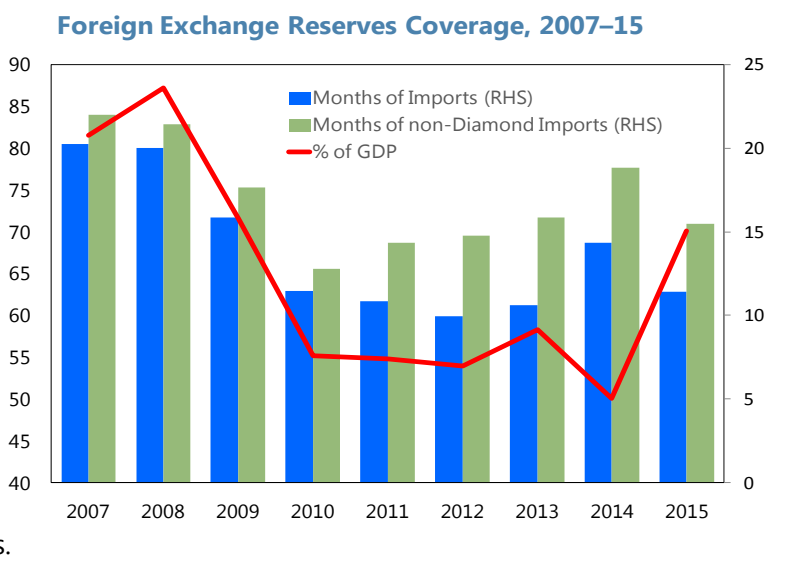


Figure 2. Botswana: Monetary Policy and Exchange Rate

Interest rate cuts have been consistent with cyclical developments as confirmed by a standard Taylor rule...

Taylor Rule-Derived Interest Rates and Actual Rates

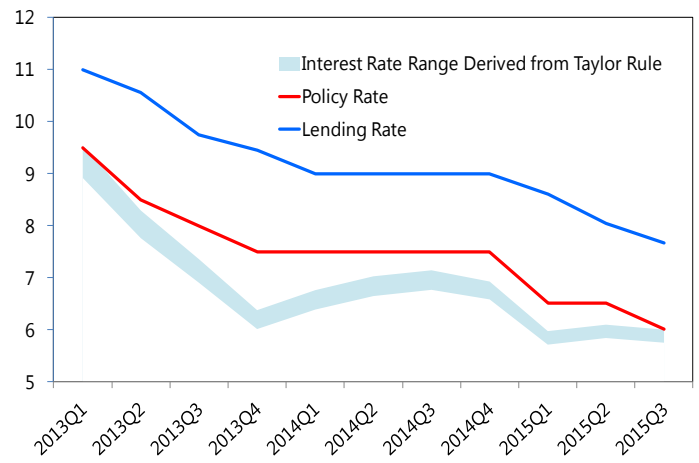

To further ease liquidity conditions, the BoB decreased the reserve requirement on pula-denominated deposits in early 2015.

Broad Money Liabilities Growth Rate, Jan 2013-Nov 2015 $(Y / Y$, percent)

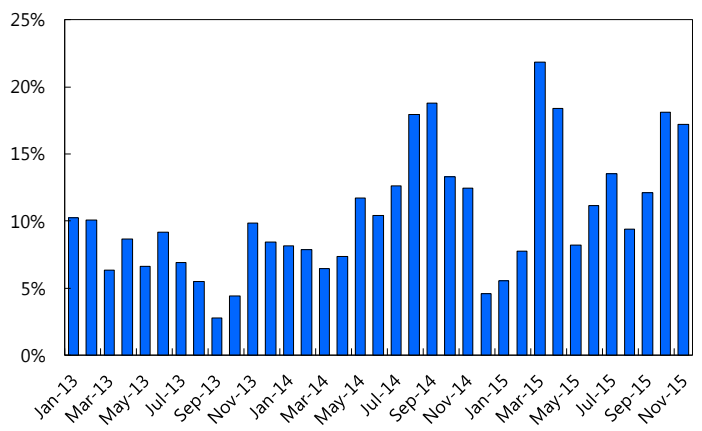

The rate of crawl was set to zero in early 2015 given the erosion of inflation differentials with major trading partners

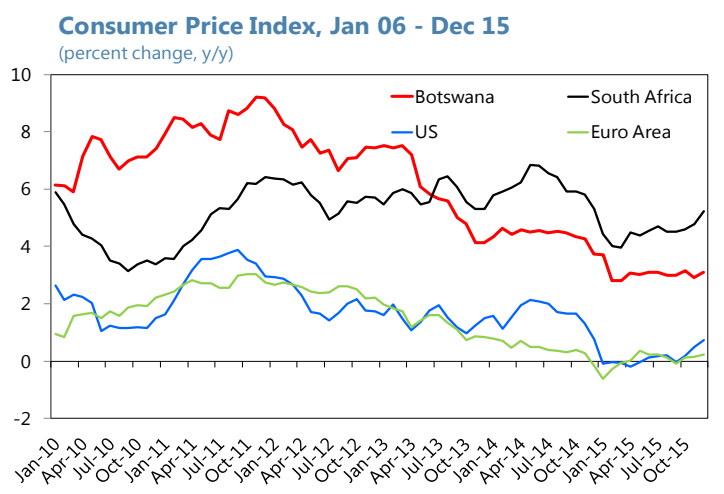

...In addition, the BOB Policy Rate remains above the SARB Repo Rate in real terms.

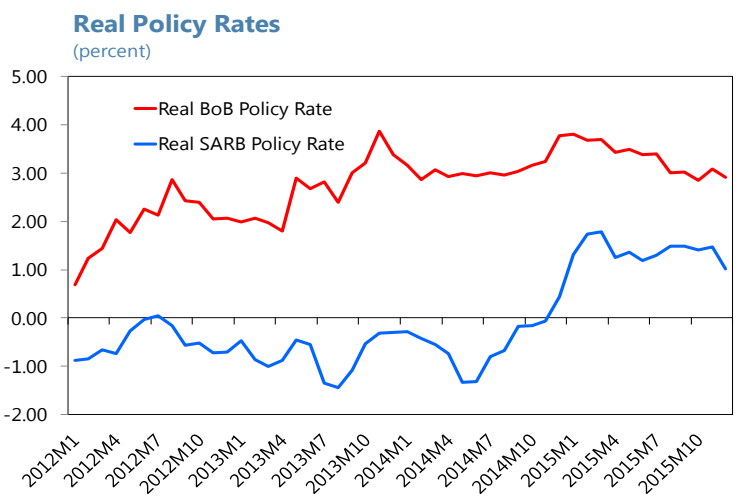

Despite an accommodative monetary stance, credit growth has continued to decline owing to anemic growth in bank deposits, but credit to households is recovering.

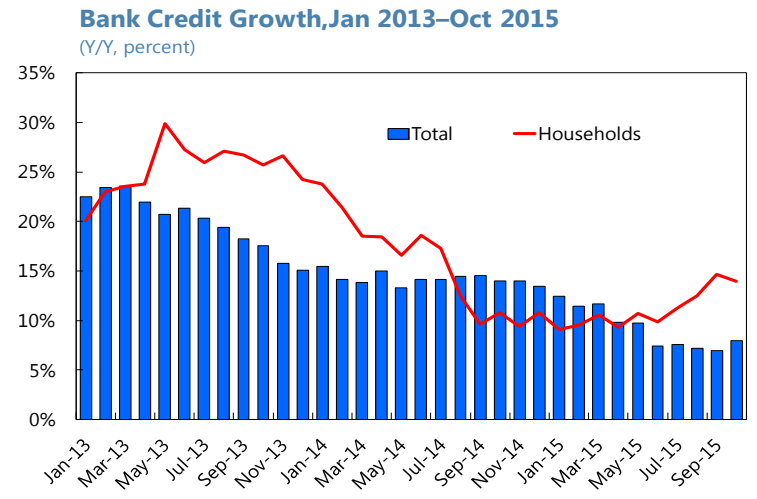

The nominal and real effective exchange rates have remained broadly stable over the past few years

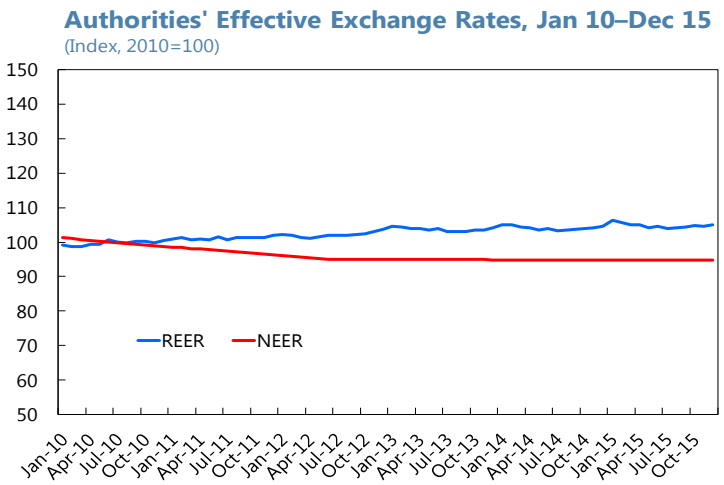

Sources: Botswana authorities, IMF staff estimates. 
10. The financial system is stable, but some vulnerabilities remain. There are 11 banks in the system alongside several non-bank financial institutions providing a variety of modern services. Banks are well capitalized, with an average capital adequacy ratio of 21 percent and a low share of non-performing loans (4.5 percent of total gross loans) (Table 6). Nevertheless, asset quality deteriorated during the past year, profitability declined slightly, and funding conditions became more challenging, especially for smaller institutions. ${ }^{11}$ While the system remains sound, a major economic contraction could raise stability risks given lenders' relatively large exposure to households (59 percent of total bank loans), which is mainly in the form of unsecured lending (about 65 percent of total credit to households).

\section{OUTLOOK AND RISKS}

Armed with ample savings and foreign reserves, the authorities are well-positioned to weather the current slowdown. The economy is expected to recover gradually, driven by a pick up in the global demand for diamonds and fiscal stimulus, while custom receipts are expected to remain subdued. The main risks to the outlook are sluggish external demand for minerals and slow or insufficient reforms.

11. The baseline scenario assumes a gradual recovery in the next three years and modest growth in the longer term. The projection is based on the assumption of a measured recovery in global diamond and copper prices (Box 1). It also reflects the impact of higher government spending and investments in the energy and water infrastructure, together with gradual reforms to improve the business environment, which could bring real GDP growth towards 5 percent by 2019 . Subsequently, the baseline projects annual average real GDP growth of around 4 percent based on the withdrawal of the fiscal stimulus and continued prudent macroeconomic policies and economic reforms. Inflation is projected to remain within the BoB's objective range.

\section{The fiscal and external positions are expected to deteriorate further in $\mathbf{2 0 1 6}$ and} improve thereafter. The 2016/17 budget entails a fiscal deficit of about 4 percent of GDP, the result of lower mining and SACU revenues and the continued implementation of the government's stimulus program. Fiscal consolidation is expected over the medium-term, based on a gradual recovery of the mining sector and expenditure rationalization (Tables $3 b-c)$. On the latter, the authorities envisage containing the growth of wages and salaries and lowering transfers to stateowned enterprises, especially electricity and water. Regarding the external position, the current account surplus is projected to narrow further from 9 percent of GDP in 2015 to about 2 percent in 2016 and reverse trend thereafter, alongside a projected recovery in diamond prices and volumes (supported by a gradual pickup in global demand).

\footnotetext{
${ }^{11}$ While the shortage of liquidity has been alleviated by the reduction in the Primary Reserve Requirement and a portfolio reallocation of the Botswana Public Officers Pension Fund in the first half of 2015, the cost of attracting customer deposits has been on the rise, particularly for smaller institutions, and banks' funding structure remains skewed towards volatile wholesale deposits.
} 


\section{An alternative scenario entailing a stronger reform effort and prioritized public} investment has a better chance to address Botswana's challenges. Staff prepared an alternative scenario that suggests that, with accelerated reforms, a gradual and well-prioritized public investment program, and improved efficiency in the public sector, the country will be in a better position to achieve economic diversification, higher growth, and a transition to high-income status (see below).

14. There are important risks to the outlook. In the near term, the main downside risks are: (i) sluggish growth in key advanced and emerging economies, that could lead to continued weakness in the demand for diamonds (and copper); (ii) unresolved economic problems in South Africa and continued depreciation of the Rand, which could lower SACU receipts and have a negative impact on regional investors' sentiment ${ }^{12}$; and (iii) delays in plans to restore reliability and self-sufficiency in the water and electricity sectors, which would have adverse impact on costs, the fiscal balance, and the business environment; as well as delays on other structural reforms (e.g. deregulation and removal of red tape). On the upside, a faster than expected recovery in the global demand for minerals could enable a faster recovery. In the longer term, the main risks relate to insufficient or ineffective actions to improve the efficiency of public investment and foster fiscal consolidation, economic diversification, and inclusive private sector-led growth (Table 7).

\footnotetext{
${ }^{12}$ There is also the latent risk of a change in the SACU revenue-sharing formula that could result in even lower revenue flows and a more serious fiscal pressure. A reform of the SACU revenue-sharing formula has been on the agenda for several years but no decision has been made in light of concerns by Botswana, Lesotho, Namibia, and Swaziland. The baseline projections do not assume a change in the formula.
} 


\section{Box 1. Botswana: Developments in the Diamond Industry ${ }^{1}$}

Diamond production is concentrated in two major country groups: a northern one, which includes Russia and Canada, and a Southern one that includes mainly Southern African states. There is another, less significant, group that produces diamonds of lower value and includes the Democratic Republic of Congo. The top three producing countries are Botswana, Russia, and Canada, accounting respectively for 25.5, 24.1, and 13.7 percent of world output, respectively. The rough diamond market is dominated by two companies: De Beers and ALROSA, each accounting for 34 and 25 percent of the world market. On the demand side, the U.S. represents about 40 percent of the global market for polished diamonds, followed by China/Honk Kong/Macau (15 percent), India (8 percent), the Gulf Region (8 percent), and Japan (6 percent).

Diamond Production by value - Average 2013-2014

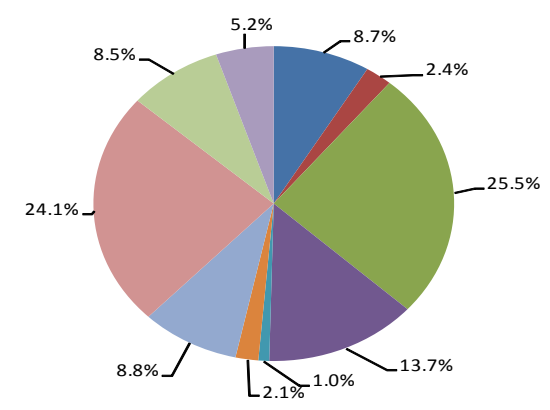

Angola

- Australia

- Botswana

- Canada

DRC

Lesotho

Namibia

Russia

- South Africa

Others

Source: Kimberley Process Certification Scheme

The global demand for polished diamonds started to fall in the second half of 2014 prompted by a slowdown in China's economy and signaling a reversal from a period of high growth (which had led to overly optimistic market expectations). This, together with a slowdown in other markets, led to an accumulation of inventories of polished diamonds and lower demand for rough diamonds. Between mid-2014 and September 2015, prices for polished and rough diamonds decreased by 12 and 23 percent respectively. Consequently, major producers started cutting production beginning in the second half of 2015. In Botswana, De Beers reduced production by about 20 percent in 2015 and announced further cuts for 2016. Debswana - the 50/50 joint venture between De Beers and the government of Botswana-put its Damtshaa mine on care and maintenance status and plans to scale down production at the Orapa 1 mine for the period 2016-2018.

Notwithstanding these negative developments, market observers coincide that with a careful management of supply, diamond prices may rebound as excess inventories clear, although uncertainties remain as to whether the recent decline in demand is transitory or structural (as diamonds are not a exchange traded commodity,

information on prices and volumes is limited, which constrains the scope for analytical work on developments and prospects). For instance, Bain and Company (2015), expects demand to return to a long-term growth trajectory of 3-4 percent per year, relying on strong fundamentals in the US and continued growth of the middle classes in India and China. At the same time, the U.S. market is largely saturated, and while demographic changes in the faster growing countries would in principle favor increased demand for diamonds, consumer preferences in younger generations across the globe may be shifting. On the supply side, output is expected to decline by 1-2 percent per year through 2030, based on an analysis of existing and prospective volumes inferred from publicly announced plans by producers. Other factors that could affect market developments are, on the one hand, the recycling of diamonds and the emergence of synthetic stones and, on the other hand, the fact that new diamond deposits could be further underground and much more costly to extract.

Lastly, the industry faces other challenges in its value chain. Cutting and polishing firms may not be robust enough to cushion against short-term fluctuations in the retail market, given their constrained bargaining power over producers and retailers and limited access to financing. In fact, lower margins are driving weaker firms out of business, most of them in Africa (in 2015, the combined market share of cutting and polishing firms in China and India rose to 85 percent while the share of African companies declined, reflecting insufficient competitiveness of the latter).

${ }^{1}$ Sources: Bain and Company The Global Diamond Industry 2015, December 2015; McKinsey\&Company Perspective on the Diamond Industry, September 2014; public websites of Kimberley Process Certification Scheme and De Beers Group. 


\section{POLICY DISCUSSIONS}

15.

The discussions focused on the near term policy mix to counter the economic downturn, contain fiscal risks, and preserve financial stability as well as on selected medium-term issues, namely measures to improve the efficiency of public investment, strengthen the frameworks for managing mineral revenues and the financial sector, and foster job creation and private sectorled growth.

\section{A. Policy Mix, Fiscal Risks, and Financial Stability}

As the fiscal stimulus is rolled out, additional monetary easing may not be required, but the authorities need to be cautious with public investment projects and consider reforms to mobilize revenue in order to limit fiscal risks. Financial sector risks call for continued close monitoring of the sector.

\section{Given a negative output gap, some near-term easing of macroeconomic policies is} appropriate. Staff estimates a negative 1.4 percent output gap in non-mining GDP (as of the third quarter of 2015), supporting the case for expansionary policies. As inflation has approached the lower band of the BoB's objective range, and in light of a relatively weak monetary transmission mechanism, the authorities have been appropriately shifting the policy mix in favor of fiscal stimulus. Furthermore, the space for further monetary easing in the period ahead may be constrained by rising global interest rates.

\section{The $\mathbf{2 0 1 6 / 1 7}$ budget envisages a larger overall deficit with a strong focus on public investment and restraint on recurrent expenditures. The budget submitted to Parliament in} February 2016 roughly maintains the level of spending in nominal terms compared to the previous year's projected outturn, but proposes somewhat higher capital expenditures and lower wages and transfers to SOEs (Table 4a). ${ }^{13}$ As mineral and non-mineral revenues remain subdued, the fiscal deficit is projected to reach about 4 percent of GDP and be financed by government deposits and domestic . ${ }^{14}$ Going forward, the authorities indicated that they would continue to limit public spending by containing the wage bill, subsidies, and transfers to SOEs. ${ }^{15}$

\section{The drawdown of government deposits from the central bank could improve liquidity} conditions. The change in fiscal policy is expected to enhance monetary policy transmission through the lending channel (i.e. by releasing commercial banks' liquidity constraints through increased deposits); in this way supporting domestic demand. In this regard, the BoB agreed on the

\footnotetext{
${ }^{13}$ Despite the higher overall deficit, the non-mining primary deficit is projected to improve slightly by 1.6 percent of GDP (relative to the current fiscal year).

${ }^{14}$ The focus on domestic debt reflects the intention to further develop the domestic debt market and the fact that the level of external debt is nearing the statutory limit of 20 percent of GDP.

${ }^{15}$ The authorities expect to contain the wage bill through limits and reductions in non-salary components such as travel and overtime. Meanwhile, transfers to SOEs are projected to decrease as the regional drought comes to an end and water and electricity constraints are progressively eased (through higher domestic production).
} 
need to continue using existing liquidity management tools (i.e. auctions of BoB certificates and repo transactions) and lending facilities to ensure that interest rates and liquidity conditions are consistent with sustainable credit growth and the BoB inflation objective. Should inflationary pressures emerge, the BoB stands ready to tighten monetary policy.

\section{Concerns about investment efficiency call for caution on public investment plans.}

The staff pointed out that, in light of difficulties and delays experienced in previous years with the execution of investment projects, a more cautious approach may be warranted-including in project selection - to increase the odds that projects can be efficiently executed and prevent the waste of public resources. The authorities indicated that they were making every effort to address this concern and ensure that the additional investment would be effectively implemented. They were also receptive to staff proposals to move forward with complementary reforms that could, over time, build implementation capacity and ensure higher investment efficiency (see Section C).

\section{Constrained mining and SACU revenues highlight the importance of domestic revenue}

mobilization. The authorities noted their commitment to return to a fiscal surplus within the next three years. The staff concurred on the importance of avoiding protracted fiscal deficits that could compromise fiscal and foreign exchange reserves and the country's track record of fiscal discipline. The staff also noted that, in light of the recent decline in mining and SACU revenues and uncertainties about their level in coming years, it would be important to consider domestic revenue reforms to improve VAT collections, review exemptions, and reform property taxation. ${ }^{16}$ The authorities indicated that, while they were not planning any major reform in 2016/17 (also as a way to avoid interfering with the stimulus program); they intended to continue with efforts to mobilize revenue and requested IMF technical support to conduct a diagnostic of tax administration.

\section{A number of actions were discussed to mitigate financial sector risks in a slowing economy, namely:}

$>$ The authorities agreed on the staff proposal to perform annual on-site supervisory reviews of each institution deemed systemic (regardless of its CAMEL rating) in addition to the already established supervisory framework for banks with a higher risk profile.

$>$ Given the large exposure of banks and non-bank lenders to the household sector, the BoB will consider conducting a stress test exercise aimed at assessing the impact of different shocks on households' debt-servicing capacity. ${ }^{17}$

\footnotetext{
${ }^{16}$ VAT collection averaged 5 percent of non-mining GDP over the past three years. A preliminary estimate of the additional revenue potential from enhanced administration point to possible gains of 2 percentage points of nonmining GDP; this does not include gains from rationalizing exemptions. In addition, there is scope to increase the property tax rate (which is low by international standards) and the valuation and coverage of residential and commercial properties (the additional revenue potential has been estimated at 0.6 percent of GDP).

${ }^{17}$ Should NPLs increase, the BoB is expected to manage the risk by encouraging higher provisions and continue to ensure compliance with provisioning rules.
} 
$>$ The staff supported the efforts of the Non-Bank Financial Institutions Regulatory Authority (NBFIRA) to implement a tiered prudential framework for large non-bank lenders by September 2016 in line with IMF technical assistance recommendations (there are close links between large non-bank lenders and the banking sector, implying contagion risks). ${ }^{18}$

$>$ To improve access to credit and lenders' capacity to screen borrowers, the authorities agreed on the importance of expediting the reform of credit bureaus to reduce fragmentation of credit information and broaden the scope of the creditor database to both positive and negative credit data. The reform also envisages allowing lenders to enforce securities out of court through a collateral agreement in case of defaults and introducing a collateral registry for immovable and movable assets.

$>$ Lastly, to deal with limited monetary policy pass-through, the staff noted that the authorities could consider the introduction of new liquidity and/or lending facilities at the central bank, such as open market operations involving a lengthening of the average maturity period, but this may not be needed in the short run as fiscal policy takes center stage. Over time, however, changes in banks' asset/liability management and some consolidation in the sector (the market is rather small but there are 11 commercial banks operating) may be appropriate.

\section{B. Enhancing the Framework for Economic and Financial Stability}

Building on a good track record of fiscal soundness and macroeconomic stability, there is scope to strengthen the framework for managing mineral revenues and safeguard financial stability.

\section{Over the past decade, Botswana experienced higher, albeit more volatile, economic} growth than other SACU members. Prudent macroeconomic policies, a strong institutional setup, and the country's dependency on mining, especially diamonds, explain this outcome. While the share of mining in GDP has declined from 28 percent of real GDP in 2007 to 17 percent in 2014, it nonetheless remains high (Figure 3 ) and the exposure of other sectors to diamond market developments has actually increased as a result of the Diamond Hub Program aimed at developing the downstream segment. ${ }^{19}$ Also, the fiscal and external positions are highly dependent on minerals, which account for 39 percent of government revenues and nearly 90 percent of goods' exports.

\footnotetext{
18 Larger non-bank lenders are treated as 'micro lenders' under the NBFIRA Act but have business models that are more like small retail banks. However, total assets of the micro-lending sector are limited when compared to the banking sector (about 4 percent of banks' total assets).

19 The downstream sector has been exposed to higher pressures than the upstream segment as, in addition to reduced prices for polished diamonds; access to lending for firms operating in the segment has declined with the closure of Antwerp Diamond Bank (the second biggest diamond bank in the world) at end-2014, adding funding constraints to reduced profitability. Since the beginning of 2015, a number of polishing and cutting firms in Botswana have closed, shedding about 1,000 jobs (out of a total of about 3,700 ).
} 
23. To date, the authorities have successfully implemented countercyclical policies, built strong buffers, and avoided debt accumulation. Foreign reserves and fiscal cushions have been built during booms and judiciously used during busts to smooth aggregate demand and economic activity. Combined with formal debt limits, this sound management has resulted in low debt levels and a strong net external credit position. As such, Botswana exhibits no debt vulnerabilities and remains a low debt scrutiny country (Appendix III). ${ }^{20}$

\section{Going forward, there is room to strengthen the principles for managing mining} receipts. Since 2006, debt ceilings on domestic and foreign debt, equivalent to 20 percent of GDP each, have been consistently observed. More recently, the authorities adopted two guiding principles in their National Development Plans, namely a 40 percent of GDP government spending cap introduced in 2006 and a target for reducing spending to 30 percent of GDP by the end of 2015/16. The 40 percent limit was only breached during the 2008 financial crisis, while the 30 percent target is not expected to be observed. In addition, a cap on government spending can give rise to unintended procyclicality; for instance, when the price of diamonds increases, GDP also increases, thus enabling for a corresponding increase in spending (Appendix IV). In the context of the forthcoming NDP11, the authorities are considering reviewing these principles. This is timely, given the experience so far and the importance of prudent fiscal management by future governments.

\section{Replacing the expenditure ceilings with a new fiscal rule and clearer links with the Pula} Fund and the budget process could help avoid pro-cyclical spending and ensure fiscal sustainability. The authorities may consider replacing the above principles (while retaining the legal debt ceilings) with a new (possibly legislated) fiscal rule. In this regard, one option could be a rule that ensures convergence of the non-mining primary balance (measured as non-mining revenue minus non-interest spending) as a share of GDP to a given level at the end of each NDP cycle. Regardless, any decision on a new fiscal rule will need to be carefully evaluated and accompanied by a framework that strengthens and clarifies the link between the budget process, Pula Fund deposit and withdrawal rules, and a public investment program.

\section{Regarding the financial sector, a formal macro-prudential framework and Basel II implementation could better protect the sector and the economy against future risks.}

The authorities have begun developing inter-agency cooperation on financial stability issues. Going forward, they agreed on the importance of strengthening their capacity to mitigate systemic risks, including through a formal institutional framework that assigns the macro-prudential mandate and the legal powers to exercise that mandate to an existing or new agency. The staff team also supported the BoB's efforts to implement the Basel II simplified standardized approach by 2017, including Pillar 2 requirements.

\footnotetext{
${ }^{20}$ Botswana's public and publicly guaranteed debt has been under 25 percent of GDP and declining and is projected to remain low over the medium-term, with sustainable debt dynamics under the baseline and standard stress tests.
} 
Figure 3. Botswana: Macroeconomic Performance and Resource Intensity

Botswana's economic performance has been stronger than other SACU members...

\section{Average Annual Growth Rates in Selected Middle Income Countries (MICs), 2006-2015 \\ Country \\ Average Growth Rate}

\begin{tabular}{l|l|}
\hline Botswana & $\mathbf{4 . 7 0}$ \\
\hline Namibia & 4.33 \\
\hline South Africa & 2.61 \\
\hline Swaziland & 2.73 \\
\hline Lesotho & 4.52 \\
\hline SACU & 3.78 \\
\hline Average of all middle & 4.02 \\
\hline income countries & \\
\hline
\end{tabular}

Reflecting higher exposure to minerals...

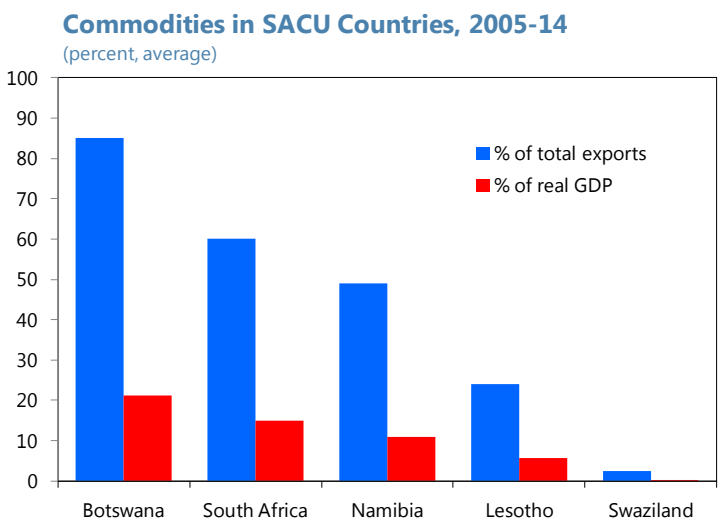

...Making the external current account susceptible to changes in the global demand for diamonds.

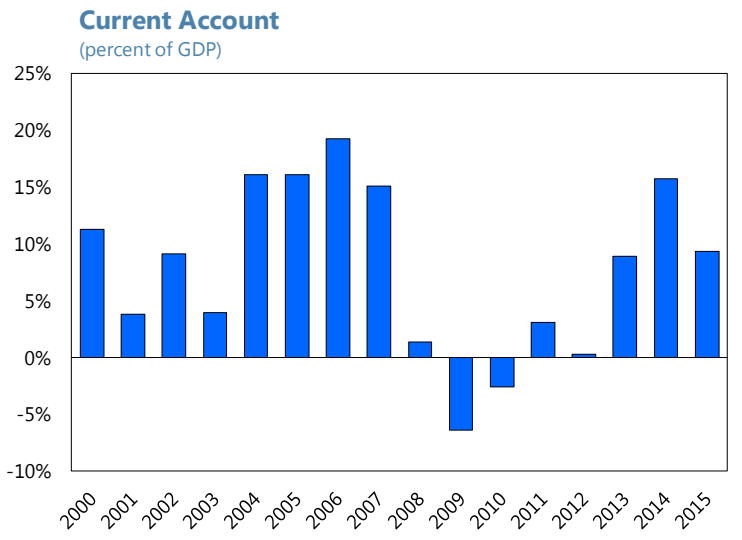

...but also more volatile.

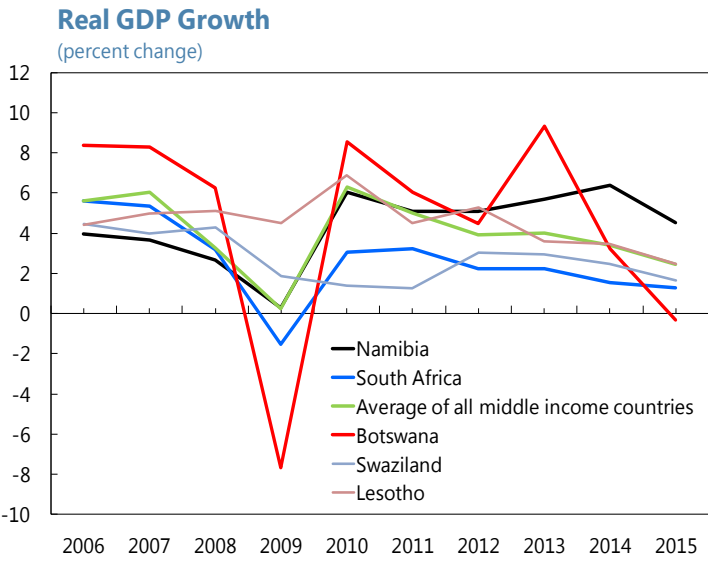

...and especially a heavy concentration of exports in diamonds

Mineral Export Composition, 2005-14

(percent of total, average)

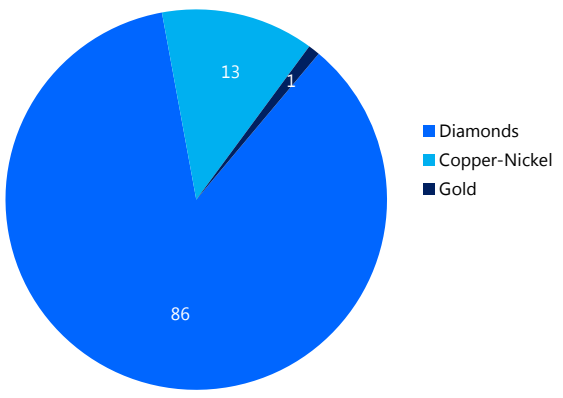

To counteract the impact of commodity volatility, the authorities have followed a countercyclical fiscal policy

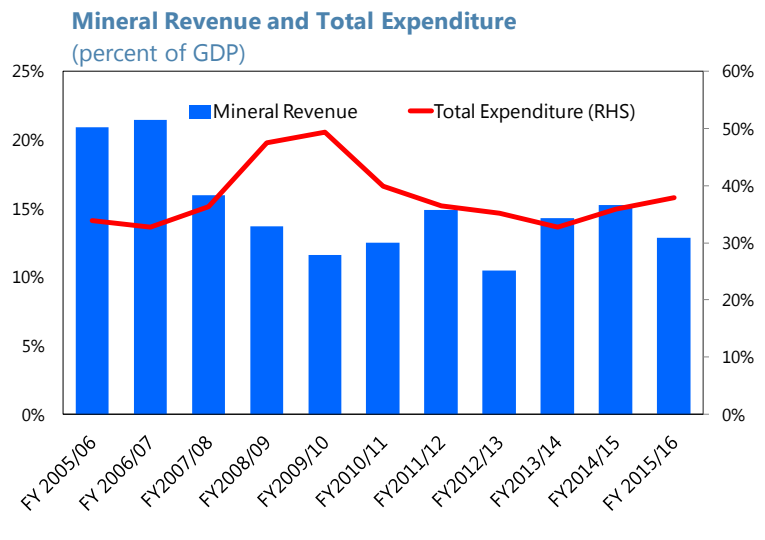

Sources: Botswana authorities, IMF World Economic Outlook, IMF staff estimates. 


\section{Diversification and Inclusive Growth}

Progress with economic diversification has so far been limited and high levels of unemployment persist, with most employment creation coming from an oversized public sector. Looking ahead, wellprioritized investments in education, energy, water, and other infrastructure will be critical, supported by reforms to improve the business environment and the efficiency of the public sector.

\section{While poverty has been rapidly reduced in recent years, unemployment remains high} and the economy remains largely undiversified. Significant progress has been achieved in poverty reduction (which declined from 31 percent in the early 2000s to 19 percent in 2009/10) ${ }^{21}$; but unemployment remains high at about 20 percent of the labor force. This mainly reflects a diamond and public sector driven growth model with insufficient private sector job creation. Outside of mining, the services sector has grown over the past decade (particularly financial services) but the development of other sectors has been limited, while the promotion of diamond beneficiation, aimed at fostering value chains, has been challenged by global demand volatility and competition from other countries such as India.

28. The recent electricity and water crises have limited private sector growth. Botswana has been facing an electricity crisis owing to problems with the commissioning of a major power plant (Morupule B) and other inefficiencies in service provision. ${ }^{22}$ As a result, in 2015 the country had to import 39 percent of its electricity needs. In addition, following the end of a long-term purchase agreement with a major provider, it had to import electricity at premium tariffs and without a guaranteed supply. This contributed to shortfalls, sizable fiscal transfers to the energy company, and rising tariffs. Regarding water, a recent drought has led to shortages that are compounded by low and unreliable rainfall and high levels of evaporation. Moreover, Botswana's dispersed population and a spatial mismatch between water resources and population centers raise the costs of delivering water.

29. A number of constraints hamper the development of the private sector. In the 2016 Doing Business report, the World Bank ranks Botswana 72 out of 189 countries, the main shortcomings being on health, education, labor skills, water and electricity supply, and public infrastructure. Similarly, Botswana ranks 71st out of 140 countries in the 2015/16 Global Competitiveness Report (World Economic Forum), with the main challenges relating to work ethics ${ }^{23}$ and education in the labor force, inefficient government, and restrictive labor regulations.

\footnotetext{
${ }^{21}$ Data based on the national poverty line as defined in the National Household Expenditures Surveys (Statistics Botswana (2011) "Preliminary Results of the Botswana Core Indicators Survey").

${ }^{22}$ The crisis is primarily linked to insufficient generation rather than distribution losses (see World Bank, Systematic Country Diagnostic, March 2015).

${ }^{23}$ Work ethic refers to reliability, discipline, responsibility, accountability, and time consciousness amongst workers.
} 
30. The authorities expressed their intention to accelerate steps to resolve the water and electricity crises. On the electricity sector, three units of the Morupule A power station and four units of the Morupule B power station are being refurbished and are expected to enter into production beginning in the last quarter of 2016. In addition, the authorities plan to build two additional coal powered units at Morupule B (with the first expected to begin production by 2018). The authorities expect that, with the existing and new units at full capacity, the country's total demand of about 600 megawatts would be more than fully covered by 2019 . The staff also encouraged the authorities to move ambitiously with plans to develop capacity based on solar energy in cooperation with the World Bank and actively involve the private sector in the process. Regarding the water sector, the authorities have begun the construction of a new North-South water pipeline. Lastly, the staff welcomed the authorities' intentions to introduce water and electricity regulators to oversee tariffs, costs, and quality of service as well as other aspects of the companies and the Ministry involved in the two sectors.

\section{The authorities agreed on the need to increase efficiency and the quality of public}

spending. The staff welcomed the authorities' plans to proceed with expenditure rationalization of the wage bill and transfers to SOEs in the medium-term. The authorities agreed that it would be useful to conduct an expenditure review of the seven largest spending Ministries ${ }^{24}$ to identify potential savings and improve spending efficiency, including service delivery. Regarding public investment, the authorities indicated that they would consider the following staff proposals:

$>$ Undertake a Public Investment Management Assessment to identify investment capacity constraints in the investment planning, allocating and implementing processes. ${ }^{25}$ The goal would be to help identify a feasible rate of scaling up public investment in line with capacity and a plan to address capacity constraints and institutional bottlenecks; and

$>$ Develop an annual public investment plan as part of NDP11 and in the context of the mediumterm fiscal framework, containing a prioritization of projects based on cost-benefit analysis and reflecting recurrent costs (operation and maintenance) in terms of financial resources and personnel.

\section{Further steps are also needed to improve the efficiency of public enterprises, including} through private ownership. A positive development has been the launch in December 2015 of the Initial Public Offering of Botswana Telecommunications Ltd, which marks the first important public offering of an SOE in Botswana. The staff welcomed this step and the authorities' goal to improve the efficiency of SOEs and involve the private sector in their ownership structure, and encouraged them to step up efforts to improve the profitability of these companies (especially in the energy and

\footnotetext{
24 These ministries account for about two-thirds of total government spending.

${ }^{25}$ PIMA is a comprehensive assessment of a country's public investment systems. It would cover the full investment cycle (planning, allocating, implementing, and monitoring), identify institutional strengths and weaknesses, and provide practical recommendations to increase the efficiency of investments.
} 
water sector), including through a restructuring of their operations and the introduction of private management teams as needed.

\section{Actions are also needed to improve the business environment and support}

employment creation. The authorities, in cooperation with the World Bank, have developed a timebound action plan that will-inter alia-streamline registration of new businesses, reduce red tape on construction permits, and facilitate access to credit. To reduce skills mismatches and improve the quality of the labor force, the authorities are also working to redesign programs (with private sector's participation) and provide scholarships for vocational training as well as incentives for firms to strengthen apprenticeship programs. The staff noted that, in addition to these steps, it would be important to reduce red tape and restrictions on work permits for skilled foreign workers, as this would raise productivity, facilitate the expansion of the private sector, and promote transfer of skills and know-how. The authorities, however, consider that such restrictions are not overly onerous and are necessary to protect local workers.

\section{An alternative scenario with faster and bolder reforms and investment scaling up could help develop the private sector, diversify the economy, and raise growth prospects.}

The staff prepared an alternative scenario that simulates a gradual scaling-up of public investment (about 2-3 percentage points of GDP above the baseline) over the 5-10 years together with reforms that improve the business environment and the efficiency of the public sector and of investment (Box 2 and Appendix $\mathrm{V}$ ). ${ }^{26}$ Under such scenario, it is projected that the long-run rate of real GDP could increase by about 1.2 percentage points per year on average (from 4 percent in the baseline to 5.2 percent).

\section{Lastly, the authorities are proceeding with plans to develop special economic zones.}

They intend to develop up to 8 economic zones centered on activities with perceived comparative advantage (e.g. mineral downstream activities, beef, leather, financial services, agricultural processing). The basic legislation has been enacted, but other specifics such as fiscal regimes and regulations are pending. The staff, pointing to disappointing results of many economic zones around the world, urged the authorities to avoid generous tax incentives and large investments with uncertain payoffs and proceed gradually with the zones. The authorities agreed in principle, but signaled that the zones could provide for a faster route to a deregulated business environment and, if successful, serve as a platform for their extension into the domestic economy.

\section{OTHER ISSUES}

\section{Botswana's macroeconomic statistics have continuously improved in recent years.}

Substantial progress in improving data quality, coverage, and frequency led Botswana to be the first

\footnotetext{
${ }^{26}$ The authorities would like to foster private participation in infrastructure financing through Public-Private Partnerships (PPPs) based on a policy framework set in 2009, but further regulations to refine the modalities of PPP projects are needed.
} 
country to subscribe to the Fund Enhanced General Data Dissemination System (e-GDDS) in January 2016. While the quality of macroeconomic data remains adequate for surveillance, enhancements in the accuracy of balance of payment data (improving diamond sector data and reducing errors and omissions) and quarterly national accounts and the timeliness of fiscal data are needed to better assist policy formulation.

\section{Box 2. Botswana: Investment Scaling Up Scenario}

In preparing the $11^{\text {th }}$ National Development Plan, the authorities will be considering ways to promote physical and human capital formation by scaling-up investments in public infrastructure and education, with the ultimate goal of diversifying the economy and fostering inclusive growth.

In an alternative scenario using the DIGNAR1 (Debt, Investment, Growth and Natural Resources) model (calibrated to reflect features of Botswana), staff simulated the macroeconomic effects of scaling up public investment. The impact of the scaling-up depends on the strength of complementary reforms to improve the efficiency of public investment and the business environment. These factors affect the quality and effectiveness of public capital, the return on investment, and ultimately growth. The simulations show that, under such reforms and a gradual process that raises investment in infrastructure to up to 12 percent of GDP over the medium-term, the growth rate of non-mineral real GDP could increase, on average, by an additional 1.2 percentage points per year compared to the baseline (private consumption would also be higher). Financing needs could be accommodated using diamond revenues and a portion of Pula Fund reserves, a modest amount of debt, rationalized government spending, and revenue mobilization. The analysis also shows that a more aggressive, front-loaded scaling-up, would be counterproductive, as it will run into absorptive capacity constraints and reduce the efficiency of investment and its overall impact.

\section{Scaling-up of Public Investment and Improved Efficiency and Productivity}
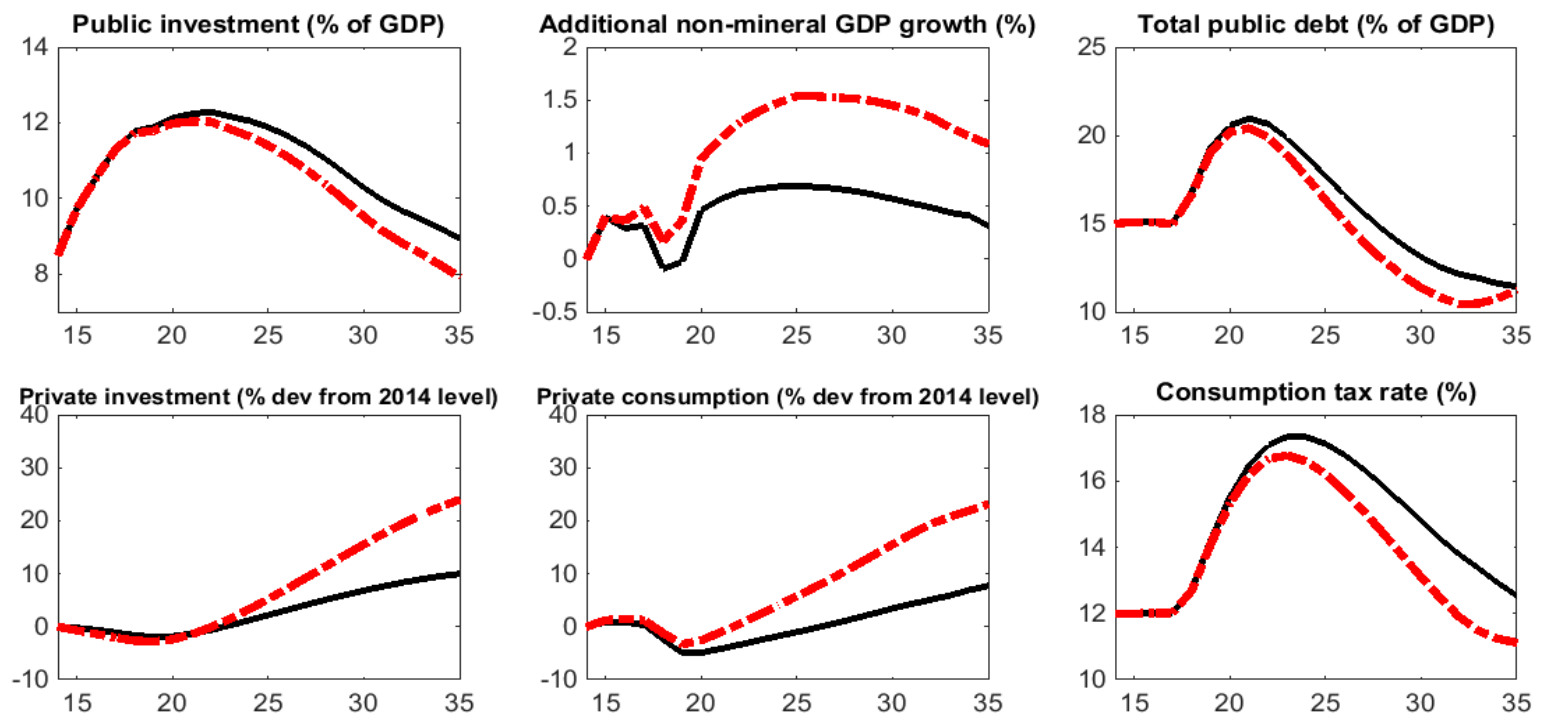

Scaling-up scenario (Efficiency $60 \%$, Return to public investment 15\%)

- With improved efficiency and productivity (Efficiency $80 \%$, Return to public investment $20 \%$ )

Source: IMF staff estimates and projections.

1. DIGNAR (Debt, Investment, Growth and Natural Resources) is a dynamic macroeconomic framework for analyzing the effects of public investment scale-ups in resource-rich economies, capturing features such as investment inefficiencies, limited absorptive capacity, and important complementarities between public and private investment ("Debt Sustainability, Public Investment, and Natural Resources in Developing Countries: the DIGNAR model", by Melina G., S. Yang, and L.F. Zanna, IMF Working Paper No. 14/50, 2014). In this simulation, the model was extended to account for foreign direct investment. 


\section{STAFF APPRAISAL}

\section{The authorities are well positioned to counteract the effects of the current downturn.}

The economy rapidly decelerated in 2014-2015 owing to the decline in the global demand for diamonds and copper, but successful monetary and financial policies kept inflation in check and the financial sector stable. With a strong external position, large fiscal buffers, and subdued inflation, Botswana is well positioned to weather the impact of a temporary decrease in export prices through a supportive policy mix.

38. The economy is expected to recover, although there are risks. A gradual economic recovery is projected for the next three years, based on the assumption of a measured increase in diamond prices and the effect of the authorities' fiscal stimulus program. There are risks, however, that the recovery in global diamond demand could be slow or protracted and that the increase in public investment may lead to some resources being squandered or not generate enough impetus on aggregate demand, leading to weak economic activity. These risks underscore the need for decisive steps to avoid projects with uncertain returns, resolve the energy and water crises, and deregulate the business environment.

39. Revenue mobilization will be important. The weakening of the fiscal accounts due to reduced mineral receipts has been compounded by lower SACU revenues, and prospects for a quick recovery of the latter are bleak. In this regard, the authorities need to move forward with a review of tax administration, reform the system of property taxation in line with previous technical assistance, and streamline exemptions. Reforms in these areas stand to deliver enough gains to protect Botswana's fiscal buffers and help fund future budgets. Should these reforms prove insufficient cushion against subdued or possibly lower mining and SACU revenues in coming years, consideration could be given to increasing the value-added tax rate.

\section{The Bank of Botswana's plans to strengthen the financial system are welcomed.}

The financial system remains sound and the Bank of Botswana's supervision capacity is strong, but in the context of a slowdown in the economy heightened monitoring of the sector is warranted, including through on-site supervisory reviews of systemic institutions, a stress test to assess households' debt servicing capacity, and implementation of Basel II requirements. Over time, a formal macro-prudential framework can be usefully developed.

41. The staff supports the authorities' plans to take sufficient time to work on the NPD 11 this year to rethink Botswana's development strategy and encourages the authorities to focus on the following priorities:

$>$ Ensure that the envisaged investments in the energy and water sectors are timely executed and that there is accountability among responsible bodies, including the SOEs in charge of service delivery. Plans to introduce regulatory agencies are welcomed, but provisions will be needed to ensure that they have the necessary technical capacity and are fully independent. In addition, the 
staff welcomes the authorities' intentions to move forward with plans to develop solar energy capacity and encourages them to actively involve the private sector in the process.

$>$ Strengthen the framework for managing mineral revenues by considering a fiscal rule and clarifying the links with the Pula Fund and the budget process. One option could be a rule based on the non-mineral primary fiscal balance that could establish appropriate targets to be achieved by the end of each NDP cycle.

> Undertake an expenditure review of the largest ministries and a Public Investment Management Assessment to identify savings, capacity constraints, and a target rate for scaling up public investment. This could help improve efficiency of government services and formulate a public investment plan in the context of the medium-term fiscal framework with a set of wellprioritized projects based on expected costs and returns.

$>$ Another key priority is to lower unemployment. In this regard, the authorities should proceed to implement their time-bound action plan to improve the business environment, especially to streamline registration of new businesses, reduce red tape on construction permits, and expedite reforms on access to credit and information. Similarly, enhancement of existing training programs and investments in education will be important, but they should be complemented with less onerous restrictions on work permits for skilled foreign workers as a way to raise productivity and promote transfer of skills to local workers.

$>$ Advance plans to improve the efficiency and profitability of SOEs and involve the private sector in the process; and

Proceed slowly on the strategy to set up economic zones by waiting until enough lessons and results from the experience with one or two zones are available to decide whether to proceed with the rest, avoiding costly tax incentives, and ensuring that the business environment in the zones is sufficiently improved (especially by removing restrictions on foreign work permits).

\section{The staff recommends that the Article IV consultation with Botswana be held on the standard 12-month cycle.}


Table 1. Botswana: Key Issues From Previous Article IV Consultations

\begin{tabular}{|c|c|}
\hline $\begin{array}{c}\text { IMF } 2013 \text { \& } 2014 \text { Article IV } \\
\text { Recommendations }\end{array}$ & Authorities' Response \\
\hline $\begin{array}{l}\text { - Consolidate fiscal policy and rebuild } \\
\text { fiscal buffers. } \\
\text { - Develop medium term expenditure } \\
\text { framework (MTEF). }\end{array}$ & $\begin{array}{l}\text { The budget } r \text { recorded large fiscal surpluses in FY2013/14 and } \\
\text { FY2014/15 ( } 5.6 \text { and } 2.5 \text { percent of GDP, respectively), consistent with } \\
\text { staff advice. } \\
\text { The FY2014/15 budget for the first time included medium term } \\
\text { projection of government accounts-in line with staff advice. } \\
\text { Ministries are also undergoing a budgeting exercise with the goal of } \\
\text { informing the medium term budget framework expenditure ceilings. } \\
\text { Further progress with the MTEF is hampered by capacity constraints, } \\
\text { requiring continued TA support. }\end{array}$ \\
\hline $\begin{array}{l}\text { - Rationalize state owned enterprises } \\
\text { (SOE). } \\
\text { - Contain the wage bill. }\end{array}$ & $\begin{array}{l}\text { Profitability in a number of Public Enterprises has improved and the } \\
\text { long-awaited IPO of Botswana Telecommunication Corporation was } \\
\text { launched in December 2015. A number of SOEs, however, continue } \\
\text { to register significant losses. } \\
\text { Progress in this area has been elusive, with the wage bill remaining at } \\
12-13 \text { percent of GDP in recent years. The draft } 2016 / 17 \text { budget } \\
\text { represents the first effort to contain the wage bill by reducing non- } \\
\text { salary wage components (e.g. missions, overtime). }\end{array}$ \\
\hline - Broaden the tax base. & $\begin{array}{l}\text { Income taxes and taxes on goods and services as a share of non- } \\
\text { mining GDP have remained virtually unchanged or declining in } \\
\text { recent years, underscoring the need for renewed reforms in this area. }\end{array}$ \\
\hline $\begin{array}{l}\text { - Strengthen regulation and } \\
\text { supervision of nonbank financial } \\
\text { institutions. } \\
\text { - } \quad \text { Enhance monitoring of commercial } \\
\text { banks' exposure to households and } \\
\text { consider macro prudential measures } \\
\text { to limit the growth rate of household } \\
\text { borrowing and the associated risks to } \\
\text { financial stability. } \\
\text { Establish credit bureau arrangements } \\
\text { following international best practices } \\
\text { Develop a reliable property market } \\
\text { index to help monitor price } \\
\text { developments and take appropriate } \\
\text { regulatory steps where needed. }\end{array}$ & $\begin{array}{l}\text { The authorities continue to strengthen NBFIRA's skill base and } \\
\text { regulatory infrastructure with the assistance from the MCM TA. } \\
\text { The authorities have not introduced macro-prudential tools but } \\
\text { credit growth has declined significantly making the introduction of } \\
\text { macro-prudential tools unnecessary at this stage. } \\
\text { Reform of the legislation governing credit bureaus has not been } \\
\text { completed yet. } \\
\text { The BoB has subscribed a quarterly report on the property market } \\
\text { that includes information on price developments and is currently } \\
\text { working on a property price index for Botswana. }\end{array}$ \\
\hline
\end{tabular}


Table 2. Botswana: Selected Economic and Social Indicators, 2012-20

\begin{tabular}{|c|c|c|c|c|c|c|c|c|c|}
\hline & 2012 & 2013 & 2014 & 2015 & 2016 & 2017 & 2018 & 2019 & 2020 \\
\hline & & & & Prel. & & & jections & & \\
\hline & \multicolumn{9}{|c|}{ (Annual percent change, unless otherwise indicated) } \\
\hline \multicolumn{10}{|l|}{ National income and prices } \\
\hline Real GDP ${ }^{1}$ & 4.5 & 9.9 & 3.2 & -0.3 & 3.7 & 4.3 & 4.4 & 5.0 & 4.3 \\
\hline Mineral & -5.8 & 24.2 & 0.5 & -21.0 & -3.0 & 0.3 & 0.5 & 7.5 & 4.0 \\
\hline Nonmineral $^{2}$ & 6.4 & 7.4 & 3.7 & 3.6 & 4.7 & 4.8 & 4.9 & 4.6 & 4.3 \\
\hline Consumer prices (average) & 7.5 & 5.9 & 4.4 & 3.0 & 3.4 & 3.6 & 4.0 & 4.2 & 4.3 \\
\hline Diamond production (millions of carats) & 20.9 & 23.0 & 24.7 & 21.7 & 20.8 & 21.0 & 21.0 & 23.0 & 24.2 \\
\hline \multicolumn{10}{|l|}{ External sector } \\
\hline Exports of goods and services, f.o.b. (US\$) & -7.4 & 28.8 & 7.8 & -29.4 & 5.5 & 9.3 & 9.5 & 14.6 & 6.9 \\
\hline Of which: diamonds & 7.1 & 39.0 & 10.4 & -34.4 & 7.7 & 10.5 & 10.7 & 17.6 & 7.0 \\
\hline Imports of goods and services, f.o.b. (US\$) & 7.4 & 3.4 & -4.3 & -20.7 & 13.2 & 6.3 & 6.6 & 5.3 & 5.2 \\
\hline Terms of trade & 18.0 & 29.7 & 8.5 & 1.8 & 12.8 & 1.6 & 2.6 & 0.8 & 0.7 \\
\hline Nominal effective exchange rate & -2.2 & -0.4 & -0.2 & 0.0 & $\ldots$ & $\ldots$ & $\ldots$ & $\ldots$ & ... \\
\hline \multirow[t]{2}{*}{ Real effective exchange rate } & 1.0 & 1.6 & 0.4 & 0.6 & $\ldots$ & $\ldots$ & $\ldots$ & $\ldots$ & ... \\
\hline & \multicolumn{9}{|c|}{ (Percentage change with respect to M2) } \\
\hline \multicolumn{10}{|l|}{ Money and banking } \\
\hline Net foreign assets & 0.2 & 16.8 & 21.2 & 12.5 & 7.1 & 15.6 & 18.6 & 30.5 & 32.0 \\
\hline Net domestic assets & 7.8 & -9.2 & -17.2 & -2.2 & 4.7 & -4.6 & -8.3 & -19.5 & -21.1 \\
\hline Broad money (M2) & 8.4 & 8.4 & 4.6 & 10.5 & 11.3 & 10.6 & 9.9 & 11.0 & 10.9 \\
\hline Velocity (GDP relative to M2) & 2.3 & 2.3 & 2.6 & 2.2 & 2.2 & 2.2 & 2.2 & 2.1 & 2.1 \\
\hline Velocity (nonmineral GDP relative to M3) & 1.8 & 1.8 & 1.9 & 1.9 & 1.9 & 1.9 & 1.9 & 1.9 & 1.9 \\
\hline \multirow[t]{2}{*}{ Credit to the private sector } & 13.6 & 9.8 & 10.2 & 6.3 & 7.3 & 7.2 & 7.1 & 8.1 & 7.9 \\
\hline & \multicolumn{9}{|c|}{ (Percent of GDP, unless otherwise indicated) } \\
\hline \multicolumn{10}{|l|}{ Investment and savings ${ }^{1}$} \\
\hline Gross investment (including change in inventories) & 38.1 & 32.9 & 30.6 & 27.8 & 29.4 & 30.4 & 31.3 & 33.3 & 34.9 \\
\hline Public & 7.8 & 7.0 & 8.4 & 10.2 & 9.7 & 10.3 & 9.9 & 9.3 & 9.1 \\
\hline Private & 30.4 & 25.8 & 22.2 & 17.6 & 19.7 & 20.1 & 21.4 & 24.1 & 25.8 \\
\hline Gross savings & 39.6 & 41.8 & 46.3 & 37.1 & 31.6 & 33.3 & 35.6 & 42.6 & 44.8 \\
\hline Public & 20.1 & 21.6 & 23.8 & 22.1 & 18.4 & 18.3 & 18.5 & 18.9 & 19.2 \\
\hline Private & 19.4 & 20.2 & 22.4 & 15.0 & 13.1 & 15.0 & 17.1 & 23.7 & 25.6 \\
\hline \multicolumn{10}{|l|}{ Central government finances ${ }^{2}$} \\
\hline Total revenue and grants & 36.2 & 38.0 & 39.6 & 36.8 & 31.3 & 31.3 & 30.4 & 30.6 & 30.3 \\
\hline Total expenditure and net lending & 35.4 & 32.4 & 35.8 & 39.7 & 35.2 & 34.3 & 31.9 & 30.3 & 29.3 \\
\hline Overall balance (deficit -) & 0.8 & 5.6 & 3.8 & -3.0 & -3.9 & -3.0 & -1.5 & 0.3 & 1.0 \\
\hline Non-mineral primary balance ${ }^{3}$ & -13.0 & -13.6 & -16.9 & -20.7 & -19.1 & -17.7 & -15.3 & -14.3 & -13.3 \\
\hline Total central government debt & 18.9 & 17.6 & 17.9 & 17.8 & 15.6 & 11.8 & 10.4 & 9.1 & 8.1 \\
\hline \multicolumn{10}{|l|}{ External sector } \\
\hline Current account balance & 0.3 & 8.9 & 15.7 & 9.3 & 2.2 & 2.9 & 4.3 & 9.3 & 9.8 \\
\hline Balance of payments & -0.8 & 1.1 & 8.0 & 2.4 & 5.1 & 6.6 & 7.2 & 12.8 & 13.5 \\
\hline External public debt ${ }^{4}$ & 19.2 & 17.8 & 17.1 & 18.3 & 16.1 & 14.5 & 12.8 & 11.3 & 10.0 \\
\hline \multirow[t]{2}{*}{ o/w public and publicly guaranteed } & 5.6 & 5.1 & 4.9 & 5.7 & 5.3 & 4.9 & 4.4 & 4.0 & 3.6 \\
\hline & \multicolumn{9}{|c|}{ (Millions of US\$, unless otherwise indicated) } \\
\hline Gross official reserves (end of period) & 7,617 & 7,768 & 8,313 & 7,500 & 8,130 & 9,060 & 10,078 & 11,999 & 14,162 \\
\hline Months of imports of goods and services ${ }^{5}$ & 10.0 & 10.6 & 14.4 & 11.4 & 11.7 & 12.2 & 12.9 & 14.7 & 16.9 \\
\hline Months of non-diamond imports ${ }^{5}$ & 14.8 & 15.9 & 18.8 & 15.5 & 16.0 & 16.9 & 18.8 & 21.6 & 24.8 \\
\hline Percent of GDP & 52.9 & 54.5 & 55.5 & 64.7 & 64.4 & 67.3 & 70.1 & 77.6 & 84.9 \\
\hline \multicolumn{10}{|c|}{ Sources: Botswana authorities and IMF staff estimates and projections. } \\
\hline \multicolumn{10}{|l|}{${ }^{1}$ Calendar year. } \\
\hline \multicolumn{10}{|l|}{${ }^{2}$ Year beginning April 1.} \\
\hline \multicolumn{10}{|c|}{$\begin{array}{l}{ }^{3} \text { The non-mineral primary balance is computed as the difference between non-mineral revenue and expenditure (excluding interest receipts and interest payments), } \\
\text { divided by non-mineral GDP. }\end{array}$} \\
\hline${ }^{4}$ Includes publicly guaranteed debt. & & & & & & & & & \\
\hline${ }^{5}$ Based on imports of goods and services for the follon & & & & & & & & & \\
\hline
\end{tabular}




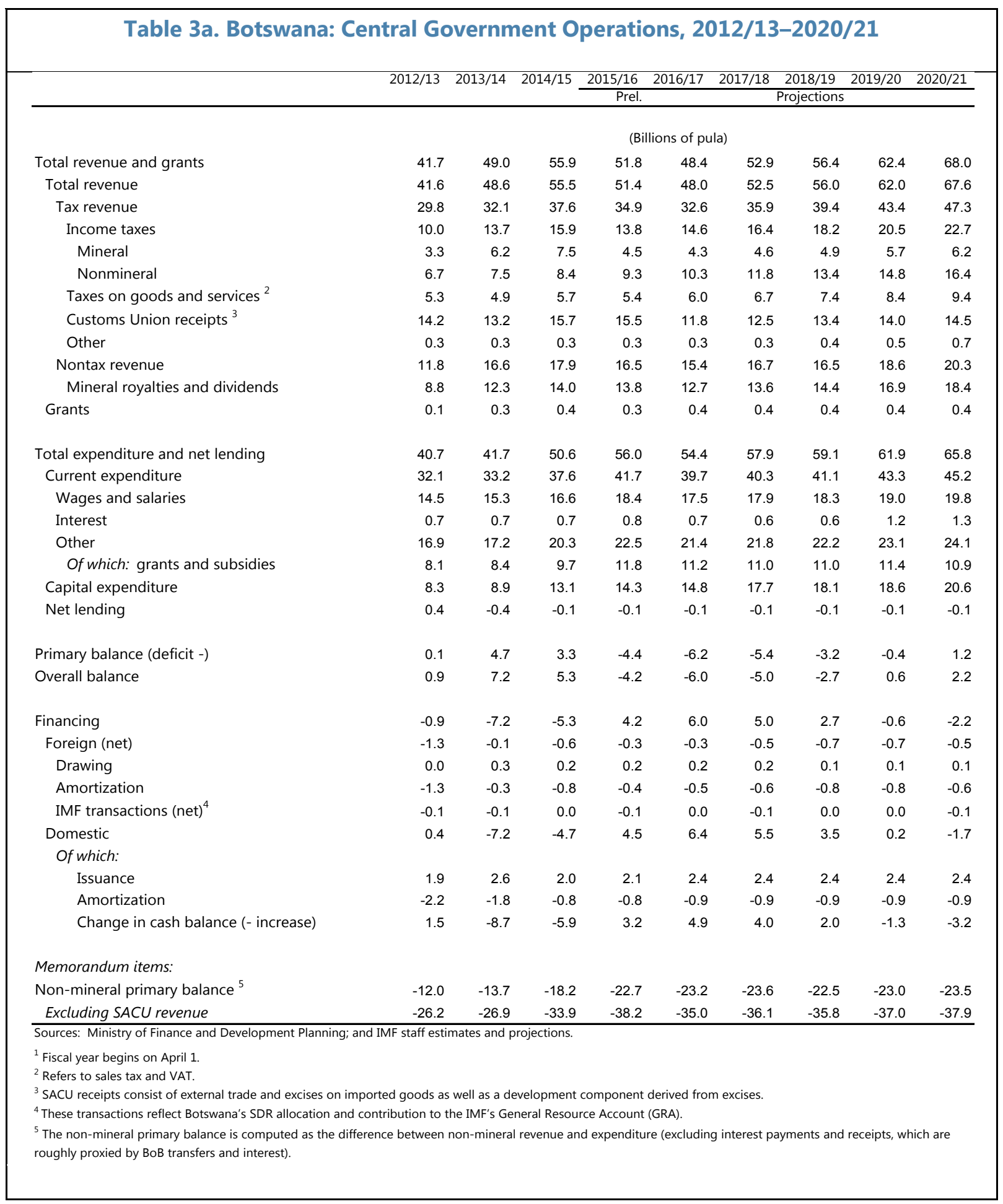


Table 3b. Botswana: Central Government Operations, 2012/13-2020/21

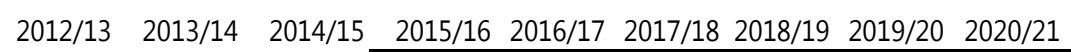
Prel. Projections

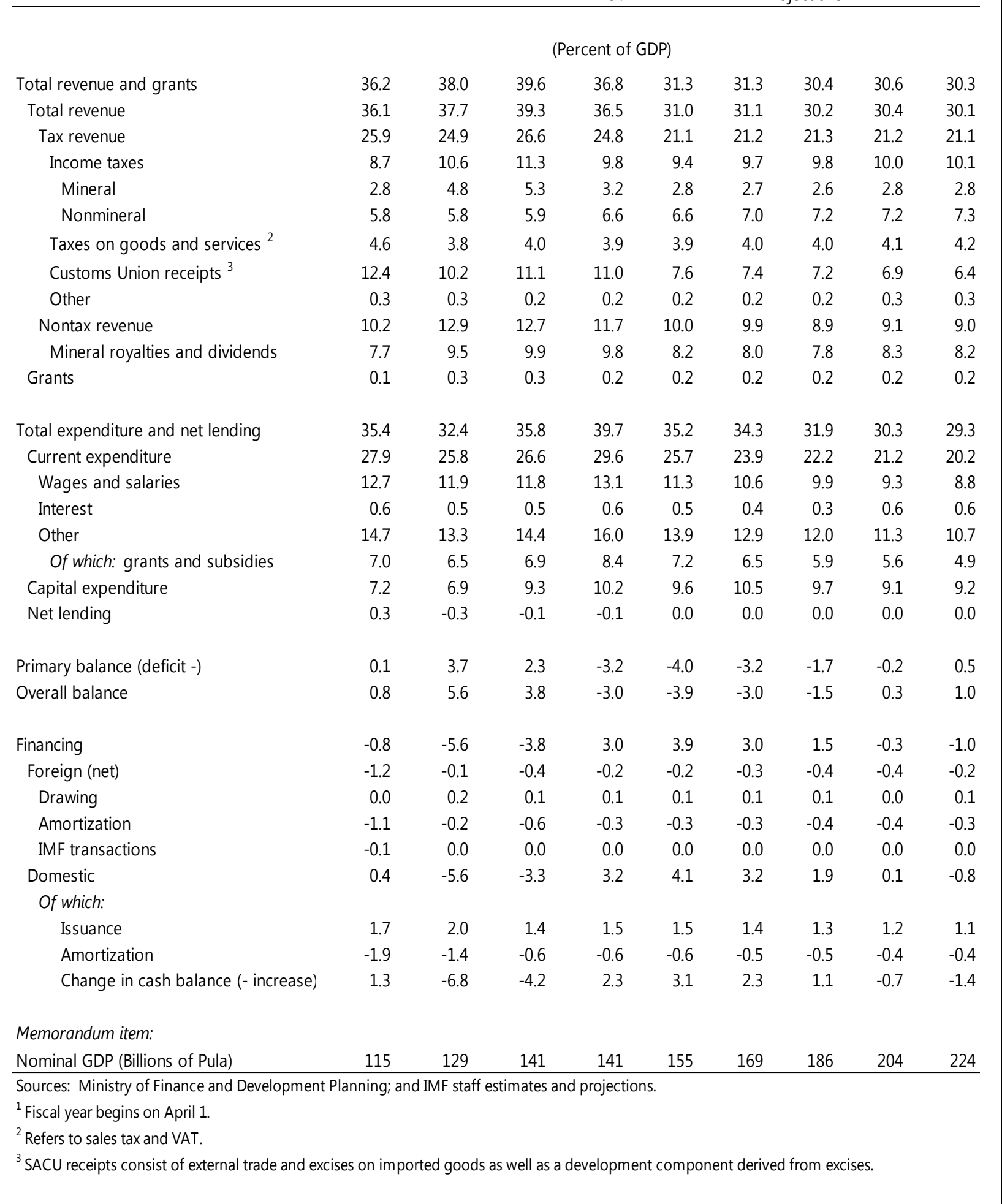




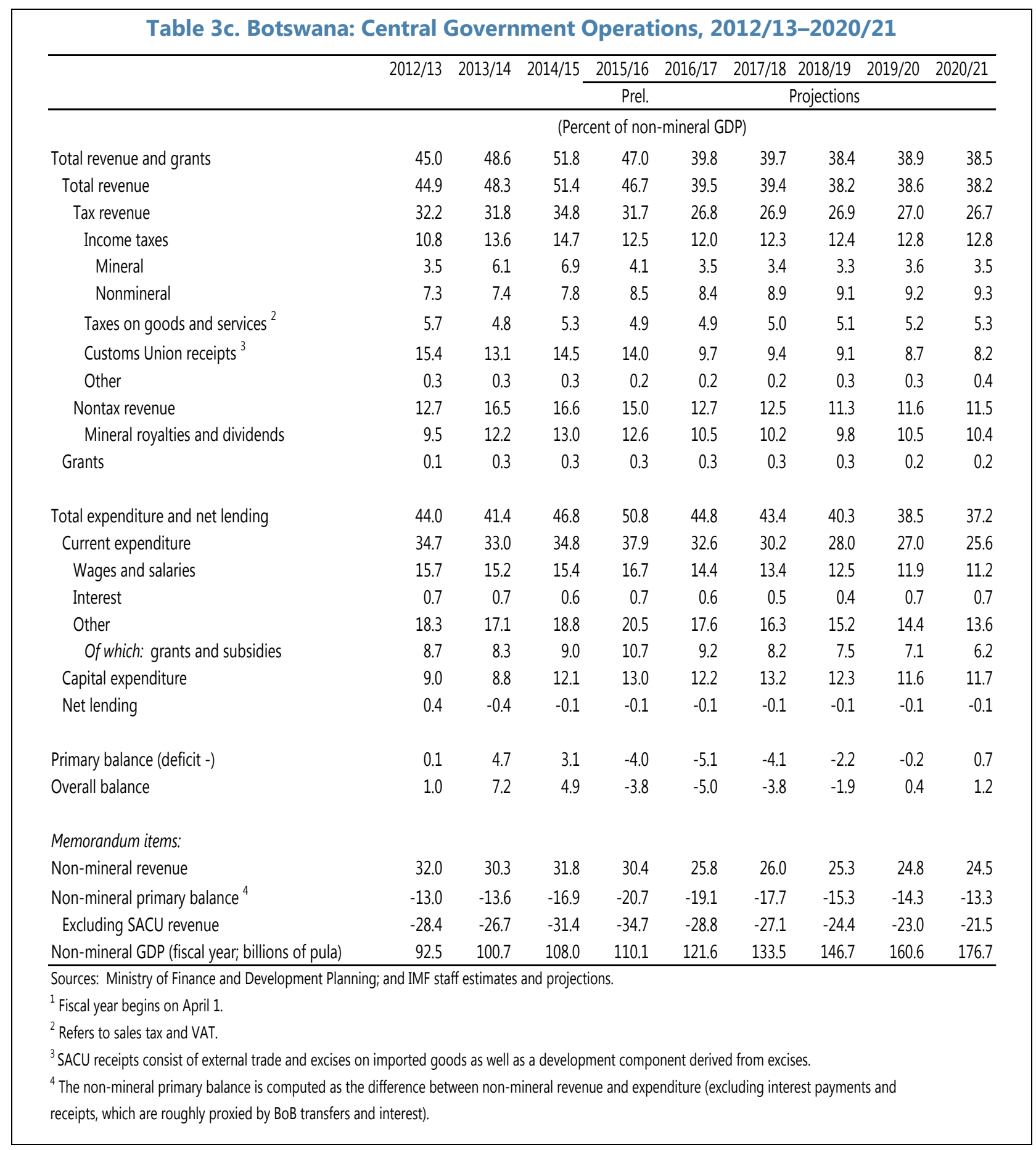




\begin{tabular}{|c|c|c|c|c|c|c|c|c|c|}
\hline \multicolumn{10}{|c|}{ Table 4. Botswana: Balance of Payments, 2012-2020 } \\
\hline & 2012 & 2013 & 2014 & 2015 & 2016 & 2017 & 2018 & 2019 & 2020 \\
\hline & & & & Prel. & \multicolumn{5}{|c|}{ Projections } \\
\hline & \multicolumn{9}{|c|}{ (US\$ millions, unless otherwise indicated) } \\
\hline Current account balance & 46 & 1,323 & 2,497 & 1,202 & 280 & 391 & 625 & 1,452 & 1,661 \\
\hline Trade balance & $-1,983$ & -337 & 542 & -568 & $-1,136$ & -971 & -795 & 2 & 180 \\
\hline Exports, f.o.b. & 6,041 & 7,931 & 8,538 & 5,794 & 6,137 & 6,750 & 7,440 & 8,634 & 9,250 \\
\hline Diamonds & 4,748 & 6,598 & 7,282 & 4,773 & 5,141 & 5,683 & 6,291 & 7,395 & 7,916 \\
\hline Other raw materials & 543 & 647 & 581 & 437 & 375 & 393 & 411 & 429 & 446 \\
\hline Other & 750 & 686 & 675 & 584 & 621 & 674 & 738 & 810 & 889 \\
\hline Imports, f.o.b & $-8,024$ & $-8,269$ & $-7,996$ & $-6,363$ & $-7,273$ & $-7,721$ & $-8,235$ & $-8,631$ & $-9,070$ \\
\hline Services & 241 & 349 & 578 & 596 & 634 & 655 & 691 & 706 & 732 \\
\hline Transportation & -103 & -80 & -17 & -17 & -16 & -16 & -16 & -17 & -17 \\
\hline Travel & 560 & 624 & 701 & 685 & 726 & 755 & 785 & 813 & 846 \\
\hline Other services & -216 & -195 & -107 & -72 & -77 & -84 & -78 & -90 & -97 \\
\hline Income & 44 & -376 & -346 & -319 & -323 & -352 & -375 & -392 & -405 \\
\hline Current transfers & 1,744 & 1,687 & 1,724 & 1,493 & 1,106 & 1,059 & 1,104 & 1,137 & 1,153 \\
\hline SACU receipts & 1,677 & 1,601 & 1,679 & 1,453 & 1,066 & 1,016 & 1,059 & 1,088 & 1,100 \\
\hline Capital and financial account & 200 & -965 & 296 & 252 & 362 & 512 & 428 & 547 & 613 \\
\hline Capital account & 0 & 0 & 0 & 0 & 0 & 0 & 0 & 0 & 0 \\
\hline Financial account & 200 & -965 & 296 & 252 & 362 & 512 & 428 & 547 & 613 \\
\hline Direct investment & 480 & 314 & 404 & 378 & 382 & 440 & 484 & 522 & 567 \\
\hline Portfolio investment & -175 & $-1,244$ & -79 & -70 & -66 & -68 & -69 & -71 & -73 \\
\hline Other investment & -104 & -35 & -29 & -56 & 46 & 140 & 13 & 96 & 119 \\
\hline Assets & -275 & 31 & -113 & -186 & -84 & 17 & -84 & 0 & 0 \\
\hline Liabilities & 170 & -66 & 85 & 130 & 130 & 123 & 96 & 96 & 119 \\
\hline Net government long-term borrowing & -108 & -954 & -52 & -32 & -24 & -30 & -52 & -57 & -38 \\
\hline Other net private long-term borrowing & 65 & 95 & 66 & 59 & 57 & 52 & 52 & 52 & 50 \\
\hline Short-term borrowing & 121 & 119 & 119 & 103 & 97 & 101 & 96 & 101 & 107 \\
\hline Reserve assets (increase -) & 116 & -167 & $-1,272$ & -309 & -642 & -903 & $-1,053$ & $-1,999$ & $-2,274$ \\
\hline \multirow[t]{2}{*}{ Net errors and omissions } & -362 & -191 & $-1,521$ & $-1,763$ & $\ldots$ & $\ldots$ & $\ldots$ & $\ldots$ & $\ldots$ \\
\hline & \multicolumn{9}{|c|}{ (Percent of GDP, unless otherwise indicated) } \\
\hline Balance of payments & -0.8 & 1.1 & 8.0 & 2.4 & 5.1 & 6.6 & 7.2 & 12.8 & 13.5 \\
\hline Current account & 0.3 & 8.9 & 15.7 & 9.3 & 2.2 & 2.9 & 4.3 & 9.3 & 9.8 \\
\hline Trade balance & -13.5 & -2.3 & 3.4 & -4.4 & -8.9 & -7.1 & -5.5 & 0.0 & 1.1 \\
\hline Exports of goods & 41.1 & 53.5 & 53.8 & 45.1 & 48.3 & 49.6 & 51.0 & 55.2 & 54.8 \\
\hline Of which: diamonds & 32.3 & 44.5 & 45.9 & 37.1 & 40.5 & 41.8 & 43.2 & 47.3 & 46.9 \\
\hline Imports of goods & 54.6 & 55.8 & 50.4 & 49.5 & 57.3 & 56.7 & 56.5 & 55.2 & 53.7 \\
\hline Services balance & 1.6 & 2.4 & 3.6 & 4.6 & 5.0 & 4.8 & 4.7 & 4.5 & 4.3 \\
\hline Income and transfers balance & 12.2 & 8.9 & 8.7 & 9.1 & 6.2 & 5.2 & 5.0 & 4.8 & 4.4 \\
\hline Financial account & 1.4 & -6.5 & 1.9 & 2.0 & 2.9 & 3.8 & 2.9 & 3.5 & 3.6 \\
\hline Direct investment & 3.3 & 2.1 & 2.5 & 2.9 & 3.0 & 3.2 & 3.3 & 3.3 & 3.4 \\
\hline Portfolio investment & -1.2 & -8.4 & -0.5 & -0.5 & -0.5 & -0.5 & -0.5 & -0.5 & -0.4 \\
\hline \multirow[t]{2}{*}{ Other investment } & -0.7 & -0.2 & -0.2 & -0.4 & 0.4 & 1.0 & 0.1 & 0.6 & 0.7 \\
\hline & \multicolumn{9}{|c|}{ (Annual percentage change, unless otherwise indicated) } \\
\hline Export volumes & -17.6 & 8.3 & 4.4 & -21.7 & 6.1 & 5.2 & 5.0 & 12.5 & 4.3 \\
\hline Import volumes & 16.7 & 9.5 & 1.6 & -6.5 & 29.2 & 3.1 & 4.2 & 2.4 & 3.0 \\
\hline Terms of trade & 18.0 & 29.7 & 8.5 & 1.8 & 12.8 & 1.6 & 2.6 & 0.8 & 0.7 \\
\hline End-of-year reserves (US\$ millions) & $7,617.4$ & $7,767.6$ & $8,312.9$ & $7,500.0$ & $8,129.6$ & $9,060.4$ & $10,078.2$ & $11,999.1$ & $14,162.1$ \\
\hline 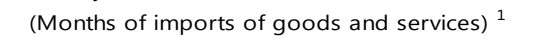 & 10.0 & 10.6 & 14.4 & 11.4 & 11.7 & 12.2 & 12.9 & 14.7 & 16.9 \\
\hline (Months of non-diamond imports) & 14.8 & 15.9 & 18.8 & 15.5 & 16.0 & 16.9 & 18.8 & 21.6 & 24.8 \\
\hline
\end{tabular}


Table 5. Botswana: Monetary Survey, 2012-2020

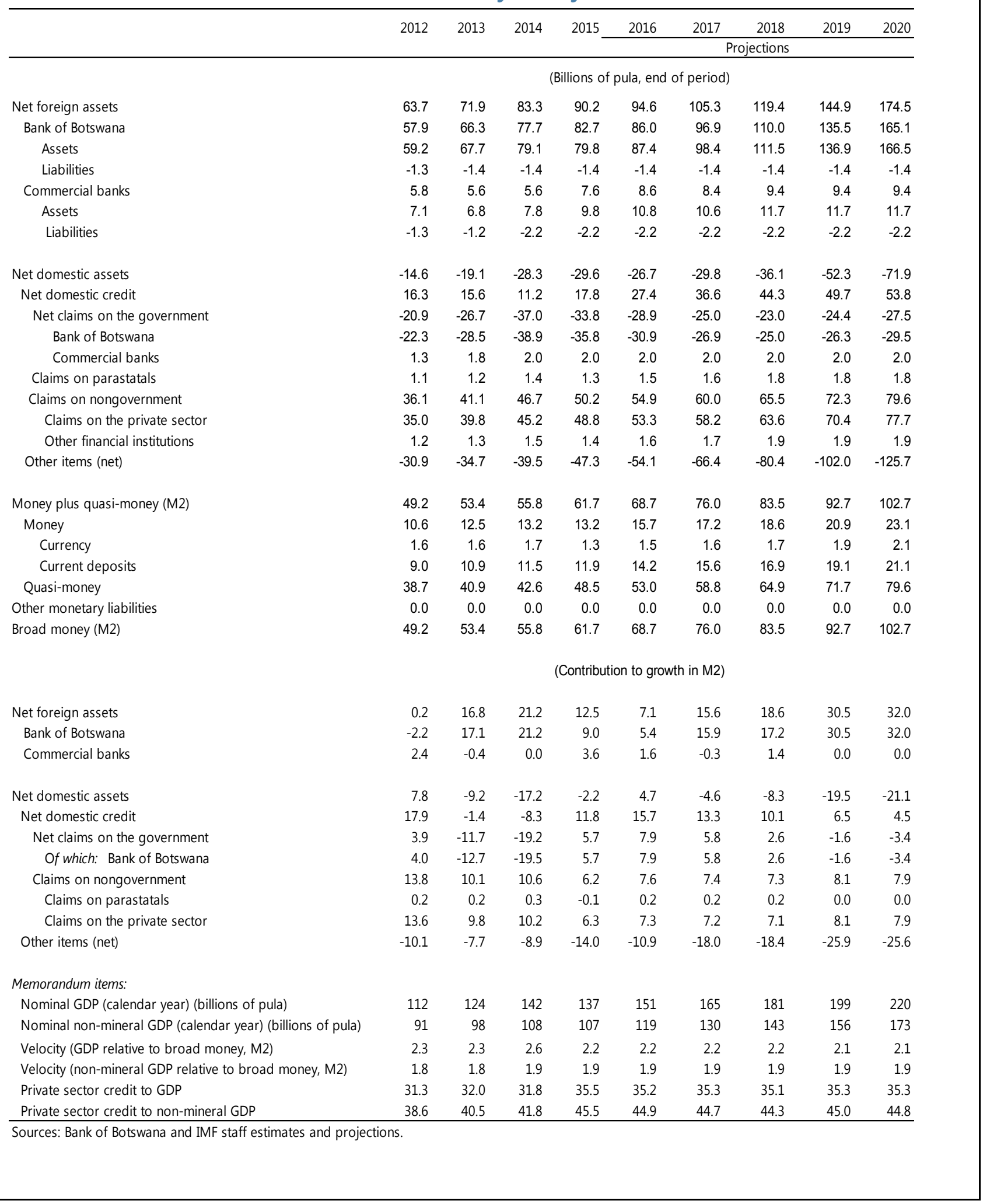


Table 6. Botswana: Financial Soundness Indicators, 2012-2015:Q3

$2012 \quad 2013 \quad 2014$ Mar-15 Jun-15 Sep-15

(Percent, unless otherwise indicated)

\section{Banking indicators}

Capital adequacy

Capital to assets

Regulatory capital to risk-weighted assets

$\begin{array}{llllll}11.9 & 11.3 & 11.3 & 10.3 & 11.0 & 10.8\end{array}$

Regulatory tier I capital to risk-weighted assets

$20.8 \quad 19.6$

$187-193$

$20.1 \quad 21.1$

Nonperforming loans net of provisions to capital

$12.3 \quad 13.4$

$13.1 \quad 13.0 \quad 14.5 \quad 14.2$

$4.3 \quad 9.8$

10.9

8.4

$13.9 \quad 14.3$

\section{Asset quality}

Large exposure to capital

Nonperforming loans to total gross loans

Bank provisions to nonperforming loans

$\begin{array}{rrrrrr}224.3 & 147.7 & 232.3 & 202.6 & 250.6 & 189.5 \\ 2.6 & 3.6 & 3.6 & 3.3 & 4.3 & 4.5 \\ 67.3 & 49.8 & 48.4 & 55.5 & 43.2 & 42.2\end{array}$

\section{Earnings and profitability}

Trading income to total income

Return on assets

Return on equity

$\begin{array}{llllll}5.7 & 3.5 & 3.4 & 5.0 & 5.9 & 5.4\end{array}$

$\begin{array}{llllll}1.2 & 3.7 & 2.8 & 1.3 & 3.4 & 1.9\end{array}$

Interest margin to gross income

Noninterest expenses to gross income

Personnel expenses to noninterest expenses

$\begin{array}{llllll}11.3 & 33.1 & 19.5 & 11.7 & 15.7 & 17.7\end{array}$

$\begin{array}{llllll}47.8 & 45.9 & 47.8 & 59.3 & 58.9 & 56.2\end{array}$

$\begin{array}{llllll}39.9 & 42.7 & 62.2 & 60.3 & 62.6 & 62.5\end{array}$

$\begin{array}{llllll}44.1 & 43.3 & 41.0 & 44.4 & 41.2 & 41.3\end{array}$

\section{Liquidity}

Liquid assets to total assets

Liquid assets to short-term liabilities

Customer deposits to total (non-interbank) loans

$\begin{array}{llllll}16.7 & 12.4 & 11.0 & 16.0 & 16.4 & 19.5\end{array}$

$\begin{array}{llllll}20.5 & 15.0 & 14.1 & 19.0 & 19.8 & 23.3\end{array}$

$\begin{array}{llllll}139.7 & 122.8 & 113.9 & 134.6 & 125.3 & 130.6\end{array}$

\section{Exposure to foreign exchange risk}

Net open position in foreign exchange to capital

Foreign currency-denominated loans to total loans

$-12.3$

$\begin{array}{lllll}-10.4 & -9.7 & -9.8 & -9.5 & -18.5 \\ 6.3 & 7.3 & 7.6 & 6.6 & 6.5\end{array}$

Foreign currency-denominated liabilities to total liabilities

$\begin{array}{rrrrrr}6.8 & 6.3 & 7.3 & 7.6 & 6.6 & 6.5\end{array}$

$\begin{array}{llllll}13.3 & 13.3 & 13.1 & 11.3 & 14.8 & 13.2\end{array}$

Sources: Bank of Botswana 


\begin{tabular}{|c|c|c|c|}
\hline \multicolumn{4}{|c|}{ Table 7. Botswana: Risk Assessment Matrix (RAM) ${ }^{1}$} \\
\hline Nature/source of main risks & $\begin{array}{l}\text { Likelihood of realization } \\
\text { in the next three years }\end{array}$ & Expected impact on economy if risk is realized & Possible Policy Response \\
\hline $\begin{array}{l}\text { Structurally weak growth in key advanced } \\
\text { and emerging economies. Weak demand } \\
\text { from a failure to fully address crisis } \\
\text { legacies and undertake structural } \\
\text { reforms, leading to low medium-term } \\
\text { growth and persisting financial } \\
\text { imbalances in the Euro area and Japan } \\
\text { (high likelihood). Easy global financial } \\
\text { conditions coming to an end and } \\
\text { insufficient reform progress undermine } \\
\text { medium-term growth in emerging } \\
\text { markets and prospects for commodity } \\
\text { prices (medium likelihood). }\end{array}$ & $\begin{array}{l}\text { HIGH for Advanced } \\
\text { Economies } \\
\text { MEDIUM for Emerging } \\
\text { Markets }\end{array}$ & $\begin{array}{l}\text { HIGH } \\
\text { Botswana's economy is sensitive to changes in } \\
\text { the global demand of diamonds which, in turn, is } \\
\text { affected by growth in advanced economies and } \\
\text { large emerging markets. } \\
\text { This could lead to sluggish growth and gradual } \\
\text { erosion of reserves buffers. Low commodity } \\
\text { prices would also hamper other mining activities } \\
\text { and related infrastructure. }\end{array}$ & $\begin{array}{l}\text { Short-term: countercyclical fiscal and } \\
\text { accommodative monetary policies } \\
\text { Medium-term: implement reforms to broaden the } \\
\text { domestic tax base, rationalize public expenditures, } \\
\text { and improve efficiency of government spending } \\
\text { and in state-owned enterprises. }\end{array}$ \\
\hline $\begin{array}{l}\text { Sluggish growth in South Africa, further } \\
\text { rand depreciation, and/or a revision in } \\
\text { the SACU revenue sharing formula could } \\
\text { lead to lower custom receipts. }\end{array}$ & HIGH & $\begin{array}{l}\text { MEDIUM } \\
\text { While not negligible, the impact on the fiscal and } \\
\text { external balances would be limited as the country } \\
\text { is not as heavily dependent on SACU receipts } \\
\text { compared to other SACU members. }\end{array}$ & $\begin{array}{l}\text { Domestic revenue mobilization reforms should be } \\
\text { accelerated, especially on VAT collection. } \\
\text { Government spending should be rationalized and } \\
\text { its efficiency improved through lower energy } \\
\text { transfers and strengthening of PFM. }\end{array}$ \\
\hline $\begin{array}{l}\text { Continued disruptions in electricity and } \\
\text { water provision. }\end{array}$ & $\begin{array}{l}\text { MEDIUM } \\
\text { Delays in planned projects } \\
\text { are possible given } \\
\text { recurrent difficulties in the } \\
\text { implementation of large } \\
\text { capital projects. }\end{array}$ & $\begin{array}{l}\text { HIGH } \\
\text { Private sector growth and economic } \\
\text { diversification will be adversely affected. }\end{array}$ & $\begin{array}{l}\text { Enhance implementation capacity in public } \\
\text { investment and enhance efficiency through } \\
\text { involvement of the private sector. }\end{array}$ \\
\hline $\begin{array}{l}\text { Deterioration in lenders' asset quality } \\
\text { driven by a deterioration of the } \\
\text { household loan portfolio. }\end{array}$ & LOW & $\begin{array}{l}\text { MEDIUM } \\
\text { Large concentration of banks' (and microlenders') } \\
\text { portfolios in the household segment make them } \\
\text { vulnerable to defaults, Lenders' deleveraging } \\
\text { could lead to lower lending to the private sector. }\end{array}$ & $\begin{array}{l}\text { Enhance supervision and regulation on banks and } \\
\text { NBFIs } \\
\text { Enhance capacity to monitor systemic risk build-up } \\
\text { Improve regulation of credit bureaus }\end{array}$ \\
\hline $\begin{array}{l}{ }^{1} \text { The Risk Assessment Matrix (RAM) shows ev } \\
\text { the baseline ("low" is meant to indicate a prob } \\
{ }^{2} \text { Based on the latest G-RAM (January 2016). }\end{array}$ & . & 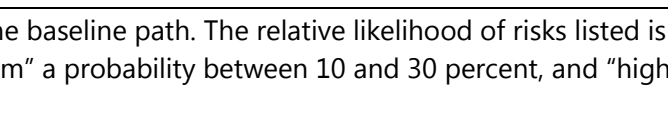 & $\begin{array}{l}\text { staff's subjective assessment of the risks surrounding } \\
\text { orobability of } 30 \text { percent or more). }\end{array}$ \\
\hline
\end{tabular}




\section{Appendix I. International Reserve Adequacy}

Botswana's international reserves exceed their adequate level by a wide margin according to the IMF's metric. Given the country's volatile and uncertain foreign exchange receipts, the authorities need to continue monitoring reserve adequacy and implementing policies that make a judicious use of revenues from non-renewable resources.

\section{A. Introduction}

1. Despite decreasing from its peak in 2001, Botswana's international reserve cover remains quite high. At end 2015, reserves stood at about US $\$ 7.5$ billion, equivalent to 65 percent of GDP and about 12 months of imports. ${ }^{1}$ Under the baseline projections, import coverage is projected to improve over time as real diamond prices are expected to gradually return to their long-term average.

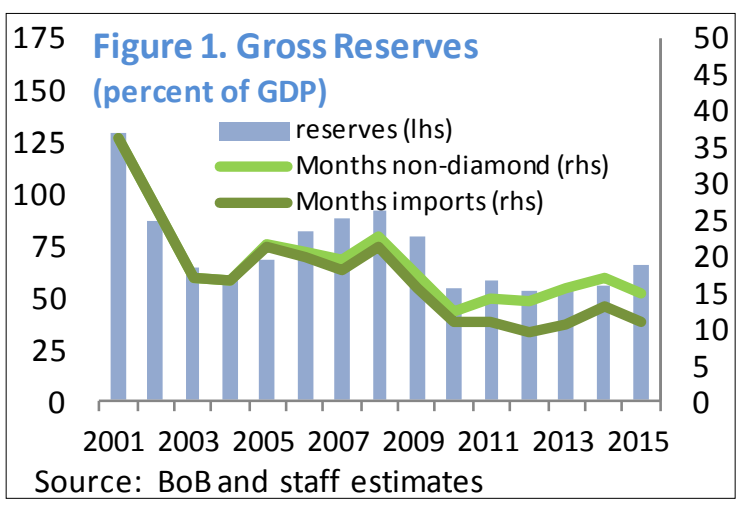

\section{B. Reserve Adequacy}

2. Traditional metrics of reserve adequacy are narrowly based and may provide conflicting signals. Simple rules of thumb - such as three months of imports, full cover of short-term debt plus debt service, or twenty percent of broad money- are attractive for their simplicity, but are rather arbitrary and only focus on one aspect of vulnerability. Since a balance of payments crisis can arise from a variety of sources, the IMF's metric is a risk-weighted measure based on observed outflows in previous events concerning exchange market pressures. ${ }^{2}$

\footnotetext{
${ }^{1}$ The authorities measure reserve coverage in months of current year imports of goods and services excluding diamond imports for re-exporting purposes (which would yield about 16 months of imports at end 2015). This measure, however, could overstate the coverage because next year's imports are typically higher than current year's imports and because, even if re-exported, diamond imports need to be paid with foreign currency.

${ }^{2}$ See further details in IMF (2011, 2013 and 2014).
} 
3. The IMF's metric for market access countries encompasses different sources of risk, such us external liabilities, trade, and measures of potential capital flight. ${ }^{3}$ More specifically, it uses variables to capture four specific sources of risk: (i) export earnings as a measure of the potential loss that could arise from a terms of trade shock; (ii) short term debt at remaining maturity (short term debt plus debt service) as a way to reflect liquidity (rollover) risk; (iii) portfolio investments plus medium and longterm debt to account for drains caused by non-residents' investment; and (iv) broad money as a proxy for resident capital flight. Other sources of risk, such as derivative exposures or exchange rate misalignments are not incorporated due to data limitations.

4. The weights of these sources of risk on the IMF's metric for market access countries are based on observed outflows during past periods of exchange market pressures. More specifically, annual distributions of percentage changes for each of the items discussed above during periods of exchange market pressures are computed. ${ }^{4}$ For each item, the metric takes the drains observed at the tenth percentile of the distribution. Separate distributions are estimated for countries with fixed exchange rates or with capital controls. Additional buffers are suggested for countries where commodity exports account for more than 50 percent of total exports. In Botswana commodity exports account for about 80 percent of the exports of goods and services (over 90 percent of exports of goods). However, the IMF's proposed methodology for commodity exporters relies on future contract prices, which are not available for diamonds. Nonetheless, taking into account the decrease in exports due to the drop in diamond prices in 2009 and 2015, staff considers that a weight of 25 percent for exports could be more adequate for Botswana to reflect the high volatility of diamond prices. The weights for countries with a fixed exchange rate are ${ }^{5}$ :

\begin{tabular}{ccccc|}
\multicolumn{1}{c}{} & \multicolumn{1}{c}{$\begin{array}{c}\text { Short-term } \\
\text { Debt }\end{array}$} & $\begin{array}{c}\text { Other } \\
\text { Liabilities }\end{array}$ & $\begin{array}{c}\text { Broad } \\
\text { Money }\end{array}$ & Exports \\
\cline { 2 - 5 } Weights & $30 \%$ & $20 \%$ & $10 \%$ & $10 \%$ \\
\cline { 2 - 5 } & & &
\end{tabular}

\section{Results}

5. Botswana's international reserves far exceed their adequate level according to the IMF's metric for market access countries. Reserves on the range of 100-150 percent of the composite metric are considered to be appropriate. For Botswana, this corresponds to reserves of 15 to 22 percent of GDP, compared to the current level of 65 percent of GDP. Using a more conservative weight of 25 percent

\footnotetext{
${ }^{3}$ A specific methodology is employed for low income countries without market access, where current account shocks dominate capital account shocks. This alternative methodology is not as relevant for Botswana, which is an upper middle income country with market access, and an open capital account (with substantial inflows and outflows). Botswana has not issued external debt although it has investment grade ratings from both S\&P (A- stable) and Moody's (A2 stable).

${ }^{4}$ As in Eichengreen et. al. (1997), an exchange market pressure index is constructed as a weighted average of reserve losses, exchange rate depreciation, and increases in interest rates. An episode of exchange market pressure occurs when the index deviates more than 1.5 times its standard deviation from the average.

${ }^{5}$ Botswana's Pula is pegged to a basket of currencies that comprises the South Africa's rand and the SDR with equal weights. While this is not a fixed exchange rate regime, its operational details seems to be closer to it than to a flexible exchange rate regime. In any case, using the weights for flexible exchange rates would, by design, yield a lower level of adequate reserves compared to the weights for fixed exchange regimes.
} 
for exports to incorporate the country's dependence on diamond prices, reserves of 20 to 30 percent of GDP would be deemed adequate. In this case, the current level of reserves would still be more than twice compared to the upper bound of the adequate range. ${ }^{6}$ Moreover, for the past twenty years the level of reserves has far exceeded the upper bound of the adequacy range. ${ }^{7}$
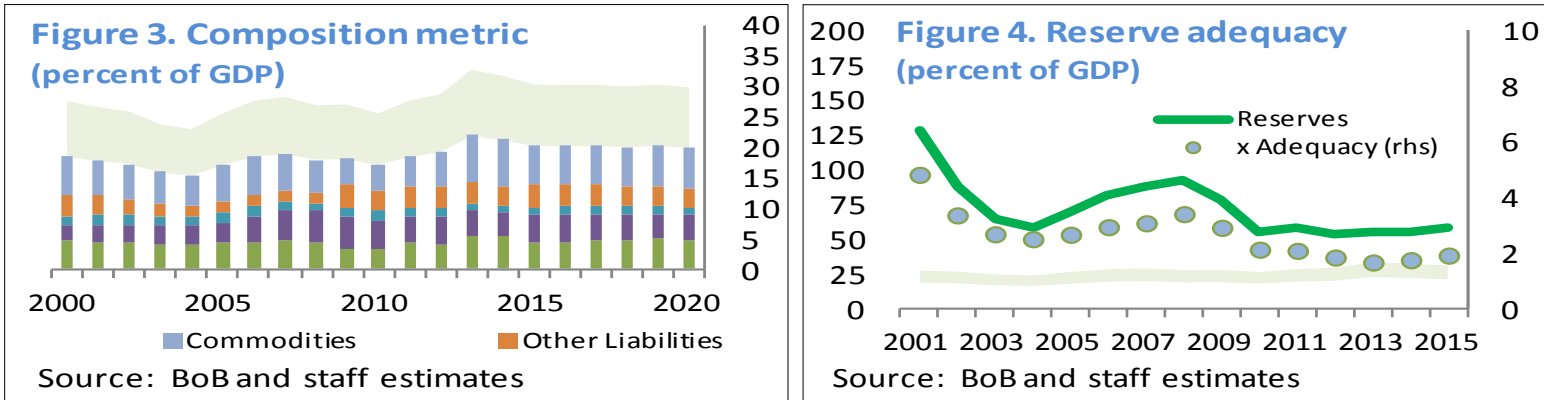

6. Regarding foreign reserves, the rules of the Pula Fund could be usefully clarified. At present, foreign reserves serve two goals: being a short run liquidity buffer and a sovereign wealth fund (that stores savings for future generations and for public investment) at once, with about $2 / 3$ of international reserves accounted by the Pula Fund (the rest corresponds to the liquidity portfolio). Within the Pula Fund, 1/3 is owned by the Bank of Botswana $(B \circ B)$ and the rest by the government. The authorities could consider clarifying the purpose, ownership and rules for withdrawals by the government of the Pula Fund (from the government's investment account). They could also consider clarifying the ownership structure and reviewing the asset allocation strategy, i.e. the liquidity portfolio should be solely owned by the BoB and used for countercyclical purposes, and part of the reserves in the Pula Fund could potentially be invested in longer-term instruments (given the goal to generate income for future generations) and achieve higher average returns.

7. In any case, the authorities need to continue implementing policies that maintain sufficient reserve buffers and preserve wealth for future generations. Given the volatility of diamond receipts, the risk of lower SACU transfers, and diamond exhaustibility, the authorities need to continue monitoring reserve adequacy and ensure a foreign reserves buffer for stabilization purposes of at least 20 percent of GDP. Lastly, capacity constraints limit the scope for the authorities to embark on a fast program of public investments, implying that a sizable amount of resources should be kept at the Pula Fund, with any withdrawals from it obeying to a well-prioritized investment plan embedded in a medium-term fiscal framework.

\footnotetext{
${ }^{6}$ International reserves are composed of the liquidity portfolio, which covers six months of current year non-diamond imports, and the Pula Fund which is owned by the government and the central bank. The size of the liquidity portfolio falls within the adequacy range according to the IMF's metric (about 5 to 8 months of current year nondiamond imports of goods and services). Which means that the excess reserves, compared to the IMF's metric, are kept in the Pula Fund.

${ }^{7}$ The authorities concurred with the staff assessment in the previous two Article IV consultations that foreign reserves exceeded their adequate level.
} 


\section{References}

International Monetary Fund. (2013). "The External Balance Approach." 


\section{Appendix II. External Stability Assessment}

Botswana's real effective exchange rate seems to be broadly in line with the level that would be consistent with its fundamentals. However, the assessment should be taken with caution considering uncertainties about the evolution of export prices.

\section{A. Introduction}

1. Botswana's external current account (CA) balance had steadily recovered after 2009 but deteriorated in 2015. The behavior of the CA closely follows the gyrations in the global diamond market. The surplus of 16 percent of GDP observed in 2014 was close to the peak of 19 percent in 2006, but in 2015 the surplus is estimated to have returned close to the level of 9 percent observed in 2013. The baseline scenario projects a gradual recovery in diamond prices and output (over the years, diamond prices are projected to revert to their long-term average), although a protracted period of sluggishness in global demand cannot be ruled out.
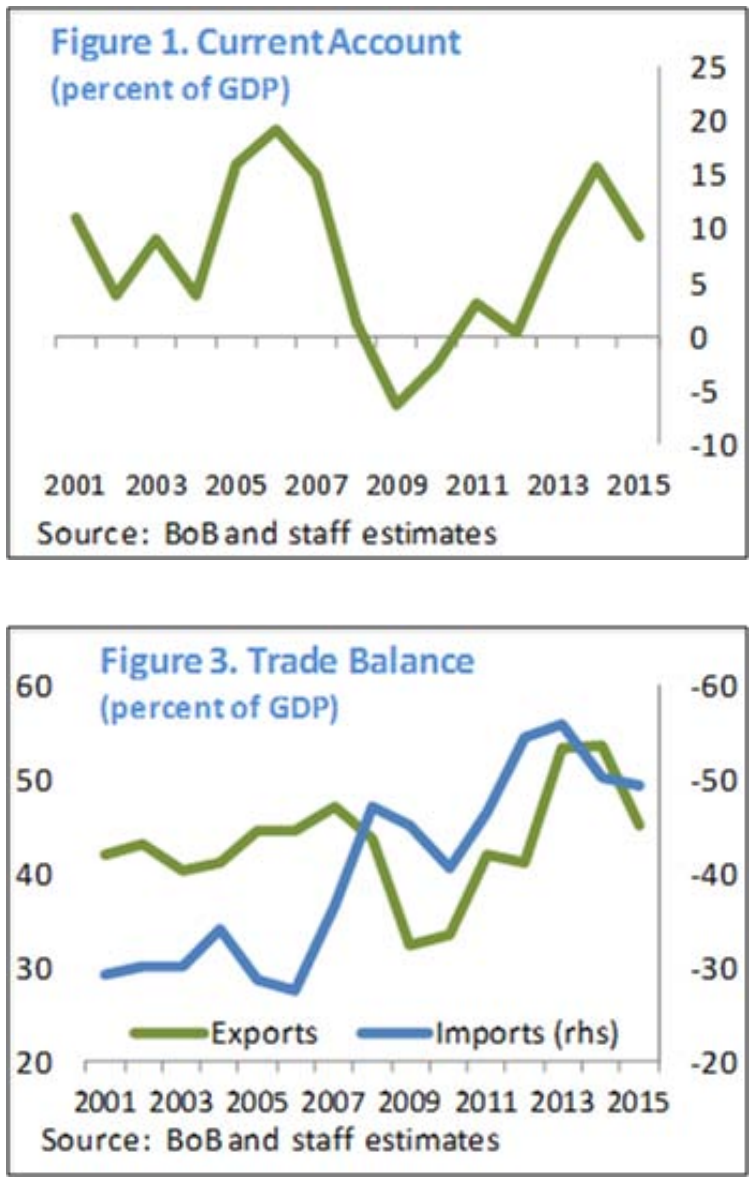
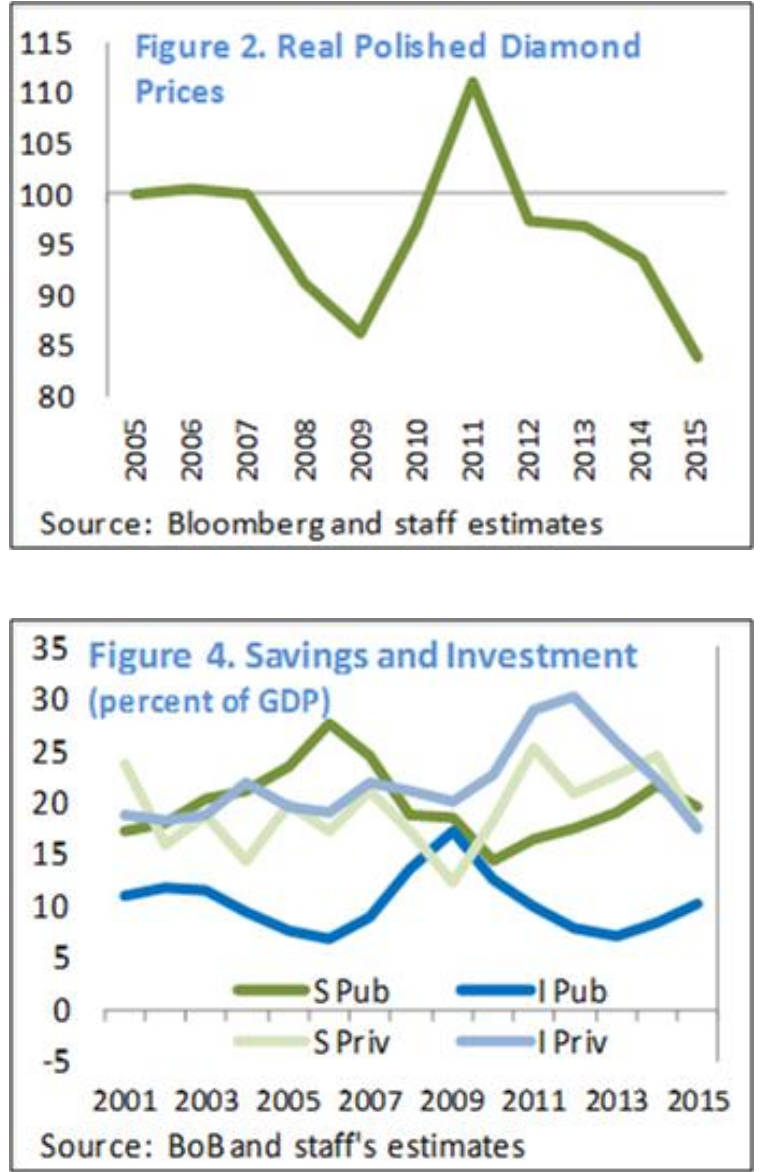
2. A savings and investment decomposition suggests that, historically, public finances have been closely linked to changes in the CA. This will likely be the case also in 2016 and 2017, as the government proceeds to implement its stimulus program which is associated with a continued fiscal deficit and will thus constrain the recovery in the current account.

3. Variations in the financial account have mostly depended on the behavior of portfolio investments. Net foreign direct investment (FDI) has been typically positive and stable and also associated with the mining sector (which accounts for about 80 percent of total FDI). Gross external financing requirements have remained broadly stable at about 24 percent of GDP since 2009 (about one-fourth of was of a short-term nature).

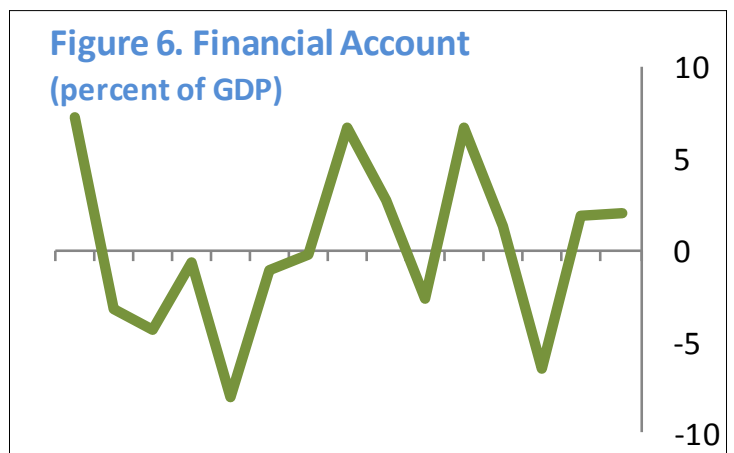

20012003200520072009201120132015

Source: BoB and staff estimates

4. In the past decade, Botswana's real effective exchange rate (REER) has appreciated by about 10 percent, with the Pula appreciating vis-a-vis the rand in nominal terms and depreciating vis-a-vis the U.S. dollar. Changes in the REER have been modest, likely because of the BoB's exchange rate policy to adjust the value of the Pula (crawling peg) based on expected inflation differentials with major trading partners and basket weights (comprising the SDR and South African rand in equal proportions) in line with its goal to support export-oriented economic development by limiting medium-term fluctuations and an excessive appreciation of the REER during export booms. At present, the REER is just about 4 percent above its 10-year average,

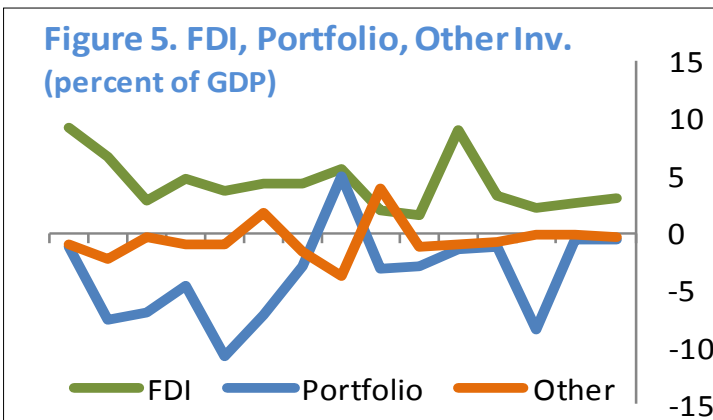

20012003200520072009201120132015 Source: BoB and staff estimates

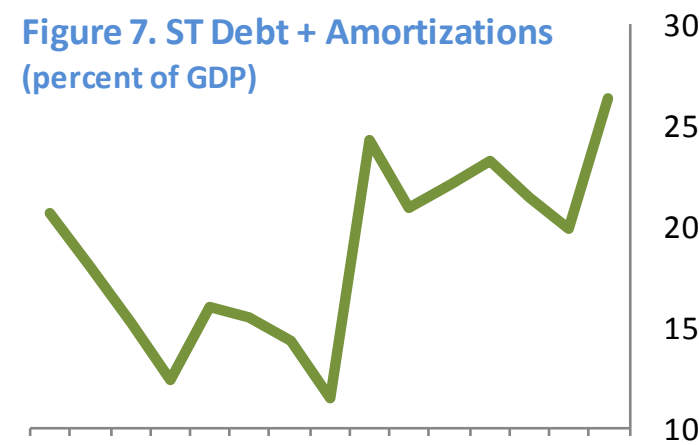

20012003200520072009201120132015

Source: BoB and staff estimates

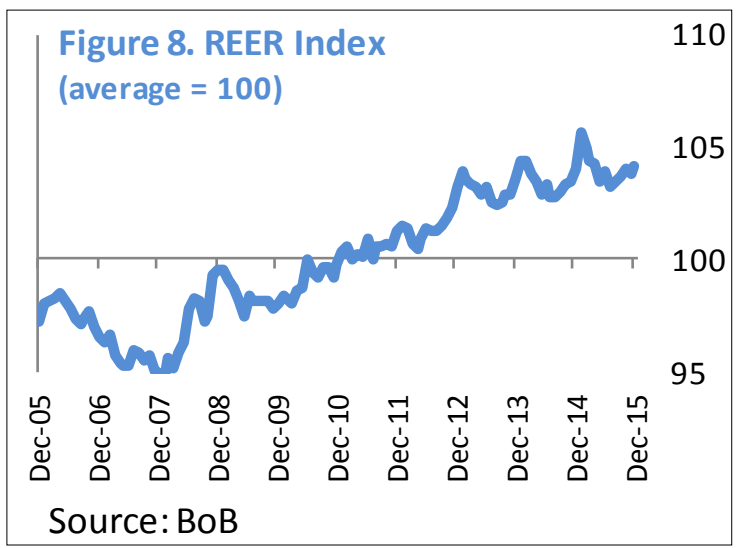


as inflation differentials have (ex-post) been marginally higher than expected ones. For 2016 the rate of crawl was changed from zero to 0.38 percent per annum. ${ }^{1}$

\section{B. Exchange Rate Assessment}

5. The assessment of Botswana's REER is based on the IMF's three alternative methodologies: two panel regression-based assessments, the CA and REER External Balance Assessment (EBA)-lite models, and a model-free analysis based on the sustainability of the net foreign asset position, the External Sustainability (ES) EBA-lite approach. EBA-lite is an extension of the EBA methodologies that use annual data for 146 countries for the 1995-2013 period, covering a broad group of countries, incorporating fundamentals for low and middle-income countries. ${ }^{2}$ It assumes that the CA and the REER are both endogenous variables that are simultaneously determined as a function of domestic and external variables including fundamentals, policy variables, cyclical conditions, and the global environment. ${ }^{3}$ As a result, the methodologies assess the CA and REER in a multilateral-consistent manner, as each country's variables are measured relative to a weighted-average of other countries' values. ${ }^{4}$

6. The regression-based methodologies provide no conclusive evidence that Botswana's REER is inconsistent with fundamentals. The CA gap is defined as the difference between the observed and fitted values of the CA EBA-lite regression model—which in turn corresponds to deviations of policy variables from their adequate levels and to regression residuals (the unexplained portion of the model). The gap is then converted into a REER misalignment using estimated trade elasticities. For Botswana, the CA gap is estimated to be 12.1 percent of GDP, as the fitted value of the regression is a CA deficit of 2.8 of GDP compared to an expected current account surplus of 9.3 percent in 2015 . The estimated elasticity of the trade balance to changes in the REER is -0.34 . Thus, according to the CA-EBA lite approach, the REER would need to appreciate by 35 percent for the CA surplus to be reduced to the fitted value of the regression. ${ }^{5}$ Alternatively, the use of the REER EBA-lite approach indicates that the REER would need to depreciate by just 0.5 percent to reach the fitted value of the regression.

7. Lastly, the external sustainability approach suggests that the REER would be slightly undervalued. This methodology is model-free but requires an assumption about the desired (optimal) level to stabilize the NFA position as a share of GDP. Since there is no optimality condition for this ratio, various policy scenarios (target values) are typically assumed. If the authorities wanted to stabilize the NFA at: (i) 47 percent of GDP (its 2014 level), the REER would need to appreciate by

\footnotetext{
${ }^{1}$ Historically, the rate of crawl had been negative (depreciation) in order to correct for inflation differentials with trading partners.

2 See further details of the EBA methodology in IMF (2013).

${ }^{3}$ Since the CA and ER are measured relative to other countries, they not only reflect a country's own characteristics, but also external conditions within a simultaneously determined general equilibrium system.

${ }^{4}$ This also implicitly recognizes that developments in a small economy would mostly influence its own CA and REER.

5 However, since almost all of Botswana's exports correspond to the sale of diamonds and copper in global markets (at international prices set in U.S. dollars), the CA EBA-lite methodology may overstate the misalignment as increases in export prices would appreciate the REER but also increase the CA surplus.
} 
18 percent; (ii) 90 percent of GDP (the average between 1994-2008), the REER would need to appreciate by 7 percent, and (iii) 110 percent of GDP (the highest historical value observed in 2001), the REER would need to appreciate by 2 percent. Naturally, all these projections crucially depend on the assumption for the evolution of diamond prices. For example, in a pessimistic world where real diamond prices remain at their currently depressed level during the projection period (due, for instance to a structural decline in demand), the NFA would stabilize at about 70 percent of GDP (the 2009 level) which suggests that the REER would currently be close to the equilibrium level and may need to depreciate somewhat to reach its 1994-2008 average. Therefore, the uncertainties about the evolution of diamond prices in coming years imply that the assessment of a possible misalignment of the REER should be taken with caution.

\section{References}

International Monetary Fund. (2013). "The External Balance Approach. 


\section{Appendix III. Debt Sustainability Analysis}

Botswana is a Market Access Country. During the period 2016-2021, public and publicly-guaranteed debt to GDP ratio is projected to be about 17 percent on average. As debt dynamics remain sustainable under the baseline and as standard stress tests show no debt vulnerability, Botswana remains classified as a low debt scrutiny country.

\section{A. Medium-Term Public Debt Sustainability}

1. Botswana's total public and publicly-guaranteed (PPG) debt has been broadly unchanged since 2014 at around 23 percent of GDP. The composition of the public debt has been moving away from external towards domestic owing to the gradual deepening of the local debt market, with the share of external debt in total debt falling from 74 percent at end-2013 to 71 percent at end-2014. Looking ahead, the PPG debt-to-GDP ratio is projected to fall from 25.2 percent of GDP in 2015 to about 12 percent of GDP by 2021.

2. Botswana's historically low level of public debt reflects the authorities' prudent management of the country's mineral wealth and sound macroeconomic policies. This resulted in a significant accumulation of reserves, which has served the country well in light of the volatility of export receipts and allowed for countercyclical policies when exports were depressed without much debt accumulation.

3. The baseline scenario underlying the staff's macroeconomic framework assumes a gradual recovery in export receipts and a supportive fiscal policy stance in 2015-17 to counteract the current weakness in mining exports. Over 2016-21, the primary fiscal balance is projected to be negative at around 0.3 percent of GDP, on average. The stock of gross PPG debt is projected to fall to about 12 percent of GDP by 2021 (Table 1 ).

In addition, Figure 1 shows two alternative scenarios:

i. The first scenario assumes that the main macro-variables are kept at their historical 10-year averages. In this case, the PPG debt-to-GDP ratio initially declines before rising to about 25 percent of GDP—higher than under the baseline. The main driver of this dynamic is the relatively better level of the primary balance as projected in the baseline compared to the historical average (which includes primary balances during the downturn of 2008-2011).

ii. The second scenario assumes no change in policies by holding the primary fiscal balance constant at its projected 2016 level of -3.6 of GDP) throughout the medium-term. In this case, public debt rises to about 40 percent of GDP, significantly higher than in the baseline.

4. As noted in Appendix $V$, if the country embarks on a program of higher public investment in the next decade, the amount of additional borrowing would still be modest and the public debt would remain sustainable. These conclusions rely on the country's abundant mineral resources (diamond reserves are expected to last until 2050) and the assumption of continued prudent macroeconomic policies and reforms. 


\section{B. Medium-Term External Debt Sustainability}

5. Botswana's gross external debt has also remained low. It fell from about 21 percent of GDP in 2012 to about 18 percent of GDP at end-2014 $4^{1}$ Public sector external borrowing was mainly from multilateral organizations, including the International Bank for Reconstruction and Development and the African Development Bank.

6. Looking ahead, the stock of external debt is projected to fall from an estimated 19 percent of GDP in 2015 to about 10 percent of GDP in 2021 (Table 2). A process of medium-term fiscal consolidation, supported by gradual improvement in international terms of trade and stable FDI inflows are expected to support further decline in Botswana's external debt ratios.

7. An alternative scenario with key debt-creating variables at their historical levels indicates that Botswana could be a net creditor vis-à-vis the rest of the world in just a few years time (Figure 2). This scenario would materialize if, other things equal, diamond prices recover towards their longterm average and other mining activities expand spurred by a recovery in world commodity prices (in contrast, the baseline projects a gradual recovery).

8. The staff simulations suggest that Botswana's external debt-to-GDP ratio is marginally sensitive only to a current account shock. A real depreciation shock, while it increases the debt-toGDP ratio initially, has only a marginal impact on the medium-term debt dynamics. Moreover, Botswana's external debt is not very sensitive to a shock in interest rates and economic activity.

9. In summary, Botswana's PPG is low and projected to remain subdued over the mediumterm. Debt dynamics remain sustainable under the baseline and standard stress tests show no debt vulnerability. As such, Botswana remains classified as a low debt scrutiny country.

\footnotetext{
${ }^{1}$ Including all publicly- guaranteed external debt.
} 
Table 1. Botswana: Public Sector Debt Sustainability Analysis (DSA) - Baseline Scenario

(in percent of GDP unless otherwise indicated)

Debt, Economic and Market Indicators ${ }^{1 /}$

Nominal gross public debt

Public gross financing needs

Actual

\begin{tabular}{|c|c|c|}
\hline \multicolumn{3}{|c|}{ Actual } \\
\hline $2005-2013$ & 2014 & 2015 \\
\hline 17.7 & 23.2 & 25.2 \\
\hline 0.5 & -1.9 & 5.2 \\
\hline
\end{tabular}

\begin{tabular}{rrrrrr}
\multicolumn{7}{c}{ Projections } \\
\hline 2016 & 2017 & 2018 & 2019 & 2020 & 2021 \\
\hline 22.2 & 19.7 & 17.4 & 15.3 & 13.4 & 12.1 \\
5.0 & 3.8 & 2.5 & 0.8 & 0.0 & -0.5
\end{tabular}

As of December 15, 2015

Sovereign Spreads

Spread (bp) $2 /$

CDS (bp)

Real GDP growth (in percent) Inflation (GDP deflator, in percent) Nominal GDP growth (in percent)

$\begin{array}{lcc}5.4 & 3.2 & -0.3 \\ 7.3 & 11.0 & -3.3 \\ 13.1 & 14.6 & -3.6 \\ 4.4 & 2.3 & 2.4\end{array}$

Effective interest rate (in percent) ${ }^{3 /}$

\begin{tabular}{rrrrrr}
3.7 & 4.6 & 4.7 & 5.0 & 4.8 & 4.1 \\
6.3 & 4.4 & 5.1 & 4.8 & 5.9 & 3.5 \\
10.2 & 9.2 & 10.0 & 10.0 & 11.0 & 7.7 \\
2.4 & 2.7 & 2.7 & 3.2 & 5.5 & 6.5 \\
\hline
\end{tabular}

$\begin{array}{llcc}\text { 4.1 } & \text { Ratings } & \text { Foreign } & \text { Local } \\ \text { 3.5 } & \text { Moody's } & \text { A2 } & \text { A2 } \\ 7.7 & \text { S\&Ps } & \text { A- } & \text { A- } \\ 6.5 & \text { Fitch } & \text { n.a. } & \text { n.a. }\end{array}$

Contribution to Changes in Public Debt

Actual Projections

\begin{tabular}{|c|c|c|c|c|c|c|c|c|c|c|c|}
\hline \multirow{3}{*}{ Change in gross public sector debt } & & \\
\hline & 2005-2013 & 2014 & 2015 & 2016 & 2017 & 2018 & 2019 & 2020 & 2021 & Cumulative & debt-stabilizing \\
\hline & 1.6 & -0.86 & 1.97 & -3.0 & -2.4 & -2.3 & -2.1 & -1.9 & -1.3 & & \\
\hline Identified debt-creating flows & -0.4 & -1.05 & 6.10 & -1.2 & -0.7 & -0.8 & -1.0 & -0.6 & -0.1 & -4.3 & balance $^{8 /}$ \\
\hline Primary deficit & -1.1 & -4.0 & 2.5 & 3.6 & 2.3 & 0.9 & -0.9 & -1.8 & -3.4 & 0.8 & 3.4 \\
\hline Primary (noninterst) revenue and grants & $5 \quad 39.9$ & 39.0 & 37.7 & 31.9 & 32.4 & 31.3 & 31.3 & 30.9 & 31.9 & 189.6 & \\
\hline Primary (noninterest) expenditure & 38.8 & 35.0 & 40.2 & 35.5 & 34.7 & 32.2 & 30.4 & 29.1 & 28.5 & 190.4 & \\
\hline Automatic debt dynamics ${ }^{4 /}$ & -0.5 & -1.1 & 5.9 & -1.6 & -1.0 & -0.9 & -0.8 & -0.5 & 0.2 & -4.6 & \\
\hline Interest rate/growth differential ${ }^{5 /}$ & -1.3 & -2.6 & 1.4 & -1.8 & -1.3 & -1.3 & -1.1 & -0.8 & -0.1 & -6.4 & \\
\hline Of which: real interest rate & -0.5 & -1.9 & 1.4 & -0.9 & -0.4 & -0.5 & -0.3 & -0.1 & 0.4 & -1.8 & \\
\hline Of which: real GDP growth & -0.8 & -0.7 & 0.1 & -0.8 & -0.9 & -0.8 & -0.8 & -0.7 & -0.5 & -4.6 & \\
\hline Exchange rate depreciation ${ }^{6 /}$ & 0.7 & 1.4 & 4.5 & $\ldots$ & $\ldots$ & $\ldots$ & $\ldots$ & $\ldots$ & $\ldots$ & $\ldots$ & \\
\hline Other identified debt-creating flows & 1.2 & 4.1 & -2.3 & -3.3 & -2.0 & -0.8 & 0.7 & 1.7 & 3.2 & -0.5 & \\
\hline Privatization receipts (negative) & 1.2 & 4.1 & -2.3 & -3.3 & -2.0 & -0.8 & 0.7 & 1.7 & 3.2 & -0.5 & \\
\hline Contingent liabilities & 0.0 & 0.0 & 0.0 & 0.0 & 0.0 & 0.0 & 0.0 & 0.0 & 0.0 & 0.0 & \\
\hline Other debt-creating flows (specify) & 0.0 & 0.0 & 0.0 & 0.0 & 0.0 & 0.0 & 0.0 & 0.0 & 0.0 & 0.0 & \\
\hline Residual, including asset changes" & 2.1 & 0.2 & -4.1 & -1.5 & -1.4 & -1.2 & -0.9 & -1.0 & -1.0 & -7.0 & \\
\hline
\end{tabular}

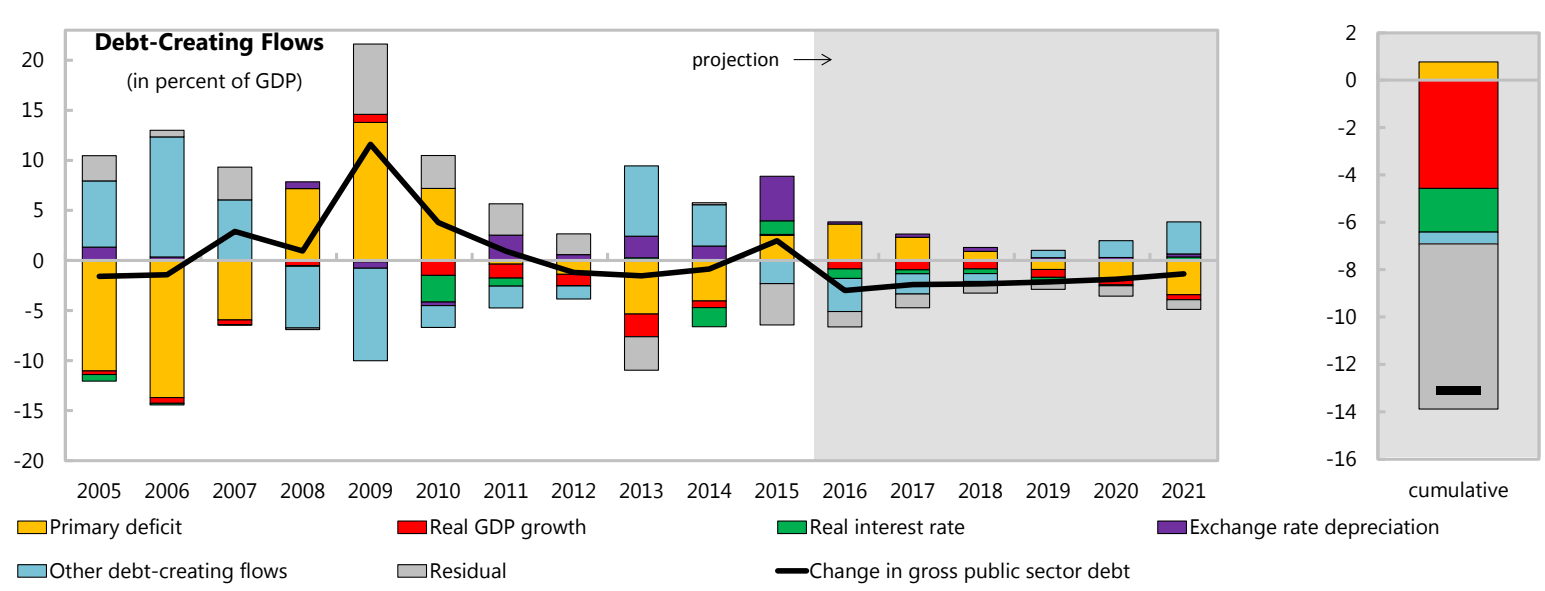

Source: IMF staff.

$1 /$ Public sector is defined as general government.

2/ Bond Spread over U.S. Bonds.

3/ Defined as interest payments divided by debt stock at the end of previous year.

4/ Derived as $[(r-p(1+g)-g+a e(1+r)] /(1+g+p+g p))$ times previous period debt ratio, with $r=$ interest rate; $p=$ growth rate of GDP deflator; $g=$ real GDP growth rate;

$\mathrm{a}=$ share of foreign-currency denominated debt; and $\mathrm{e}=$ nominal exchange rate depreciation (measured by increase in local currency value of U.S. dollar).

5 / The real interest rate contribution is derived from the denominator in footnote 4 as $r-\pi(1+g)$ and the real growth contribution as $-g$.

6 / The exchange rate contribution is derived from the numerator in footnote $2 /$ as ae $(1+r)$.

7/ For projections, this line includes exchange rate changes during the projection period.

8/ Assumes that key variables (real GDP growth, real interest rate, and other identified debt-creating flows) remain at the level of the last projection year 
Figure 1. Botswana: Public DSA - Composition of Public Debt and Alternative Scenarios Composition of Public Debt

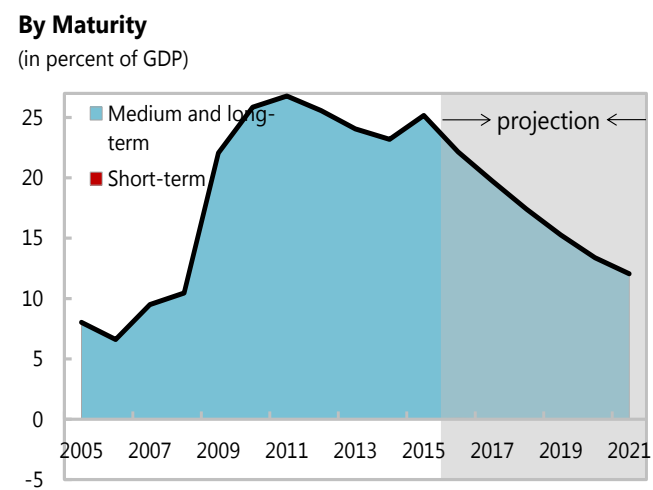

\section{By Currency}

(in percent of GDP)

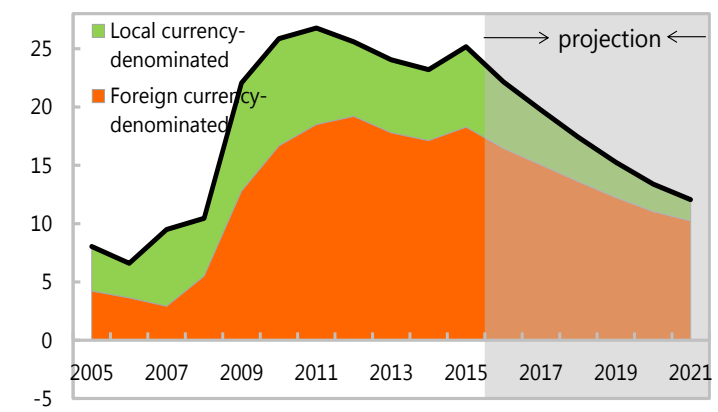

\section{Alternative Scenarios}

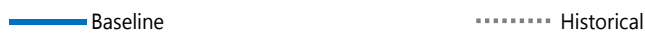

$-=-$ Constant Primary Balance

\section{Gross Nominal Public Debt}

(in percent of GDP)

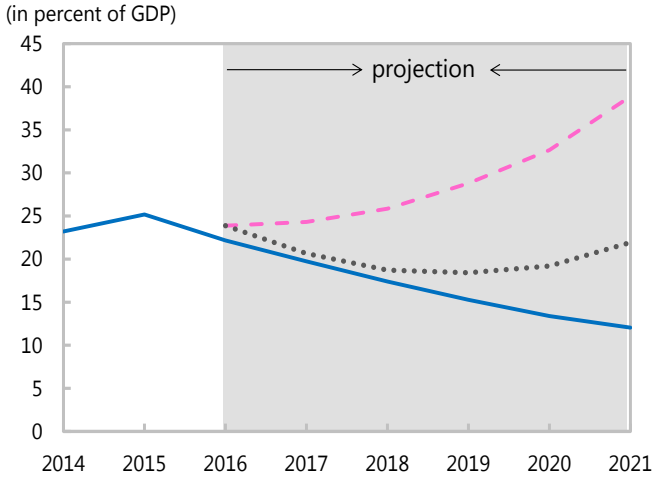

Public Gross Financing Needs

(in percent of GDP)

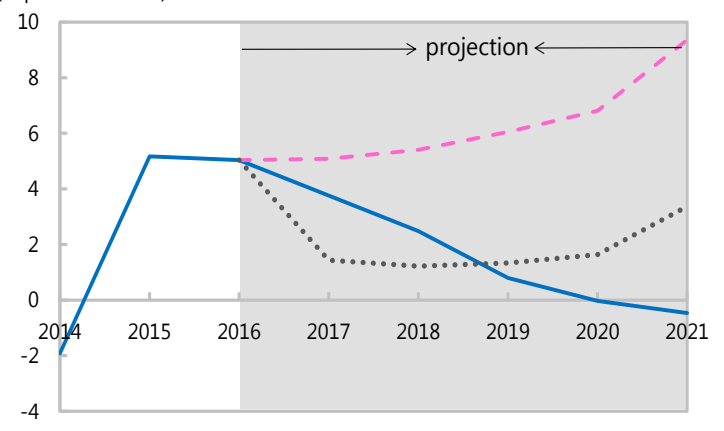

Underlying Assumptions

(in percent)

\begin{tabular}{lcccccc} 
Baseline Scenario & 2016 & 2017 & 2018 & 2019 & 2020 & 2021 \\
\cline { 2 - 7 }$\quad$ Real GDP growth & 3.7 & 4.6 & 4.7 & 5.0 & 4.8 & 4.1 \\
Inflation & 6.3 & 4.4 & 5.1 & 4.8 & 5.9 & 3.5 \\
$\quad$ Primary Balance & -3.6 & -2.3 & -0.9 & 0.9 & 1.8 & 3.4 \\
$\quad$ Effective interest rate & 2.4 & 2.7 & 2.7 & 3.2 & 5.5 & 6.5 \\
Constant Primary Balance Scenario & & & & & \\
$\quad$ Real GDP growth & 3.7 & 4.6 & 4.7 & 5.0 & 4.8 & 4.1 \\
Inflation & 6.3 & 4.4 & 5.1 & 4.8 & 5.9 & 3.5 \\
Primary Balance & -3.6 & -3.6 & -3.6 & -3.6 & -3.6 & -3.6 \\
Effective interest rate & 2.4 & 2.5 & 2.5 & 2.9 & 4.4 & 4.8 \\
& & & & & & \\
& & & & & & \\
\hline
\end{tabular}

Histocial Scenario

Real GDP growth

Inflation

Primary Balance

Effective interest rate

\begin{tabular}{cccccc}
\hline 2016 & 2017 & 2018 & 2019 & 2020 & 2021 \\
\hline 3.7 & 4.7 & 4.7 & 4.7 & 4.7 & 4.7 \\
6.3 & 4.4 & 5.1 & 4.8 & 5.9 & 3.5 \\
-3.6 & 0.0 & 0.0 & 0.0 & 0.0 & 0.0 \\
2.4 & 2.5 & 2.1 & 2.2 & 4.0 & 4.4
\end{tabular}

Source: IMF staff. 


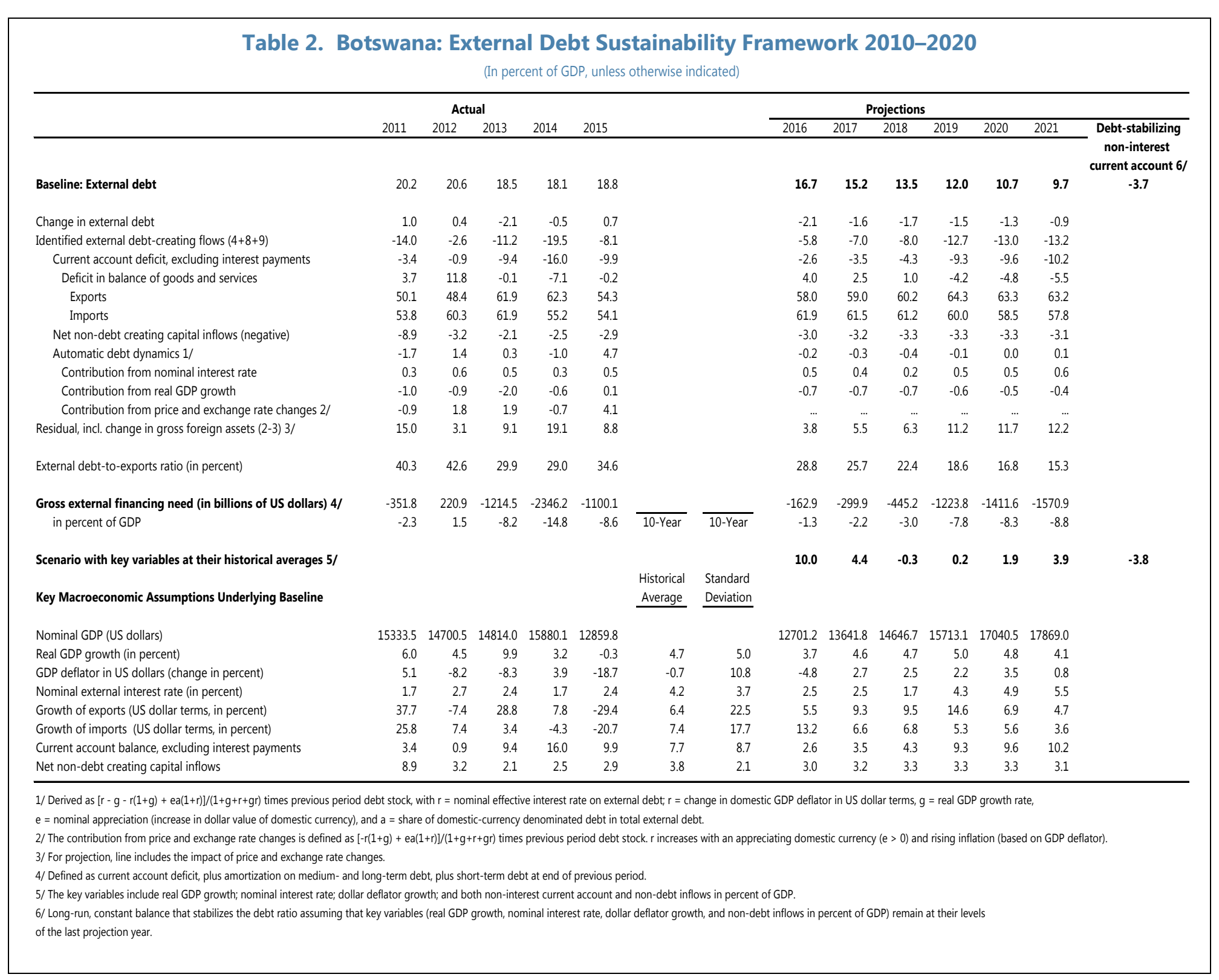


Figure 2. Botswana: External Debt Sustainability: Bound Tests 1/2/

(External debt in percent of GDP)

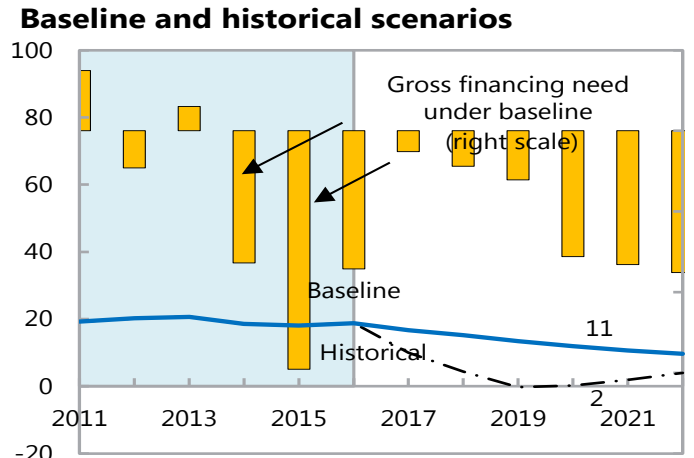

\section{Growth shock}

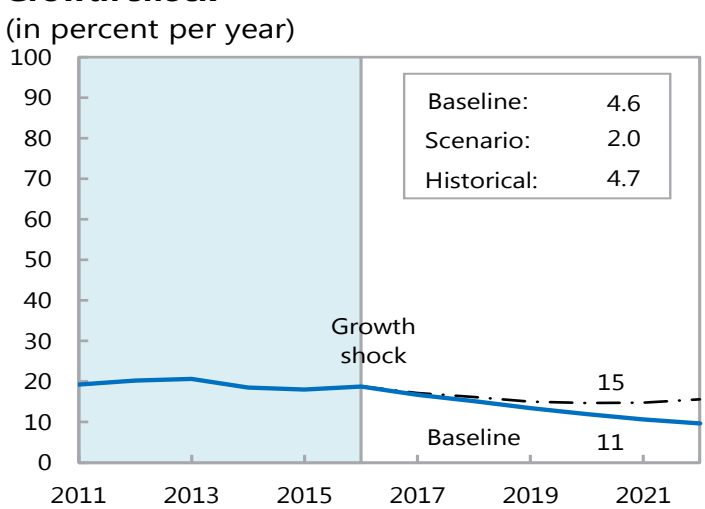

\section{Combined shock 3/}

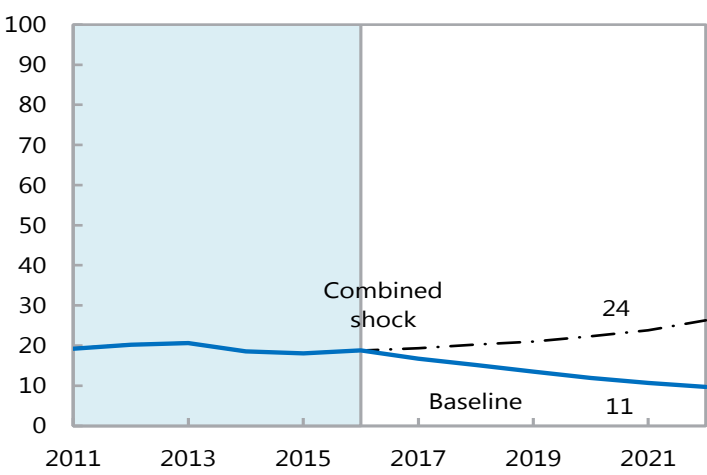

Interest rate shock (in percent)

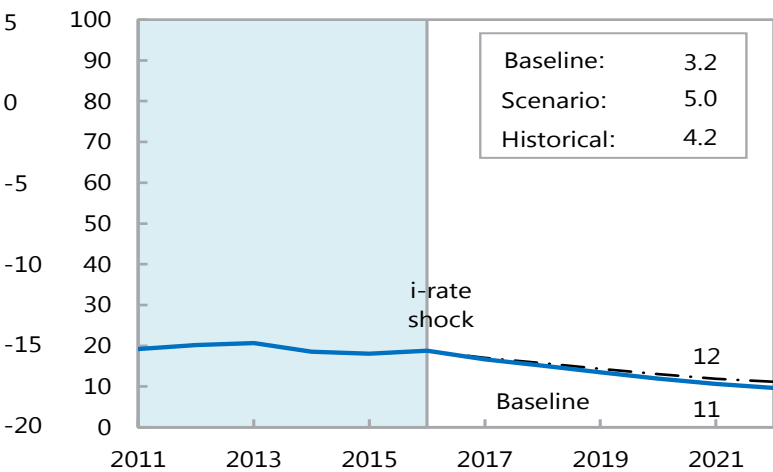

Non-interest current account shock

(in percent of GDP)

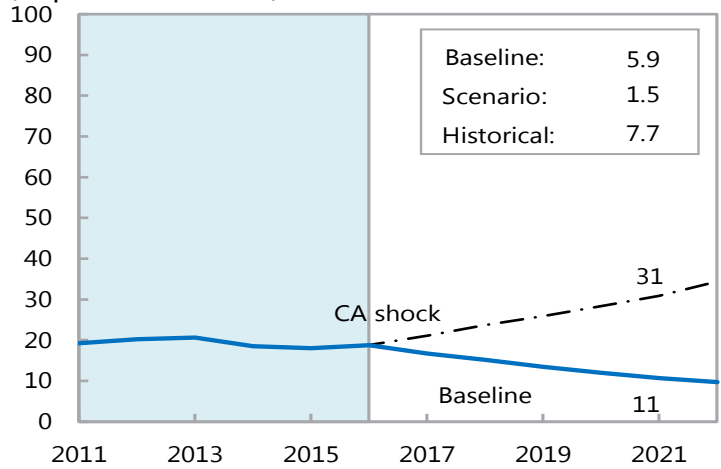

Real depreciation shock 4/

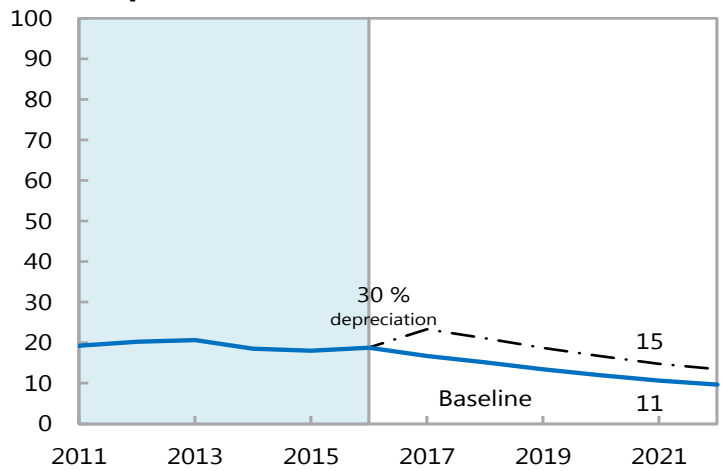

Sources: International Monetary Fund, Country desk data, and staff estimates.

1/ Shaded areas represent actual data. Individual shocks are permanent one-half standard deviation shocks. Figures in the boxes represent average projections for the respective variables in the baseline and scenario beir presented. Ten-year historical average for the variable is also shown.

2/ For historical scenarios, the historical averages are calculated over the ten-year period, and the information used to project debt dynamics five years ahead.

$3 /$ Permanent $1 / 4$ standard deviation shocks applied to real interest rate, growth rate, and current account

4/ One-time real depreciation of 30 percent occurs in 2010. 


\section{Appendix IV. Fiscal Rules for Botswana}

Botswana existing fiscal framework consists of guiding principles in the form of expenditure ceilings and formal debt limits on domestic and external debt. Although the framework has served the country relatively well, the authorities could consider strengthening it by adopting a new fiscal rule with clear links between the budget, Pula Fund deposits and withdrawals, and a medium-term investment program.

\section{A. Background}

1. A fiscal rule can be defined as a permanent constraint on fiscal policy through simple, credible, and reasonably flexible numerical limits on budgetary aggregates ${ }^{1}$ The role of a fiscal rule is to support fiscal credibility and discipline. Fiscal rules include budget balance rules, debt rules, expenditure rules and revenue rules, each with different implications for fiscal policy response to shocks. $^{2}$

2. For resource-rich countries, fiscal rules aim at managing volatility and exhaustibility of natural resources in addition to supporting fiscal credibility and discipline. Rules should therefore encompass three inter-related objectives: (i) appropriately assess the macro-fiscal stance; (ii) ensure long-term sustainability and intergenerational equity, and (iii) provide instruments to help manage revenue volatility and uncertainty. The relative importance of these objectives depends on countryspecific circumstances and may change over time.

3. Fiscal rules have pros and cons irrespective of a country's capital scarcity and exhaustibility. One key advantage of fiscal rules is that they could potentially correct the distorted incentives in policymaking. These distortions may be driven by governments' shortsightedness and the "common pool" problem, which result in deficit bias. ${ }^{3}$ Concerns regarding rule-based fiscal policy abound. First, rules may be redundant in that if they are adopted without sufficient political commitment to pursue a disciplined policy they are unlikely to be sustained, which may ultimately undermine policy credibility. Second, some rules may not be binding in good times and may even entail a procyclical stance in bad times as they constrain discretion. Third, rules are generally silent on the composition of the eventual fiscal adjustment needed for compliance and may therefore reduce the quality of fiscal policy, resulting in easy-to-cut capital spending that may have high social returns with potential negative impact on long-term growth prospects. ${ }^{4}$ Rules may also distract from other

\footnotetext{
${ }^{1}$ See Kopits and Symansky, 1998.

${ }^{2}$ As described in Budina and others, 2012a, overall balance or debt rules typically provide the lowest degree of cyclical flexibility with regard to output shocks while cyclically adjusted or structural balance rules allow the full operation of automatic stabilizers, though they do not provide room for discretionary fiscal stimulus. As regards to expenditure rules, they are consistent with cyclical and discretionary reductions in tax revenues, but they do not normally permit discretionary expenditure stimulus. Finally, revenue rules do not generally account for the operation of automatic stabilizers on the revenue side in a downturn.

${ }^{3}$ Shortsightedness is when governments exhibit insufficient attention to longer-term requirements when faced with electoral prospects or opportunistically raise spending or cut taxes to increase reelection chances (See Rogoff, 1990). The common pool problem occurs when special interest groups or constituencies fail to internalize the overall budgetary impact of their competing demands (See Debrun and Kumar, 2007).

${ }^{4}$ See Blanchard and Giavazzi, 2004.
} 
priorities as adjusting to a deficit limit may require difficult measures, thus diverting political capital from other priorities. Fourth, in an environment of fiscal pressure, rules can encourage "creative" accounting and off-budget operations to be seen abiding by the rule. Experiences with fiscal rules show mixed results. In some countries, for example Chile and Norway, a fiscal path was established and adhered to, while in other countries (Venezuela, several European Union members) fiscal rules were ignored, distorted, or dismantled.

\section{B. Current Fiscal Framework in Botswana}

4. Botswana has one existing binding debt limit and two guiding principles that were embedded in past National Development Plans: (i) a debt limit legislated as the Stock, Bonds, and Treasury Bills Act of 2005 that caps total domestic and foreign debt each to 20 percent of GDP, ${ }^{5}$ and (ii) spending limits on total government spending and balanced budget in cash terms over the NDP planning period. The expenditure limits include a 40 percent of GDP government spending cap introduced in 2006 (NDP9), and a target reduction of government spending to 30 percent of GDP by the end of the financial year 2015/16 (NDP10). In capping government spending, the authorities aimed at reducing the vulnerability of the budget to fluctuations in mining revenues. The 40 percent limit has not been breached except during the 2008 financial crisis when overall spending increased to about 47 and 50 percent of GDP in 2008/09 and 2009/10, respectively, in light of the recession that Botswana experienced during that period. Excluding the debt ceilings, the aforementioned rules are objectives rather than institutionalized binding constraints. With the exception of the legislated debt ceilings, the ad hoc nature and inconsistent use of the above rules point to weaknesses in the current framework that could be addressed in the context of NDP 11 .

\section{Strengthening Botswana's Fiscal Framework}

\section{Rationale}

5. While the existing framework has generally been helpful, a simpler fiscal rule could better shield government spending from pro-cyclicality, ensure fiscal sustainability, and preserve Botswana's wealth for future generations. The authorities' fiscal policy has traditionally focused on the need to balance the overall budget, but the overall fiscal balance may not be a reliable indicator of the government's adjustment effort. The guiding principles also give rise to unintended procyclicality in spending, since when the price of diamonds increases, GDP also increases thus allowing for an increase in spending (Figure 1 shows a positive correlation between current expenditure and mineral revenue over the period 1994/95-2014/15).

\footnotetext{
${ }^{5}$ This debt rule has been observed as Botswana domestic and external debt has each been lower than 20 percent of GDP.
} 


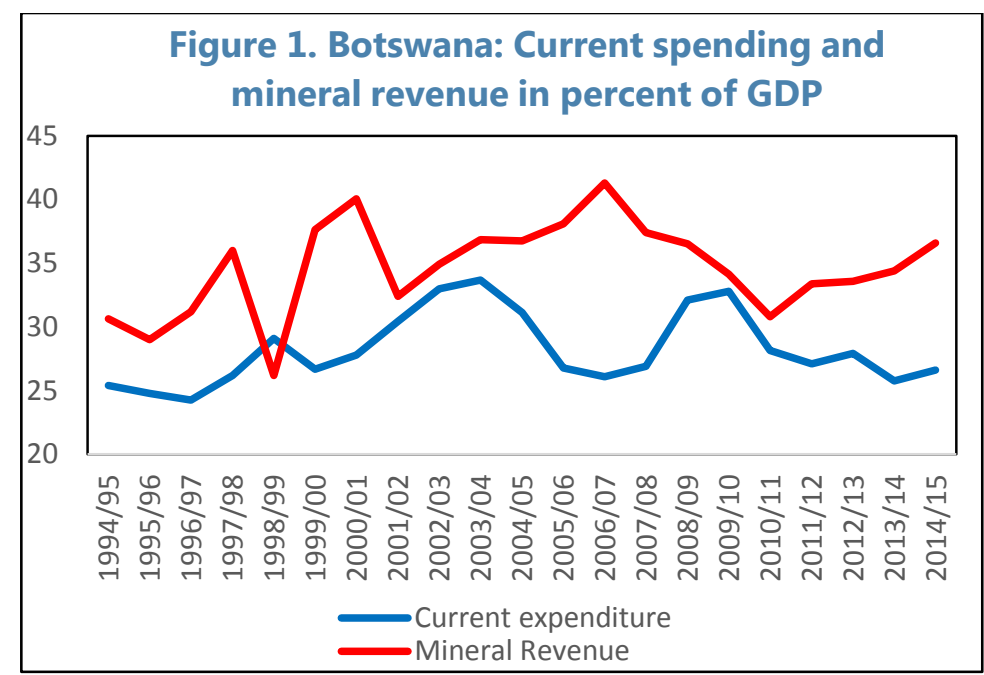

\section{Options}

6. Fiscal rules in resource-rich countries vary in scope and objective:

i. Timor-Leste's non-mineral primary balance (NMPB) rule. The rule helps limit expenditures and/or increase non-mineral revenues and reduce dependence on exhaustible natural resource revenues. The rule can include an escape clause to account for cases of crises cases when a deficit target may be exceeded.

ii. Norway's Non-Mineral Deficit rule, which limits the size of the non-mineral deficit to an assumed rate of return on the accumulated assets (Pula Fund). ${ }^{6}$ The disadvantage of this rule is that Botswana has large development needs.

iii. Chile's structural primary balance rule, which has mechanisms for price smoothing and cyclical adjustments. This rule will require experts to determine how diamonds prices will perform over the long run and advise expenditure limits based on a long-term price. The rule could be administratively burdensome and future diamond demand would need to be forecast, which is very difficult.

\section{Possible Fiscal Rule for Botswana}

7. A non-mineral primary balance (NMPB) rule in percent of non-mineral GDP could be an option. The objective of the NMPB is to gradually adjust spending to the level of non-mineral revenues and to eventually achieve enough non-mineral revenue to cover both current and capital expenditure (given diamond exhaustibility). Another option could be a non-mineral primary current balance, but this option will require strong complementary safeguards to prevent accounting changes. In fact, this rule appears to be inferior on account of existing weaknesses in Botswana's chart of accounts that do not allow for the proper classification of current versus capital expenditures. Any of these options would need to be complemented with a clear link between the

\footnotetext{
${ }^{6}$ For example, non-mineral deficit $=$ non-mineral revenues $+(4 \%$ * value of the Pula Fund $)$. Effectively this would mean non-mineral revenue will be used to cover expenditure, while the rest of the revenue from minerals is saved in the natural resource fund for the future.
} 
budget process, deposits and withdrawals from the Pula Fund, and the medium-term fiscal framework.

8. The NMPB could facilitate non-mining revenue mobilization, restrain spending, and ensure fiscal sustainability. Notably, non-mineral (or non-resource) revenue in Botswana is far below comparable levels in countries with similar income per capita. For instance, upper middle-income countries like South Africa and Turkey have non-resource tax revenues near 30 percent of GDP (Figure 2). A bold tax reform program in the context of a successful diversification and growth strategy could help over time unleash Botswana's large non-mining revenue potential which will be critical to finance future current and capital expenditures.

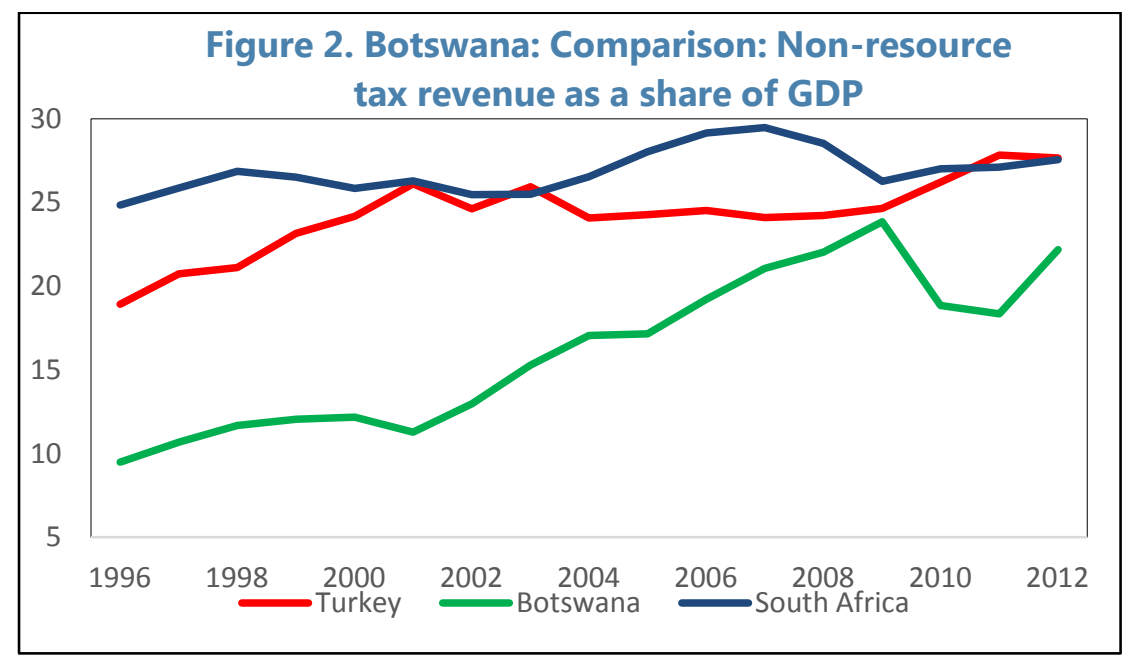

9. $\quad$ Although there is a need for a clear and effective fiscal rule and the NMPB may be well suited for Botswana, further analysis is warranted. Any rule should take a long-term view of revenues, especially mineral revenues, which are likely to decline in coming decades (diamond reserves could last up to 2050). ${ }^{7}$ Also, they should limit expenditure growth, especially on current outlays, denominating them as a share of non-mineral GDP to avoid ramping up expenditure during mineral revenue booms. Lastly, given the importance of scaling-up public investment and the lack of development of public investment management institutions, there will be a simultaneous need for (i) improving the planning, allocating, executing and monitoring of public investment projects; (ii) formulating a clearly prioritized public investment program, and (iii) linking that program to the medium-term fiscal framework.

\footnotetext{
${ }^{7}$ The key characteristics of a clear and credible fiscal rule are (i) simplicity; (ii) sustainability, by focusing on ensuring medium-term fiscal health; (iii) preventing pro-cyclicality); (iv) flexibility, by including well-defined escape clause and by limiting excessive ad hoc changes.
} 


\section{References}

Blanchard, Olivier J. and F. Giavazzi, (2004), "Improving the SGP Through a Proper Accounting of Public Investment," CEPR Discussion Paper No. 4220.

Budina, N., T. Kinda, A. Schaechter, and A. Weber, 2012b, "Fiscal Rules at a Glance: Country Details from a New Dataset," IMF Working Paper 12/273 (Washington: International Monetary Fund).

Debrun, X., L. Moulin, A. Turrini, J. Ayuso-i-Casals and M. S. Kumar (2008), "Tied to the Mast? National Fiscal Rules in the European Union," Economic Policy, April 2008, pp. 299-362.

Debrun, X. and M. S. Kumar (2007), "The Discipline-Enhancing Role of Fiscal Institutions: Theory and Empirical Evidence," IMF Working Paper 07/171.

International Monetary Fund (IMF). 2012a. "Macroeconomic Policy Frameworks for Resource-Rich Developing Countries." Washington. http://www.imf.org/external/np/pp/eng/2012/082412.pdf. 2012b. "Fiscal Regime for Extractive Industries: Design and Implementation." IMF Policy Paper. Washington. http://www.imf.org/external/np/pp/eng/2012/081512.pdf.

_. 2014a. "Sovereign Asset-Liability Management Guidance for Resource-Rich Economies." IMF Policy Paper. Washington. http://www.imf.org/external/np/pp/eng/2014/061014.pdf.

_ 2014b. "Spillovers in International Corporate Taxation." IMF Policy Paper. Washington. https://www.imf.org/external/np/pp/eng/2014/050914.pdf.

Kopits, G. and S. Symansky (1998), Fiscal Rules, IMF Occasional Paper 162. 


\section{.Appendix V. Scaling Up Public Investment: Simulations with the DIGNAR Model}

A gradual scaling-up of public investment, together with complementary structural reforms, yields higher growth in the non-mineral sector and higher private consumption over the long-run. The scaling up can be financed primarily with mining revenues, but reforms to simultaneously improve the business environment, increase the efficiency of public spending (and investment in particular), and mobilize domestic revenues, will be essential.

1. Botswana has experienced strong economic growth and impressive progress with poverty reduction over the past two decades, the result of prudent policies, a good institutional set up, and a buoyant diamond industry. Looking ahead, however, challenges remain, namely high levels of inequality and unemployment, insufficient infrastructure (particularly water supply and power generation), and lack of economic diversification. The mining wealth, especially diamonds, is expected to last until 2050, and could provide the basis for tackling these challenges and allow the country to avoid the so called "middle-income trap".

2. The forthcoming National Development Plan should be centered on a well-thought approach to build physical and human capital. A well-developed infrastructure appropriately tailored to the development of selected sectors (e.g. tourism) and a better skilled workforce would, combined with reforms to improve the business environment, have a better chance to boost competitiveness, facilitate diversification, and generate employment.

3. The economic impact of scaling up of investment will primarily depend on the quality and efficiency of public investment. Empirical studies suggest that inefficiencies in public investment (due to poor planning, weak management practices, lack of complementary infrastructure, etc) are high in developing countries-on average only about half of public investment expenditure translates into effective investment (i.e. investment that enhances the public capital stock). Botswana is not an exception, considering the under execution of the investment budget in recent years, capacity constraints, and reported inefficiencies. Notably, the quality of project design and management also affects the quality and effectiveness of public capital, the return on investment, and ultimately the rate of economic growth ${ }^{1,2}$

\footnotetext{
${ }^{1}$ Complementarities between public and private capital in production imply that the return to private investment is also affected by the efficiency and productivity of public investment.

${ }^{2}$ Low efficiency and quality of public investment are a concern for Botswana, as expressed in the World Bank's Systematic Country Diagnostic (March 2015) but also in the Botswana Mid-Term Review of NDP10. The degree of public investment efficiency is estimated to be close to 60 percent (see Dabla-Norris et al. (2011)).
} 
4. To assess the implications of an investment scale-up, staff applied the DIGNAR (Debt, Investment, Growth and Natural Resources) model calibrated to reflect features of Botswana. ${ }^{3}$ DIGNAR is a dynamic macroeconomic framework for analyzing the effects of public investment scale-ups on economic growth and debt sustainability in resource rich economies. The framework captures key characteristics of developing countries, including investment inefficiencies and absorptive capacity constraints. The model was extended to account for foreign direct investment and the positive effects it has on the domestic economy, through transfer of technology and knowhow as well as complementary reforms that improve the overall business environment. ${ }^{4}$

5. Initially, two alternative approaches to public investment scaling-up were considered, neither of which assume major efforts to increase investment efficiency:

a. A gradual scaling-up approach, where spending on growth-enhancing investment projects in infrastructure is increased gradually (up to 12 percent of GDP over the short- to medium-run). This approach allows for higher long-term growth in non-mineral output of about 0.5 percent above trend and increased private investment and consumption levels (Figure 1). The higher government financing needs, associated with the increase in investment, are accommodated by using a portion of existing Pula Fund reserves up to a notional floor set at 50 percent of the current stock (assumed to be saved to generate income flows for future generations), together with rationalized government spending, successful revenue mobilization efforts, and a modest amount of domestic borrowing.

b. A more aggressive, front-loaded scaling-up approach sees public investment increase faster and by more relative to the gradual approach (reaching about 14 percent of GDP in the short run). ${ }^{5}$ However, this approach delivers only a slightly larger build-up of public capital and higher nonmineral output but lower private consumption and welfare in the medium-run compared to the gradual case (Figure 1). This is primarily because the faster process collides with absorptive capacity constraints which lower the degree of investment efficiency and increase the cost of public capital build-up. The aggressive scaling-up also implies a slightly larger build-up of public debt, which carries a cost in terms of servicing the accumulated debt.

\footnotetext{
${ }^{3}$ For technical details on DIGNAR, see Melina G., S. Yang, and L.F. Zanna (2014): Debt Sustainability, Public Investment, and Natural Resources in Developing Countries: the DIGNAR model, IMF Working Paper No. 14/50.

${ }^{4}$ A recent study by Lederman G., T. Mengistae and L. C. Xu (2010): 'Macroeconomic Consequences and Macroeconomic Causes of Foreign Direct Investment in Southern African Countries', World Bank Working Paper No. 5416, finds evidence of such positive effects. It also finds that the quality of infrastructure and the level of economic growth are among the main determinants of FDI inflows in Southern African Countries.

${ }^{5}$ These levels are well within the range of past values for Botswana and consistent with the country's infrastructure deficit, where in selected years public investment rose to over 15 percent of GDP.
} 
Figure 1. Botswana: Effects of Alternative Public Investment Scaling-Ups
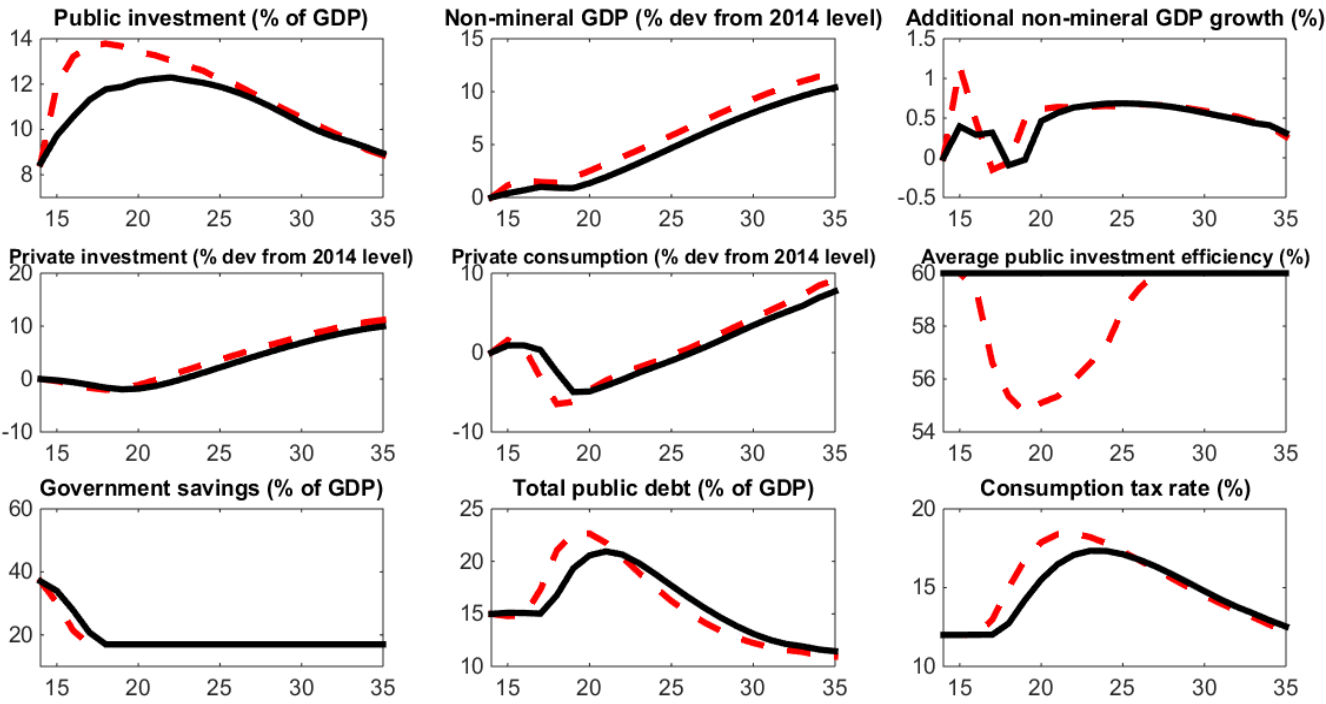

Gradual $\quad-\quad-$ Aggressive

Source: IMF staff simulations.

7. Better project design, selection and implementation can significantly improve the quality of public infrastructure and the average real return on investment. Figure 2 provides an illustrative example, considering an increase in public investment efficiency from 60 to 80 percent over a period of ten years, together with an increase in the annual net return on investment from 15 to 20 percent, a range of values reflecting the existing empirical evidence. ${ }^{1}$ Under this superior scenario, the gradual scaling up of investment in infrastructure leads, on average, to additional long-run growth of about 1.2 percentage points of non-mineral GDP per year.

8. The improved efficiency and productivity of public investment allows for a larger build-up of productive public capital which raises the return to private investment, both domestic and foreign, and enhances the positive spill-over effects of the latter. Private investment and consumption are in this case significantly higher. Over time, as the growth effects of the additional investment take hold, savings in the Pula Fund quickly recover and continue to accumulate over time. ${ }^{2}$

\footnotetext{
${ }^{6}$ A degree of public investment efficiency of around 80 percent corresponds to the levels of efficiency found in higher income countries (see IMF Policy Paper 'Improving Public Investment Efficiency in the G-20', Sep. 2015).

${ }^{7}$ Using a portion of the accumulated foreign exchange reserves to support the scaling up of investment improves macroeconomic outcomes, as it reduces the extent of government borrowing and debt service needs.
} 
Figure 2. Botswana: Effects of Improved Efficiency and Productivity of Public Investment
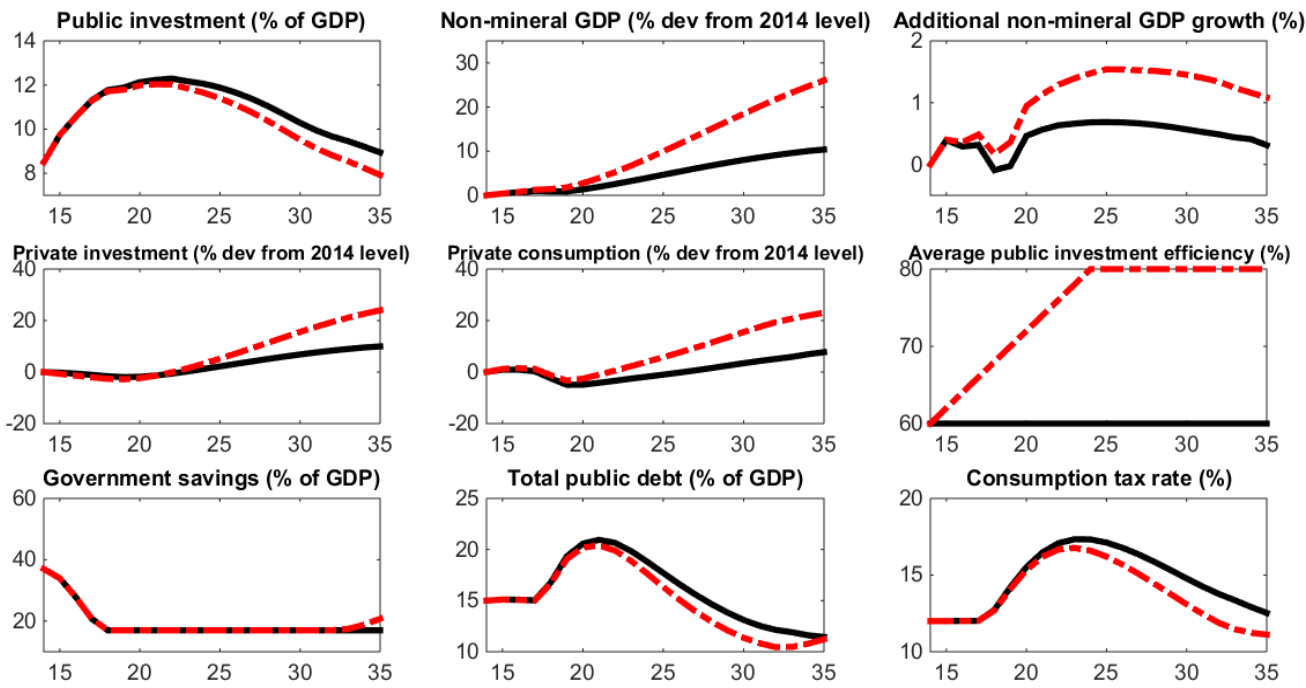

\footnotetext{
Scaling-up scenario (Efficiency 60\%, Return to public investment 15\%)

- With improved efficiency and productivity (Efficiency $80 \%$, Return to public investment 20\%)
}

Source: IMF staff simulations.

9. In sum, Botswana could undertake a gradual scaling up of public investment over the next 510 years financed mostly with accumulated and prospective mineral receipts and, over time, domestic revenues. The results will depend on the extent to which the authorities can strengthen the capacity to manage these investments within well-designed priority infrastructure projects, including by preparing a prioritized public investment program based on sound cost-benefit analysis and boosting education and training of the labor force, as well as embarking on selective private-public partnerships and much-needed complementary reforms to reduce red tape and regulations to enable the growth of the private sector. Such conversion of mineral wealth into productive and high quality public capital will, in turn, help diversify the economy and foster sustained and inclusive growth. Lastly, domestic revenue mobilization will also be important to support the budget over time, notably in light of the exhaustibility of mineral receipts 


\section{INTERNATIONAL MONETARY FUND}

\section{BOTSWANA}

STAFF REPORT FOR THE 2015 ARTICLE IV

March 1, 2016

CONSULTATION-INFORMATIONAL ANNEX

Prepared By

African Department in Consultation with the Statistics

Department and World Bank Staff

\section{CONTENTS}

FUND RELATIONS $\underline{2}$

JOINT WORLD BANK AND IMF WORK PROGRAM $\underline{4}$ 


\section{FUND RELATIONS}

(As of February 9, 2016)

\section{Membership Status}

Joined July 24, 1968; Article VIII

General resources account

Quota

Fund holdings of currency

Reserve position in Fund

SDR Department

Net cumulative allocation

Holdings
$\underline{\mathrm{SDR} \text { (million) }}$

87.80

60.53

27.28

$\underline{\mathrm{SDR} \text { (million) }}$

57.43

85.70

\begin{tabular}{r} 
Percent of Quota \\
100.00 \\
68.94 \\
31.07 \\
\\
Percent of Quota \\
\hline 100.00 \\
149.21
\end{tabular}

Outstanding Purchases and Loans

None

Financial Arrangements

None

Project Obligations to Fund

None

Implementation of HIPC Initiative

Not Applicable

Implementation of Multilateral Debt Relief Initiative

Not Applicable

Implementation of Catastrophe Containment and Relief

\section{Exchange Rate Arrangements}

The exchange rate of the Botswana pula is a crawling peg arrangement against a basket of currencies. As of February 4, 2016, the exchange rate of the U.S. dollar to the pula was US\$1= $\mathrm{P} 11.28$, and that of the South African rand to the pula was $\mathrm{R} 1=\mathrm{P} 0.71$.

Botswana accepted the obligations of Article VIII, Sections 2, 3, and 4 of the Fund's Articles of Agreement, as of November 17, 1995, and maintains an exchange rate system free of restrictions in the making of transfers and payments of current account transactions.

\section{Article IV consultation}

Botswana is on a standard 12-month consultation cycle. The last Article IV consultation was concluded by the Executive Board on July 3, 2014 on a lapse of time basis. 


\section{Technical assistance}

\section{Department Dates}

FAD

LEG

STA

MCM

2014
May 2013-May 2014

January 2014

February-March 2014

August 2014

August 2014

November-December

December 2014

February 2015

March 2015

March-April 2015

May-June 2015

May-June 2015

June 2015

July 2015

July-August 2015

October 2015

October 2015

February 2016

May 2014

January 2015

June 2015

June-July 2015

August 2015

November 2015

January 2016

October 2014

February-March 2015

April 2015

June 2015

July-August 2015

September 2015

October 2015

March 2016

\section{Purpose}

Macro-fiscal Advisor

$\mathrm{CU}$ regional harmonisation and trade facilitation

Organization structure to enhance efficiency of tax administration Property Tax

Medium-Term Expenditure Framework and EU project review

IPSAS Accrual Accounting and Reporting

Customs Administration

Review the Domestic Tax business processes, Tax Administration

Customs Administration

Medium-Term Expenditure Framework

Cash Management

Public Asset Management Policy Framework

Medium-Term Expenditure Framework

Tax Administration

Accrual accounting and reporting

Customs Administration

Medium-Term Expenditure Framework

Fiscal Law

AfDB Open Data Initiative for Data Submission

National Accounts Statistics

GDDS/NSDP Development

National Accounts

Government Finance Statistics

e-GDDS Implementation

Price Statistics

Multi-Topic TA Needs Assessment Mission

Non-Bank Deposit Taking Institutions Regulation and Supervision Macro Economic Modeling

Payments and Settlement System - Overnight and Regulation

Non-Bank Deposit Taking Institutions Regulation and Supervision Macro Economic Modeling

Payments and Settlement System - Overnight and Regulation

Macro Economic Modeling 


\section{JOINT WORLD BANK AND IMF WORK PROGRAM}

(As of February 9, 2016)

\begin{tabular}{|c|c|c|c|}
\hline Title & Products & $\begin{array}{l}\text { IBRD \$ } \\
\text { Million }\end{array}$ & $\begin{array}{l}\text { Provisional } \\
\text { Timing of } \\
\text { Missions }\end{array}$ \\
\hline \multicolumn{4}{|c|}{ A. Mutual Information on Relevant Work Programs } \\
\hline \multirow{3}{*}{$\begin{array}{l}\text { World Bank } \\
\text { indicative work } \\
\text { program in the } \\
\text { next } 12 \text { months }\end{array}$} & $\begin{array}{l}\text { Current Lending } \\
\qquad \quad \text { Integrated Transport Project }\end{array}$ & 186 & January 31, 2020 \\
\hline & $\begin{array}{l}\text { Proposed Lending } \\
\text { - Water Security \& Efficiency } \\
\text { - } \quad \text { Social Protection Modernization } \\
\text { - Transforming Senior Secondary } \\
\text { - } \text { Education } \\
\text { Health Systems Support }\end{array}$ & $\begin{array}{c}150 \\
30 \\
50 \\
40\end{array}$ & $\begin{array}{l}\text { FY16-17 } \\
\text { FY17-18 } \\
\text { FY17-19 } \\
\text { FY18 }\end{array}$ \\
\hline & $\begin{array}{l}\text { Analytical and Advisory Assistance (ongoing) } \\
\text { - } \quad \text { Economic Diversification RAS } \\
\text { - } \quad \text { Programmatic Fiscal } \\
\text { - } \quad \text { Mobile Banking and Financial Inclusion } \\
\text { - } \quad \text { Regional Demographic Study } \\
\text { - } \quad \text { Regional Water-Energy Nexus Study } \\
\text { - } \quad \text { Lesotho Highlands-Botswana Water } \\
\text { - } \quad \text { Heansfer Study (Grant) } \\
\text { - } \quad \text { Ren financed) } \\
\text { - } \quad \text { Botswana Tradide Fnergy Strategy (TA) } \\
\text { Global Value Chain Analysis }\end{array}$ & & $\begin{array}{l}\text { FY13-16 } \\
\text { FY14-15 } \\
\text { FY15-16 } \\
\text { FY15-17 } \\
\text { FY15-17 } \\
\text { FY15-16 } \\
\text { FY15-16 } \\
\text { FY15-16 } \\
\text { FY15-16 } \\
\text { FY15-16 }\end{array}$ \\
\hline \multirow{2}{*}{$\begin{array}{l}\text { IMF work } \\
\text { program in the } \\
\text { next } 12 \text { months }\end{array}$} & Article IV Consultation & & FY2017 \\
\hline & $\begin{array}{l}\text { Technical Assistance } \\
\text { - } \quad \text { Domestic Revenue Mobilization } \\
\text { - } \quad \text { Public Investment Efficiency } \\
\text { - } \quad \text { Medium-term Expenditure Framework } \\
\text { - } \quad \text { Government Finance Statistics } \\
\text { - } \quad \text { Non-Bank Lenders' Supervision } \\
\text { - Macro-Financial Forecasting } \\
\text { - Macroprodential Supervision } \\
\text { - } \quad \text { Balance of Payment Statistics }\end{array}$ & & FY2017 \\
\hline
\end{tabular}




\section{STATISTICAL ISSUES}

\section{Assessment of Data Adequacy for Surveillance}

General: Data provision is adequate for surveillance, albeit there are some data shortcomings in national accounts, fiscal, monetary, and external sector statistics in terms of accuracy and reliability of the source data and the statistical techniques used in the compilation of national accounts, government finance, and balance of payments statistics.

The timeliness of the central bank survey and detailed government expenditure data by economic classification could be improved to better support economic analysis. Further improvements would include dissemination of readily available information on monthly production of diamonds and quarterly aggregate financial soundness indicators.

The authorities are working on a number of fronts to improve data quality and dissemination: (i) source data and methodologies are being reviewed for those data with obvious estimation problems/gaps, (ii) stronger collaboration is being sought among source data producers to secure consistency and reconcile discrepancies across data sets; (iii) the production of leading economic indicators is currently underway; and (iv) staff shortages are being addressed.

National Accounts: In October 2012, Statistics Botswana (SB) announced revised time series of GDP rebased to 2006 as a new benchmark year. In addition, SB revised the national accounts in 2015 to include new mines in the GDP estimates. With this correction, the 2013 real growth rate has been revised upwards to 9.9 percent from the previous value of 5.9 percent. There are some areas for further improvements, which include representativeness of the coverage of national accounts surveys and estimations of the GDP deflators. In addition, more frequent household surveys (the last conducted in FY 2009/10) would help improve data on poverty, income, and unemployment.

Price Statistics: The monthly consumer price index (CPI) is available on a timely basis in the SB's website. The index is comprehensive and provides breakdowns between urban and rural price data and between prices of tradable and non-tradable goods and services. Currently SB is working to update the CPI weights based on the recent Household Income and Expenditure Survey. Compilation challenges include the eventual inclusion of owner-occupied housing price data in the CPI. The compilation of producer or wholesale prices has been discontinued.

Government Finance Statistics: The concepts and definitions used in compiling government finance statistics generally follow the guidelines of the IMF's 1986 Government Finance Statistics Manual (GFSM 1986) but cover only budgetary central government activities. No fiscal statistics are compiled for extra budgetary institutions, consolidated central government, or consolidated general government. No decision has been made on a "migration path" to the GFSM 2001 methodology, although the authorities are working with the Statistics Department toward that endeavor. Recurrent and development expenditure data are published with a significant lag, while development spending comprises a mixture of current and capital spending.

Monetary and Financial Statistics: Compilation practices are consistent with the Fund's Monetary and Financial Statistics Manual. The central bank survey is currently available with a lag of usually about three months, which is well short of the two-week period recommended in the SDDS. STA's recommendation is to make preliminary data available with clear identification of data status. The authorities prefer a 
more cautious approach to data dissemination to avoid reputation damage if the data require revisions. The $B o B$ is seeking to expand the coverage of financial statistics to include the operations of nonbank financial intermediaries (NBFI), such as pension funds, insurance companies, and other financial corporations, such as unit trusts, finance companies, and financial auxiliaries. STA's recommendation is to focus on data collection in a handful of large institutions within each NBFI category.

Balance of Payments and International Investment Position Statistics: Annual and quarterly balance of payments data are published in the Botswana Financial Statistics (BF) and the BoB's Annual Report. Preliminary data are generally disseminated within two months of the end of the reporting period, while revised (final) data are available after nine months. The concepts, structure, and definitions of the balance of payments statistics follow the fifth edition of the Balance of Payments Statistics Manual (BPM5). Source data are broadly adequate, but the International Transaction Reporting System (ITRS) data-as opposed to alternative survey data on services and transfer items in the current account-has become unreliable. Data compilation, estimation, and adjustments mostly employ sound techniques, but the methods used for estimating missing data (for example, unrecorded trade), f.o.b. /c.i.f. adjustment factors to import values, and flows from stock data are inadequate. Discrepancies exist in trade statistics data concerning: (i) the valuation of diamond exports and imports and (ii) imports, exports, and payments related to settlements within the Southern African Customs Union (SACU). Following the relocation of De Beers' London operations, the compilation challenges associated with the appropriate treatment of diamond related re-export trade emerged both in the national accounts and balance of payments. These problems are likely behind large errors and omissions.

The BoB conducts an annual survey of Botswana's investment and international investment position (IIP). A quarterly IIP survey is also produced for internal use with data from the ITRS.

\section{Data Standards and Quality}

Botswana was the first country to implement the Enhanced General Data Dissemination System (e-GDDS) in January 2016. Essential macroeconomic data are available through the National Summary Data Page (NSDP), currently on the central bank website, utilizing the Open Data Platform installed with the support of the African Development Bank. A Data ROSC and its updates were published in April 2002, March 2004, and April 2007, respectively.

\section{Reporting to STA}

Monetary data are reported for publication in International Financial Statistics using Standardized Report Forms and Botswana reports annual balance of payments and IIP data to STA. No government financial statistics are currently reported for publication in the Government Finance Statistics Yearbook. 


\begin{tabular}{|c|c|c|c|c|c|c|c|}
\hline \multicolumn{8}{|c|}{$\begin{array}{l}\text { Botswana: Common Indicators Required for Surveillance } \\
\qquad \text { (As of March 1, 2016) }\end{array}$} \\
\hline & \multirow{2}{*}{\begin{tabular}{|c|}
$\begin{array}{c}\text { Date of } \\
\text { Latest } \\
\text { Observation }\end{array}$ \\
\end{tabular}} & \multirow{2}{*}{$\begin{array}{c}\text { Date } \\
\text { Received }\end{array}$} & \multirow{2}{*}{$\begin{array}{l}\text { Freq. of } \\
\text { Data }^{1}\end{array}$} & \multirow{2}{*}{\begin{tabular}{|l|} 
Freq. of \\
Reporting
\end{tabular}} & \multirow{2}{*}{$\begin{array}{c}\text { Freq. of } \\
\text { Publication }\end{array}$} & \multicolumn{2}{|c|}{ Memo Items } \\
\hline & & & & & & \begin{tabular}{|l|} 
Data Quality- \\
Methodological \\
Soundness
\end{tabular} & $\begin{array}{l}\text { Data Quality- } \\
\text { Accuracy and } \\
\text { Reliability }\end{array}$ \\
\hline Exchange rates & Mar, 2016 & $3 / 14 / 2016$ & D & D & D & & \\
\hline $\begin{array}{l}\text { International reserve assets and reserve } \\
\text { liabilities of the monetary authorities }{ }^{4}\end{array}$ & Dec, 2015 & $3 / 1 / 2016$ & M & M & M & & \\
\hline Reserve/base money & Dec, 2015 & $3 / 1 / 2016$ & M & M & M & O, O, LO, O & $\begin{array}{l}\text { LNO, O, LO, LO, } \\
\text { LO }\end{array}$ \\
\hline Broad money & Dec, 2015 & $3 / 1 / 2016$ & M & M & M & & \\
\hline Central bank balance sheet & Dec, 2015 & $3 / 1 / 2016$ & M & M & M & & \\
\hline $\begin{array}{l}\text { Consolidated balance sheet of the } \\
\text { banking system }\end{array}$ & Dec, 2015 & $3 / 1 / 2016$ & M & & M & & \\
\hline Interest rates ${ }^{5}$ & Dec, 2015 & $3 / 1 / 2016$ & M & M & M & & \\
\hline Consumer price index & Jan, 2016 & $2 / 1 / 2016$ & M & M & M & $\mathrm{O}, \mathrm{LO}, \mathrm{O}, \mathrm{O}$ & LO, LO, LO, LO, O \\
\hline $\begin{array}{l}\text { Revenue, expenditure, balance, and } \\
\text { composition of financing }{ }^{6} \text {-general } \\
\text { government }{ }^{7}\end{array}$ & NA & NA & & & & LO, LNO, LNO, LO & $\begin{array}{l}\text { LO, O, LO, LO, } \\
\quad \text { LNO }\end{array}$ \\
\hline $\begin{array}{l}\text { Revenue, expenditure, balance, and } \\
\text { composition of financing }{ }^{6} \text {-central } \\
\text { government }\end{array}$ & Oct, 2015 & Feb-16 & $\mathrm{A} / \mathrm{Q} / \mathrm{M}$ & Q & Q & & \\
\hline $\begin{array}{l}\text { Stocks of central government and central } \\
\text { government-guaranteed debt }{ }^{8}\end{array}$ & Sep, 2015 & Jan-16 & A & A & A & & \\
\hline External current account balance & 2015Q3 & Jan-16 & $\mathrm{A} / \mathrm{Q}$ & A & A & O, O, O, LO & $\begin{array}{l}\text { LO, LO, LNO, O, } \\
\text { LO }\end{array}$ \\
\hline Exports and imports of goods & 2015Q4 & Feb-16 & M & M & M & & $\begin{array}{l}\text { LO, LO, LNO, LO, } \\
\text { LO }\end{array}$ \\
\hline GDP/GNP & 2015Q3 & Feb-16 & $\mathrm{A} / \mathrm{Q}$ & $\mathrm{A} / \mathrm{Q}$ & $\mathrm{A} / \mathrm{Q}$ & LO, LO, LNO, LO & \\
\hline Gross external debt & 2015Q2 & Dec-15 & $\mathrm{A} / \mathrm{Q}$ & A & A & & \\
\hline \multicolumn{8}{|c|}{$\begin{array}{l}{ }^{2} \text { Reflects the assessment provided in the data ROSC published on April 6, 2007, and based on the findings of the mission that took place in October- } \\
\text { November 2006, for the data set corresponding to the variable in each row. The assessment indicates whether international standards concerning } \\
\text { (respectively) concepts and definitions, scope, classification/sectorization, and basis for recording are fully observed (O), largely observed (LO), largely not } \\
\text { observed (LNO), not observed (NO), or not available (NA). }\end{array}$} \\
\hline \multicolumn{8}{|c|}{$\begin{array}{l}{ }^{3} \text { Same as footnote } 2 \text {, except referring to international standards concerning (respectively) source } \\
\text { assessment and validation of intermediate data and statistical outputs, and revision studies. }\end{array}$} \\
\hline \multicolumn{8}{|c|}{${ }^{4}$ Includes reserve assets pledged or otherwise encumbered as well as net derivative positions. } \\
\hline \multicolumn{8}{|c|}{${ }^{5}$ Both market-based and officially determined, including discount, money market, treasury bill, no } \\
\hline \multicolumn{8}{|c|}{${ }^{6}$ Foreign, domestic bank, and domestic nonbank financing. } \\
\hline \multicolumn{8}{|c|}{$\begin{array}{l}7 \text { The general government consists of the central government (budgetary funds, extra budgetary funds, and social security funds) and state and local } \\
{ }^{8} \text { Including currency and maturity composition. }\end{array}$} \\
\hline
\end{tabular}

\section{CInternational Monetary Fund. Not for Redistribution}




\section{Statement by Ms. Kapwepwe, Executie Director for Botswana, Ms. Tshazibana, Alternate Executive Director and Ms. Dlamini-Kunene, Senior Advisor on Botswana March 16, 2016}

Our authorities appreciate the continued engagement with the Fund and thank staff for the constructive discussions during the Article IV mission in Gaborone. They broadly agree with the assessment and conclusions of the staff report. The authorities also concur with the analysis of the challenges facing the country, especially the need to diversify the economy, reduce high unemployment, and manage the size of the public sector.

Prudent macroeconomic management has been key to Botswana's macroeconomic stability and strong economic performance over the years. In addition, economic activity benefited from robust growth in the diamond mining sector. However, the continued weak recovery of the global economy and prolonged depression of commodity prices, especially contraction of the diamond market in 2015, have weakened the domestic economic prospects. The shortage of water and electricity, which are key inputs in driving economic activities, has also undermined domestic growth prospects.

At the same time, the authorities are mindful that reliance on a growth model driven by diamond mining and the public sector has rendered the country vulnerable to adverse shocks. That said, the country has accumulated reasonable buffers which will allow the authorities to cushion the impact of shocks and pursue their development agenda encompassed in their National Development Plan.

\section{Recent Economic Developments}

Economic activity was much weaker in 2015 due to a slowdown in mining output. Based on the third quarter GDP estimates of a 3.5 percent contraction, the GDP estimate for 2015 was revised downward from 2.6 percent to 1.0 percent. A modest recovery is expected, with GDP growth projected at 4.2 percent and 4.3 percent in 2016 and 2017, respectively, underpinned by a rebound in both the mining and non-mining sectors.

Inflationary pressures remained subdued in 2015 benefiting largely from modest demand and lower fuel prices. Fuel prices were adjusted downwards in February, August and December 2015, following a decrease in global crude oil prices. Consequently, the annual inflation rate fell from 3.8 percent at the end of 2014 to 3.1 percent at the end of 2015 . Given the positive inflation outlook, the Bank Rate was reduced by a cumulative 150 basis points to 6.0 percent in 2015. Fuel prices are expected to remain low in 2016, thus exerting downward pressure on domestic prices. 
The current account has improved significantly since the contraction in 2009. However, the surplus is estimated to decrease to P11.3 billion in 2015 from P22.2 billion in 2014 mainly due to lower diamond exports. Gross official reserves increased by 7.3 percent to P84.9 billion in December 2015, equivalent to 19 months of imports cover.

The outlook remains positive, supported by a projected moderate global economic recovery and expected improvements in diamond prices as well as expectations of a positive impact of the authorities' Economic Stimulus Program. However, there are significant downside risks to the outlook, including the uncertain external environment and the sluggish growth projected for South Africa which will have an adverse impact on the Southern African Customs Union (SACU) revenues.

\section{Fiscal policy}

The authorities have pursued sound fiscal policy that has contributed to macroeconomic stability. The current fiscal framework has served Botswana well and the authorities remain committed to their guiding principles, which include expenditure ceiling of 40 percent of GDP. In the aftermath of the global financial crisis, the ratio of expenditure to GDP exceeded the 40 percent limit in 2008/09 and 2009/10. However, the authorities adopted appropriate consolidation measures in the subsequent years, reducing the ratios to be more consistent with the guiding principles of keeping expenditure in line with long-term expected revenue. In turn, Botswana's debt has remained significantly below the target stipulated in legislation.

The fiscal framework has provided the authorities much needed flexibility to implement counter cyclical fiscal policy, to cushion the economy from adverse effects of external shocks. In line with the authorities' objective and given the challenging domestic and external environment, the 2016/17 National Budget envisages continued government investment to address infrastructure challenges, especially for water and electricity, and support growth. The budget deficit is projected at 4 percent of GDP and will be financed by drawing down on government deposits and, foreign and domestic debt issuance. However, efforts will be made to contain expenditure; including reducing the public sector wage bill and improving the efficiency of State-owned Enterprises (SOEs). The authorities will also introduce stricter project appraisal criteria for selection of public investment projects and minimize delays in implementation.

\section{Monetary Policy}

The main objective of monetary policy is price stability. This has contributed to overall macroeconomic stability and supported sustainable economic growth. Restrained inflationary pressures allowed for an accommodative monetary policy stance and monetary policy will remain accommodative in the near term to support growth. The authorities will remain prudent and stand ready to tighten monetary policy should inflationary pressures arise. 


\section{Exchange Rate Policy}

Botswana maintains a crawling peg. The authorities aim to ensure that the domestic currency is valued appropriately and the country remains competitive by maintaining a stable real effective exchange rate (REER). In this context, the annual review of the Pula exchange rate mechanism, which took place in December 2015, maintained the current basket weights of 50 percent South African rand and 50 percent IMF's Special Drawing Rights (SDR). With domestic inflation expected to be on the lower end of the 3-6 percent inflation target range, the rate of crawl was changed from zero in 2015 to an upward rate of 0.38 percent per annum for 2016.

\section{Structural Reforms}

The main challenge for Botswana, as a land-locked country with a very small population and market base, is to reduce the cost of doing business and shift exports from goods to labor intensive services. The current water and electricity shortages have exacerbated the situation by increasing business costs. This has amplified the urgency for the authorities to address the infrastructure bottlenecks and improve efficiencies. In this context, the 2016/17 budget identifies major energy and water infrastructure projects to be implemented over the medium term.

To address unemployment and support a more inclusive growth path, the authorities have prioritized for 2016/2017 fiscal year economic activities with the potential to create employment opportunities. These include improvement and maintenance of the country's road networks, wildlife and tourism initiatives, establishment of special economic zones and continued implementation of the Economic Diversification Drive (EDD) initiatives.

Although the authorities have invested substantial resources in the development of skills for the country's workforce, education outcomes have been declining. To tackle this challenge, in 2015 the authorities adopted the Education and Training Sector Strategic Plan (ETSSP). It is expected that the implementation of the ETSSP will help improve the quality of existing vocational education and training programs and also equip the youth with appropriate skills. In addition, the authorities will continue investing in education and training with emphasis on ensuring that the skills and qualifications offered and acquired are more responsive to the needs of the labor market.

\section{Conclusion}

My authorities will continue to pursue sound macroeconomic policies which have supported economic growth and stability. The prudent management of diamond wealth has placed the authorities in a position to undertake structural reforms to ensure a more inclusive and sustainable economic growth. To do this, bold reforms are needed on infrastructure and human resource development, while minimizing inefficiencies and making certain that the 
projects commenced deliver the intended impact. My authorities believe that saving for the future generation is not just about financial resources; it is also about investing in tangible development and improving efficiency to secure the future generation. Finally, my authorities appreciate the ongoing Fund advice and Technical Assistance. 